Universidade de São Paulo

Escola Superior de Agricultura "Luiz de Queiroz"

Centro de Energia Nuclear na Agricultura

Conservação ambiental em paisagens agrícolas:

relações entre uso da terra e meio ambiente na bacia hidrográfica do Corumbataí,

Estado de São Paulo, Brasil

Fábio Henrique Comin

Tese apresentada para obtenção de título de Doutor em Ciências. Área de concentração:

Ecologia Aplicada

Piracicaba

2013 
Fabio Henrique Comin

Licenciado em Ciências Biológicas

Conservação ambiental em paisagens agrícolas:

relações entre uso da terra e meio ambiente na bacia hidrográfica do Corumbataí, Estado de São Paulo, Brasil

versão revisada de acordo com a resolução CoPGr 6018 de 2011

Orientador:

Prof. Dr. LUCIANO MARTINS VERDADE

Tese apresentada para obtenção de título de Doutor em Ciências. Área de concentração:

Ecologia Aplicada

Piracicaba

2013 
Dados Internacionais de Catalogação na Publicação DIVISÃO DE BIBLIOTECA - ESALQ/USP

Comin, Fábio Henrique

Conservação ambiental em paisagens agrícolas: relações entre uso da terra e meio ambiente na bacia hidrográfica do Corumbataí, Estado de São Paulo, Brasil / Fábio Henrique Comin. - - versão revisada de acordo com a resolução CoPGr 6018 de 2011. - - Piracicaba, 2013.

153 p. : il.

Tese (Doutorado) - - Escola Superior de Agricultura "Luiz de Queiroz". Centro de Energia Nuclear na Agricultura, 2013.

1. Agricultura familiar 2. Bacia hidrográfica 3. Corumbataí 4. Meio ambiente 5. Paisagens agrícolas 6. Proteção ambiental 7. Recursos hídricos 8 . Uso da terra I. Título

CDD 333.91

$\mathrm{C} 733 \mathrm{c}$

"Permitida a cópia total ou parcial deste documento, desde que citada a fonte - 0 autor" 
Aos meus pais Ézio, Cecília e para Carla, dedico. 


\section{Agradeço...}

\section{AgRadeCIMENTOS}

Aos meus pais e toda minha família que ao seu modo me inspiraram e apoiaram sempre.

A Carla, presença constante, companheira de vida, de sonhos, conquistas viagens e aventuras, ao teu lado "...uma parte do mundo é nossa morada a outra parte é nosso quintal".

A todos do Programa de Pós-Graduação PPGI-EA pela oportunidade e a Mara Casarin pelo carinho e ajuda sempre que necessária. A FAPESP, CNPQ, Seção de Pós Graduação e Bibliotecárias da Esalq, pelo apoio.

Aos professores, Silvio Ferraz, Silvia Molina, Ricardo Rodrigues, Paulo Moruzzi, Sérgius Gandolf, Paulo Kageyama, Bill Balé, Weber Amaral, Antônio Almeida, Alexandre Percequillo, Laura Martirani e todos amigos da pós pelo convívio, ensinamentos e boas conversas.

Aos professores Carlos A. Vettorazzi, Dalcio Caron, Oriwaldo Queda, Rodrigo C. Martins, Flavio Gandara, Plinio B. Camargo, Cristina S. Seixas, Patrícia Pinho, Maria Aparecida Lisboa, obrigado pela participação, ensinamentos e colaboração.

Em especial para professora Maria Elisa Garavello, pela acolhida desde o mestrado, participação importante no doutorado, obrigado pelas conversas, pelo apoio e pelo carinho.

Em especial para professora Carla Gheler-Costa, por todas as discussões, sugestões, críticas, leitura criteriosa e ajuda mais do que necessária.

Em especial e com muita estima ao professor e orientador Luciano M. Verdade pelos dez anos de convívio, amizade e sempre me inspirando a trilhar por esse caminho, sei que ainda teremos boas conversas, boas caminhadas e boas histórias pela frente.

A professora Ap. Célia Gheler Costa, pela leitura, correções e sugestões.

Aos agrônomos da casa de agricultura Marcelo de Corumbataí, Mi de Analândia e Luiz de Ipeúna e aos gestores da APA. Em especial a todos os agricultores familiares, pessoas de bem, obrigado pela acolhida e informações cedidas, vocês foram a melhor parte deste trabalho.

Às minhas companheiras de quatro patas Lilei, Lailinha e Doce pelo seu amor incondicional e nossas longas caminhas reflexivas.

Aos amigos de Santa Rita do Passa Quatro, Portugal, Argentina, Acre, Piracicaba, Holambra, Itaqui e Bauru, impossível colocar o nome de todos, mas vocês sabem que tem lugar especial na minha vida e nessa tese. Em especial aos Horríveis do Apocalipse e os Potibikers, nossas pedaladas, conversas e aventuras foram essenciais, fizeram bem para o corpo, mente, espirito, avante e continuemos fraternos. 
"O conhecimento nos faz responsáveis" (Che Guevara) 


\section{SUMÁRIO}

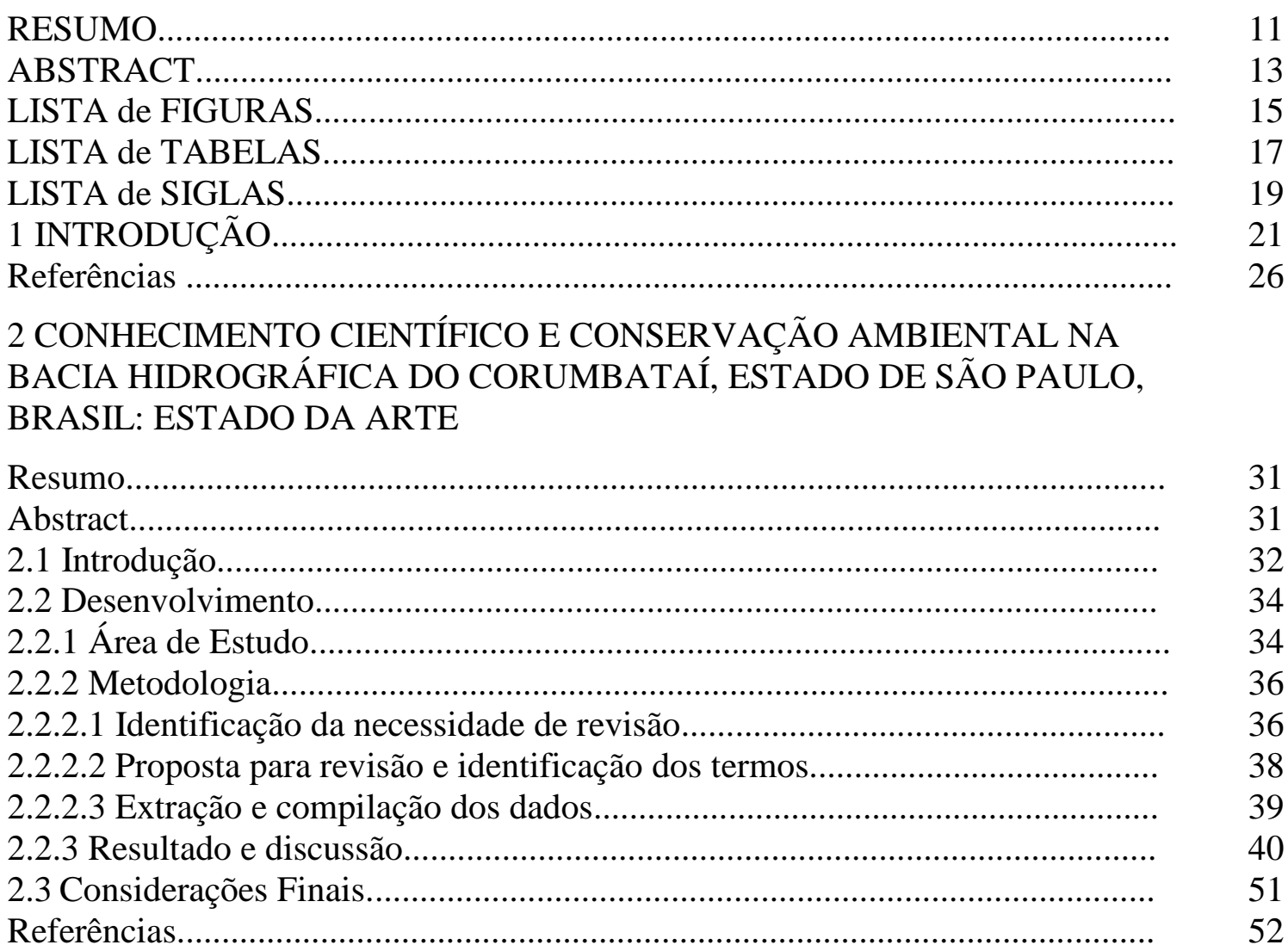

3 RELAÇÃO ENTRE AGRICULTURA FAMILIAR E MEIO AMBIENTE EM PAISAGENS AGRÍCOLAS: ÁREA DE PROTEÇÃO AMBIENTAL DO CORUMBATAÍ, ESTADO DE SÃO PAULO - BRASIL

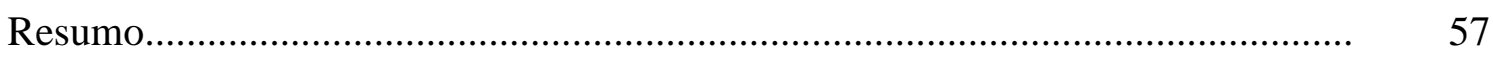

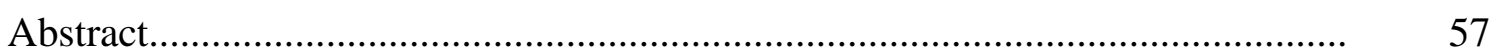

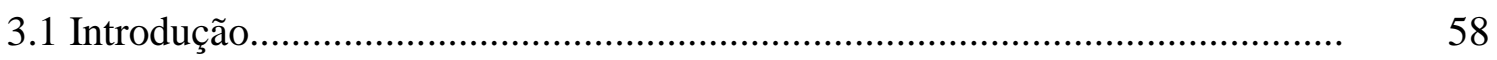

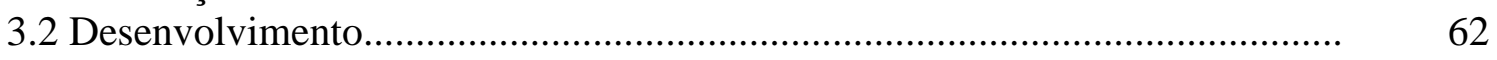

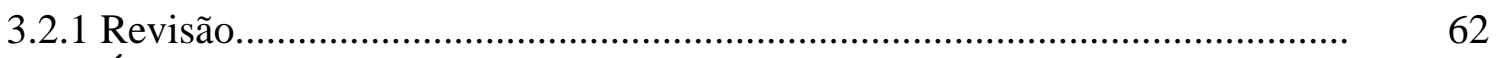

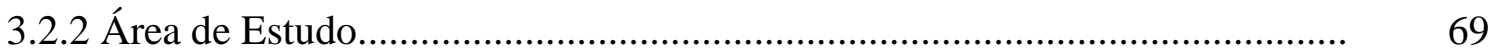

3.2.3 Escolha e definição do público alvo e coleta de dados.................................. 71

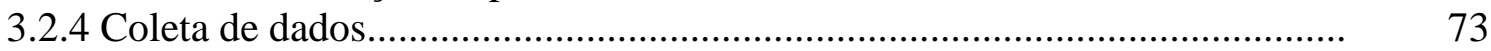

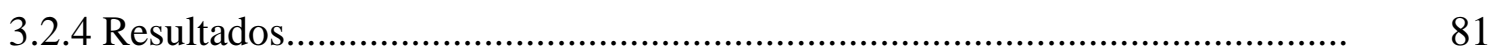

3.2.4.1 Agricultura Familiar na APA............................................................. 81

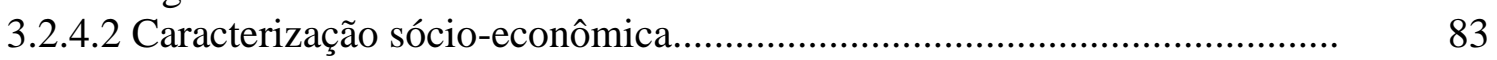

3.2.4.3 Caracterização sócio-ambiental........................................................... 95

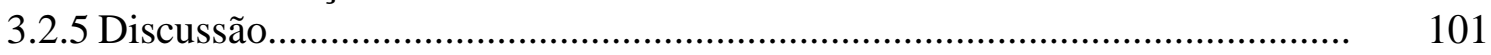

3.3 Considerações Finais.......................................................................... 115

Referências.......................................................................................... 117

4 PERSPECTIVAS INTERDISCIPLINARES PARA CONSERVAÇÃO DE PAISAGENS AGRÍCOLAS NO ESTADO DE SÃO PAULO

Resumo.

Abstract. 


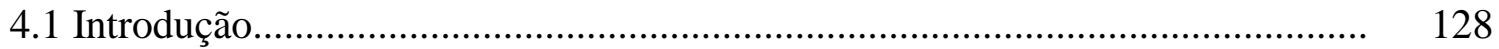

4.2 Desenvolvimento................................................................................. 129

4.2.1 Situação da interdisciplinaridade................................................................... 129

4.2.2 Situação da ciência: diferentes áreas do conhecimento e o projeto 131

interdisciplinar.

4.2.3 Situação do conhecimento: problemas ambientais em paisagens agrícolas

mediante as pesquisas interdisciplinares.

4.2.4 Situação de hoje: o processo interdisciplinar é um método de trabalho.

4.3 Considerações Finais.

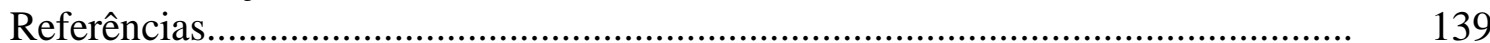

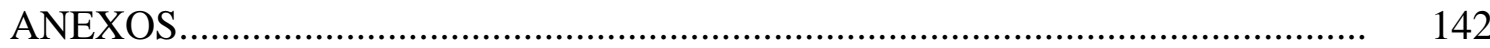




\title{
RESUMO \\ Conservação Ambiental em Paisagens Agrícolas: \\ Relação entre uso da terra e meio ambiente na Bacia Hidrográfica do Corumbataí, Estado de São Paulo, Brasil
}

\begin{abstract}
Historicamente, a produção de alimentos básicos no Brasil está associada à agricultura familiar. Atualmente, vigora um novo olhar sobre essa produção quando entram em cena outros componentes: a produção de commodities e a conservação ambiental. Conflitantes entre si, eles parecem não influenciar diretamente no modo com que a população do meio rural percebe as supostas relações de perdas no meio ambiente ou na biodiversidade. A partir dessas considerações, observamos que na Bacia do Corumbataí, com as mudanças no uso da terra nos últimos trinta anos, a agricultura familiar tem se modificado, assumindo diferentes configurações e variando segundo o tamanho das propriedades, tipos de produções e relações diferenciadas que essas têm com o meio ambiente. Sabemos que a compreensão da dimensão humana promove habilidades para responder à variedade de interesses sociais, científicos e políticos na conservação da natureza. Algumas dessas dimensões são: as atitudes, os valores, o comportamento, as características socioeconômicas, a demografia, entre outras que devem integrar as ciências sociais e a ecologia para a interdisciplinaridade da conservação. É nesse sentido que entendemos que as soluções para a crise de biodiversidade no meio rural serão geradas a partir do trabalho conjunto entre cientistas naturais e sociais em projetos interdisciplinares. Ainda que alguns trabalhos caminhem nesta direção, não existe nos estudos em agroecossistemas da Bacia do Corumbataí uma ponte que una componente humano e conservação. Para a região estudada, não há, a priori, respostas para estas questões, mas acreditamos que o desafio em conservar a biodiversidade está no balanço entre as metas ecológicas e as necessidades sociais, econômicas e políticas, havendo urgência na integração entre a comunidade local, pesquisadores e governança. Em termos de Bacia hidrográfica, a do Corumbataí é uma das regiões mais estudadas do meio científico, mas todo conhecimento gerado pouco tem contribuído para a conservação com vista à sustentabilidade tanto ambiental, quanto social. Portanto, o processo e construção de diálogo entre disciplinas firmemente estabelecidas na sua identidade teórica e metodológica, foi definitivamente nossa vocação neste trabalho. À luz dessas considerações, podemos sustentar que a atividade, o conhecimento e a vivência do pequeno produtor rural são de fundamental importância para a sua manutenção no campo, bem como para a pesquisa e a própria conservação dos recursos naturais na região. Os resultados desta tese apontam que as pesquisas de interação social e ambiental, tendo como agente facilitador à agricultura familiar geram perspectivas reais para desenvolvimento social e para conservação ambiental local.
\end{abstract}

Palavras-chave: Corumbataí; Paisagens agrícolas; Agricultura familiar; Recursos hídricos 


\section{ABSTRACT \\ Environmental Conservation and Agricultural Landscapes: Relationship between land use and environment in Corumbataí Watershed, São Paulo State, Brazil.}

Currently we have a new look on production, when other components such as the production of commodities and environmental conservation come into this scenario. Dichotomous each other, they do not seem to directly influence the way the rural population notice the alleged loss relationships in the environment or biodiversity. From these considerations we see that the Corumbataí basin with changes in land use over the last thirty years, the family farm has changed, assuming different configurations and varying according to the size of the properties, types of productions and different relationships between them and the environment. We know that understand the human dimension promotes skills to respond to the variety of social, scientific and political interests in nature conservation. Some of these dimensions are: the attitudes, valuesbehaviour, socioeconomic characteristics, demography, among others that must be included in the social sciences and ecology to a interdisciplinary conservation. That is why we believe that the solutions to the biodiversity crisis in rural areas will be generated from a combined work between natural and social scientists in interdisciplinary projects. Although some works walk in that direction, in agroecosystems studies in the Corumbataí basin there is not a bridge that join the human component and conservation. For the studied area, there are no a priori answers to these questions, but we believe that the challenge in biodiversity conservation is in the ecological balance between the goals and the social, economic and political needs, with urgency in the integration between the local community, researchers and governance. In terms of watershed, the Corumbataí basin is one of the most studied regions, but all knowledge generated has little contribution to the conservation for environmental and social sustainability. Therefore, the process and construction of the dialogue between disciplines firmly established in its theoretical and methodological identity was definitely our vocation in this work. So we hold that the activity, knowledge and experience of small farmers are essential to their maintenance in the field, as well as for research and self-preservation of natural resources in the region. The results of this thesis suggest that studies of environmental and social interaction, with as facilitator a family farms, generate real prospects for social development and environmental conservation site.

Keywords: Corumbataí; Agricultural landscapes; Family farming; Water resources 


\section{LISTA DE FIGURAS}

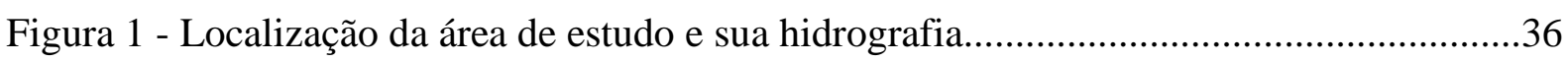

Figura 2 - Evolução da produção bibliográfica por década na Bacia do Corumbataí................40

Figura 3 - Índice de frequência de registros em relação às palavras-chave de maior

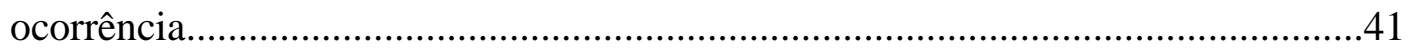

Figura 4 - Número de registros encontrados nos bancos de dados analisados.........................41

Figura 5 - Número de registros no cenário nacional: a) Biblioteca Digital Brasileira de Teses e Dissertações; b) Biblioteca da Empresa Brasileira de Pesquisa

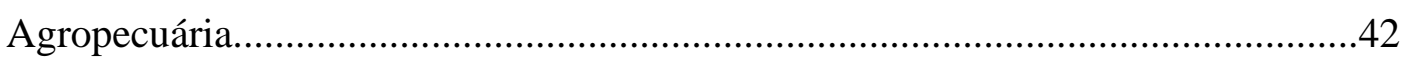

Figura 6 - Número de registros encontrados no cenário estadual: a) Biblioteca Digital da USP; b) Biblioteca Digital da UNESP; c) Biblioteca Digital da UNICAMP; d) Biblioteca Digital da UFSCar.

Figura 7- Número de registros encontrados em bancos de dados referentes a publicações científicas: a) Periódicos CAPES; b) Periódicos SCIELO; c) Web of Science; d) SCOPUS.

Figura 8 - Índice de frequência de registros em relação às grandes áreas de pesquisas realizadas na Bacia do Corumbataí........................................................................46

Figura 1 - Bacia do Corumbataí, evidenciando a APA do Corumbataí....................................71

Figura 2 - Unidades produtivas da Agricultura Familiar visitadas na APA Corumbataí..........83

Figura 3 - Distribuição das propriedades visitadas em função da área....................................84

Figura 4 - Relação entre área e renda em salários mínimos mensais (A) e entre área, renda e

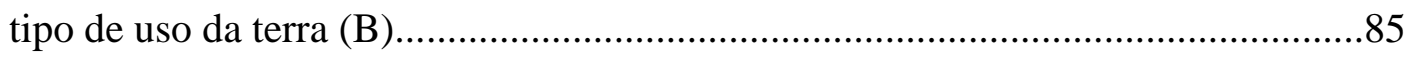

Figura 5 - Relação entre tamanho da propriedade e diversidade agrícola..............................91

Figura 6 - Unidades produtivas visitadas e sua relação com a hidrografia..............................96

Figura 7 - Distribuição dos pontos de coleta sobrepostos às microbacias consideradas prioritárias para restauração florestal proposto por Ferraz et al. (2009) (Figura

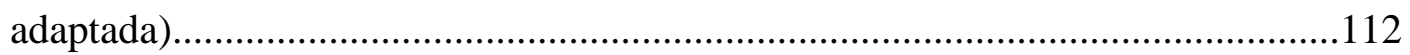

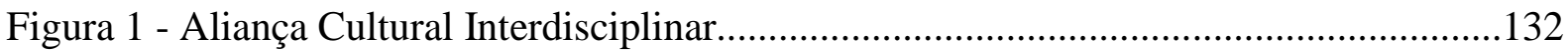




\section{LISTA DE TABELAS}

Tabela 1 - Informações sobre propriedades rurais nos municípios estudados . .72

Tabela 2 - Tabela exemplo de sistematização e compilação de dados. .76

Tabela 3 - Unidades produtivas por município estudado (*Imóveis rurais cadastrados no Sistema Nacional de Cadastro Rural - Índices Básicos 2005 - INCRA - Base de Abril 2007, ** População Rural nos Municípios Estudados (Fonte: FUNDAÇÃO SEADE, 2010))

Tabela 4 - Resgate e listagem livre dos itens para autoconsumo e comércio nas unidades produtivas..... . .92

Tabela 5 - Informações gerais a respeito dos recursos hídricos nas propriedades amostradas.97 


\section{LISTA DE SIGLAS}

APA - Área de Proteção Ambiental

APP - Área de Preservação Permanente

BHC - Bacia Hidrográfica do Rio Corumbataí

Biota-FAPESP - Programa de Pesquisa em Caracterização, Conservação, Recuperação e Uso Sustentável da Fundação de Amparo a Pesquisa no Estado de São Paulo

CAPES - Coordenação de Aperfeiçoamento de Pessoal de Nível Superior

CATI - Coordenadoria de Assistência Técnica Integral

CBH - Comitê de Bacia Hidrográfica

CETESB - Companhia Ambiental do Estado de São Paulo

FAO - Food and Agriculture Organization

IBGE - Instituto Brasileiro de Geografia e Estatística

INCRA - Instituto Nacional de Colonização e Reforma Agrária

IPEF - Instituto de Pesquisa e Estudos Florestais

ONG - Organização Não Governamental

CBHPCJ - Comitê da Bacia Hidrográficas dos Rios Piracicaba, Capivari e Jundiaí

SNUC - Sistema Nacional de Unidades de Conservação

UC - Unidade de Conservação

UFSCar - Universidade Federal de São Carlos

UNESP - Universidade Estadual Paulista

URGGHI - Unidade de Gerenciamento de Recursos Hídricos

USP - Universidade de São Paulo 


\section{INTRODUÇÃO}

Este é um estudo de caráter interdisciplinar que trata da conservação da biodiversidade em paisagens agrícolas, entendendo a relação entre o papel das pesquisas ambientais e a vulnerabilidade da agricultura familiar na Bacia Hidrográfica do Corumbataí, Estado de São Paulo, Brasil. Desde o início do século 19, a agricultura praticada na região da Bacia do Corumbataí foi do tipo predatória. Segundo Warren Dean, “os colonizadores nessa região abriam clareiras temporárias na floresta por meio do fogo para cultivo principalmente de milho, cana de açúcar ou pastagens para o gado" (DEAN, 1977). Já no tecnificado século 21, não só o fogo como outras ações como mineração, práticas agrícolas inadequadas, poluição ou mesmo o descumprimento das leis ambientais ainda comprometem não somente a biodiversidade, como na figura do pequeno produtor rural a sóciodiversidade regional.

De modo geral, as mudanças no uso e cobertura da terra estão entre as maiores forças causadoras de alterações ambientais em todo o mundo. Portanto, a agricultura ainda é uma das atividades humanas que mais impacto causa em ambientes naturais, seja pela destruição de habitats, pela introdução de espécies, ou pela poluição (TURNER; MEYER, 1994). Segundo Geist e Lambim (2002), as ações antrópicas também causam danos indiretos aos recursos naturais, sendo estes baseados em fatores econômicos, políticos, tecnológicos, culturais e demográficos. Dentro deste contexto, o homem tem sido o principal responsável pelas alterações nas paisagens e nos ecossistemas, sendo, primordiais os estudos que busquem compreender a relação causa/efeito dos processos de degradação e/ou conservação ambiental dos recursos naturais na paisagem agrícola da Bacia do Corumbataí. Para Cullen Jr. et al. (2000), o tipo de vizinhança e uso da terra podem afetar profundamente a diversidade biológica, os processos ecológicos e a conservação. No entanto, na Bacia do Corumbataí pouco se sabe sobre a população rural e como esta se relaciona com a natureza. Portanto, de forma geral este estudo busca elementos para o entendimento da relação entre sociedade e natureza em paisagens agrícolas, tratando da questão socioambiental numa paisagem onde o homem tem o papel de usuário, administrador e mantenedor da biodiversidade.

Segundo os dados do Instituto Brasileiro de Geografia e Estatística - IBGE (2010), a população rural na região que compõe a Bacia do Corumbataí tem diminuído nos últimos dez anos, impulsionada pela falta de incentivos rurais, endividamento e atração por empregos na cidade. Segundo Fuini (2008), há uma estagnação na renda salarial média da mão-de-obra empregada das indústrias na região, o que acaba gerando um quadro de maior dificuldade e pobreza nas cidades, contribuindo ainda mais para o enfraquecimento e desaparecimento dos 
pequenos proprietários rurais na Bacia do Corumbataí, que ainda enxergam as cidades como uma possibilidade na melhoria de qualidade de vida.

O presente estudo inseriu o agricultor familiar nas questões da conservação ambiental da paisagem agrícola, por entender que não há conservação ambiental sem conservação social. Trata-se de um estudo de visão ecológica e social integradas, que busca o entendimento de como as práticas sociais e econômicas dos agricultores, que permanecem na terra, relacionam-se com as questões de cunho ambiental com vistas à conservação ambiental. O antagonismo nesta pesquisa ocorre, primeiro, porque nas últimas décadas a região do Corumbataí sofreu alterações no uso da terra, passando por mudanças nas práticas de produção agrícola de pequena escala, para prática de uma agricultura voltada ao chamado “agronegócio". Segundo, porque ao mesmo tempo em que ocorreram as mudanças na paisagem decorrentes de um sistema agrário voltado para a produção de commodities, aumentaram também a relevância das questões ambientais, e a região tornou-se palco para inúmeras investigações científicas de cunho ambiental, relacionadas à conservação da biodiversidade e recursos hídricos.

Desde a década de 1980, na Bacia Hidrográfica do Corumbataí, têm sido realizadas investigações científicas, principalmente voltadas para a conservação da biodiversidade e questões hídricas. As investigações da problemática ambiental ao longo dos últimos 30 anos devem-se principalmente à adoção do modelo francês de governanças das águas, baseado no modelo de gestão por Bacias Hidrográficas (ESPINOZA; MARTINS, 2011), revelando-se assim, um avanço e um espaço ideal para a pesquisa cientifica nessa região, que podem fortalecer as políticas de gestão.

Muitos dos estudos realizados na Bacia Hidrográfica têm contribuído para identificação, classificação e caracterização de espaços frágeis com fins conservacionistas, principalmente no que se refere aos atributos hídricos. Contudo, a aplicabilidade desses estudos ao longo de quase três décadas, aparentemente, não tem contribuído para o campo das decisões políticas, haja visto que a região vem sofrendo com poluição, desmatamento e êxodo rural (MORAIS et al., 2012; MINGOTI; VETORAZZI, 2011; ANTONIAZZI, 2008; JARDIM et al., 2008; NOBRE, 2008; BORGES et al., 2008; ARMAS et al., 2007). O resultado desta degradação socioambiental contrapõe-se à racionalidade científica que está instaurada na Bacia e, portanto, passível de interpretações críticas, principalmente como forma norteadora de políticas sócio-ambientais (LEFF, 2006).

Alguns estudos em ecologia têm apontado para um novo paradigma na conservação ambiental nas paisagens agrícolas, e reconhecem a necessidade de "olhar para o todo" e não 
somente para questões isoladas ou específicas de cada área do conhecimento (JOLY et al., 2010; PERFECTO et al., 2009). Cerca de oitenta por cento da matriz agrícola do estado de São Paulo é mantenedora de biodiversidade meritória de esforços conservacionistas. Especificamente, na Bacia do Corumbataí, os trabalhos de Gheler-Costa et al. (2012) e, Dotta e Verdade (2007, 2009, 2011), demonstram que não somente os fragmentos florestais, os recursos hídricos, a matriz agrícola ou áreas prioritárias para conservação da biodiversidade devem ser priorizados nas pesquisas científicas, principalmente na região, mas sim, todos os processos de uso e ocupação da terra, pois estes processos se manifestam e influenciam na biota local. Este axioma permite, então, que lancemos mão de outros questionamentos dos quais outros conhecimentos serão construídos, o que implica em reconhecer que a ausência dos estudos sócio-ambientais na Bacia, não somente restringe, mas compromete a tão preconizada conservação ambiental. Investigar tal questão é entender, que em um território socialmente ocupado, seus moradores são protagonistas no processo de gestão e conservação da biodiversidade, e é isso que acentua a necessidade da investigação científica direcionada para as relações e interações entre sociedade e natureza, que por sua vez, contribui para instituição de políticas socioambientais, como por exemplo, pagamentos por serviços ecossistêmicos, poluidor pagador e/ou produtor recebedor.

As discussões entre conservação e desenvolvimento rural, atualmente em voga na literatura científica, referentes às relações sociedade/natureza tem tido muita ressonância em estudos rurais, especificamente da agricultura sustentável (ZANONI, 2000), de sistemas agroecológicos (ALTIERI, 2001; CAPORAL, 2009), ou assentamentos rurais (FERRANTE; WHITAKER, 2009; BERGAMASCO et al., 2003). Schneider (2009, p. 20), atenta, que foi a partir da década de 1990, que a pesquisa do que ele chama de rural lato sensu ganhou força nos debates acadêmicos com a temática ambiental e da sustentabilidade. Um bom exemplo de estudos com essa magnitude foi o seminário internacional sobre ruralidades, trabalho e meio ambiente realizado pela Universidade Federal de São Carlos em 2011, onde trinta e oito trabalhos, num universo de oitenta e três, abordaram a temática sociologia rural e meio ambiente. Neste sentido, este estudo insere-se nesta seara e trata da população rural, suas características socioeconômicas, suas práticas agrícolas e suas supostas relações com o meio ambiente.

Referente ao componente social foi realizado trabalho de campo com os proprietários rurais da Bacia do Corumbataí, com a proposta de verificar suas características socioeconômicas e socioambientais. O público alvo foram os moradores tidos como agricultores familiares que, para Lamarche (1993), "são dotados de enorme capacidade de 
adaptação aos diferentes ambientes históricos e conjunturais”, e que, segundo Silva (1999), cuja agricultura praticada por eles é cada vez mais intensiva, especializada e causa graves problemas ambientais. Já Martins (2006), quando analisa Candido (2001), sobre as transformações no meio de vida do caipira paulista considera que, neste grupo, a tecnologia e as práticas produtivas estão articuladas com o meio ambiente, gerando uma identidade e aproximação com os recursos naturais e práticas de manejo dos ecossistemas. Portanto, a agricultura familiar emerge como objeto de pesquisa por suas relações serem subjacentes à conservação ambiental na Bacia do Corumbataí.

A premissa deste estudo é que na Bacia Hidrográfica do Corumbataí existe uma lacuna muito grande entre as pesquisas conservacionistas em paisagens agrícolas e a falta de pesquisa com os atores sociais que nela residem e usam esta mesma paisagem. Diante disso, as seguintes hipóteses foram testadas: a) Dimensões humanas são em geral desconsideradas em pesquisa sobre a questão ambiental em paisagens agrícolas; e, b) A relação entre os pequenos proprietários e o ambiente não leva em conta a conservação dos recursos hídricos nem as áreas de preservação permanente e de reserva legal. Para tanto os objetivos deste estudo foram: a) Levantar a pesquisa ambiental existente na região; b) Descrever a relação entre os pequenos proprietários e o ambiente na Bacia do Corumbataí; c) Entender os processos de conservação da paisagem agrícola e a contribuição da agricultura familiar sob a luz das pesquisas socioambientais; e d) Refletir sobre o modelo de conservação ambiental em paisagens agrícolas, partindo de um modelo de pesquisa de conteúdo interdisciplinar.

Mediante revisão e leitura criteriosa de trabalhos científicos, subsidiadas por dados secundários disponíveis sobre a região, além do trabalho de campo com agricultores familiares, desencadearam-se diálogos de saberes e articulações na construção dos conhecimentos ambientais para a conservação de paisagens agrícolas no Estado de São Paulo, especificamente para a Bacia do Corumbataí. Nesse sentido, assume-se então o papel relevante das dimensões humanas na conservação da biodiversidade em paisagens agrícolas, já que, mesmo havendo inúmeros estudos em diferentes temas realizados na Bacia, a condição ambiental e social da mesma não tem melhorado e o presente estudo vem corroborar com essas evidencias (ARMAS et al., 2005; ARMAS et al., 2007; BORGES et al., 2008; CETRA; PETRERE, 2006; DOTTA; VERDADE, 2007, 2009, 2011; FALQUETO, 2008; FERRAZ et al., 2009; GHELER-COSTA et al., 2012; GOMIERO; BRAGA, 2006; JARDIM et al., 2008; LIMA-JUNIOR et al., 2006; MESSIAS, 2008; MINGOTI; VETTORAZZI, 2011; MORAIS et al., 2012; PALMA-SILVA et al., 2007; TAUK-TORNISIELO, 2011; VALENTE; VETTORAZZI, 2008). 
Algumas análises deste diagnóstico feito com os agricultores familiares foram embasadas nos critérios da multifuncionalidade, que se refere ao conjunto de serviços e produtos criados pela atividade agrícola, e que têm impacto direto ou indireto sobre a economia, a sociedade e a natureza (BONNAL et al., 2003). A adoção de análise da multifuncionalidade implica em reconhecer as funções econômicas, ambientais e sociais da agricultura familiar na Bacia, além de possibilitar o entendimento das dimensões humanas relativas às estratégias de reprodução social e conservação ambiental. Todavia, segundo Maluf (2003), a multifuncionalidade ambiental na maioria das vezes é desconsiderada pelos analistas do meio rural. Segundo Wanderley (2003, p. 09), ao romper com a hegemonia exclusiva da "função" econômica, o enfoque multifuncional da unidade produtiva pode propiciar o entendimento do agricultor em suas complexas relações com a natureza. Assim, a ênfase dada à multifuncionalidade da agricultura familiar e suas relações com o ambiente, também pode fortalecer a conservação dos recursos naturais na região. Portanto, neste trabalho as considerações sobre a multifuncionalidade ambiental da agricultura familiar pode representar uma tentativa de reconhecer as unidades produtivas, não apenas como produtoras de bens agrícolas ou sociais, mas se ampliam também para o campo de suas funções ambientais, tendo em vista, a conservação ambiental da Bacia. Sugerimos, portanto, que a partir dos dados obtidos é possível desenvolver um campo teórico sobre a multifuncionalidade ambiental da agricultura familiar na paisagem agrícola, como forma de entendimento da dinâmica da população rural em face da conservação da natureza, sendo estes os pilares que sustentam a proposta interdisciplinar deste estudo.

O arcabouço teórico e conceitual deste estudo abrange três níveis de discussão: ambiental, por tratar de conservação da biodiversidade; social, por ter como público investigado agricultores familiares; e acadêmico, sob o aspecto da pesquisa científica relacionada à conservação e aos serviços ambientais.

Este estudo está organizado em três capítulos. O primeiro capítulo, de revisão, é referente ao arcabouço teórico das publicações científicas na região de estudo entre 1950 e 2012. O segundo capítulo, prático, descreve a situação analisada no trabalho de campo, explica o caso estudado na APA do Corumbataí, e caracteriza a relação da agricultura familiar com o uso da terra e o meio ambiente na paisagem agrícola. O terceiro capítulo, conceitual, é um estudo que, sob a luz da interdisciplinaridade, assume o modelo técnico-científico interdisciplinar como uma tendência dos estudos de pesquisas conservacionistas em paisagens agrícolas. 
Por fim, este estudo tem fortes ligações com a proposta multidisciplinar do Programa de Pós-Graduação em que está inserido, com o projeto temático de pesquisa "Mudanças Sócio-ambientais no Estado de São e Perspectiva para Conservação" (Biota/FAPESP) do qual faz parte, além da própria formação e trajetória interdisciplinar do pesquisador. Assim, o presente estudo alia de forma ampla as ciências da natureza com as ciências da sociedade. Nesta perspectiva sugere que seja este o ideário que a pesquisa interdisciplinar de caráter conservacionista em paisagens agrícolas tende a exigir.

\section{Referências}

ALTIERI, M.A. Agroecologia: a dinâmica produtiva da agricultura sustentável. 3. ed. Porto Alegre: UFRGS, 2001. 110p. (Síntese Universitária, 54).

ANTONIAZZI, L.B. Oferta de serviços ambientais na agricultura. 2008. 91p. Dissertação (Mestrado em Economia Aplicada) - Escola Superior de agricultura "Luiz de Queiroz", Universidade de São Paulo, Piracicaba, 2008.

ARMAS, E.D.; MONTEIRO, R.T.R.; AMÂNCIO, A.V.; CORREA, R.M.L.; GUERCIO, M.A. Uso de agrotóxicos em cana-de-açúcar na bacia do Rio Corumbataí e o risco de poluição hídrica. Química Nova, São Paulo, v.28, n.6, p.975-982, 2005.

ARMAS, E.D.; MONTEIRO, R.T.R.; ANTUNES, P.M.; SANTOS, M.A.P.F.; CAMARGO, P.B. Diagnóstico espaço-temporal da ocorrência de herbicidas nas águas superficiais e sedimentos do rio Corumbataí e principais afluentes. Química Nova, São Paulo, v.30, n.5, p.1119- 1127, 2007.

BERGAMASCO, S.M.P.P.; COSTA, C.M.O. Processus d`organization de la prodution dans le assentamentos. Cahiers du Bresil Contemporain, Paris, v. 1, n. 1, p. 51-52, 2003.

BONNAL, P. ; PIRAUX, M. ; FUSILLIER, J.L.; GUILLUY, D. Approche de la multifonctionnalité de l'agriculture à la Réunion: les modèles agricoles, la relation agriculture-emploi et la perception des CTE par les acteurs locaux. Paris : MAAPAR et CIRAD, 2003. 68p.

BORGES, A.K.P.; TAUK-TORNISIELO, S.M.; DOMINGOS, R.N.; ANGELIS, D.F. Performance of the constructed wetland system for the treatment of water from the Corumbataí River. Brazilian Archives of Biology and Technology, Paraná, v.51, n.6, p.1279-1286, 2008.

CANDIDO, A. Os parceiros do Rio Bonito: estudo sobre o caipira paulista e a transformação dos seus meios de vida. 34.ed. São Paulo: Duas Cidades, 2001. 376p.

CAPORAL, F.R. Agroecologia: uma nova ciência para apoiar a transição a agriculturas mais sustentáveis. Brasília: Imprenta, 2009. 30p. 
CETRA, M.; PETRERE Jr., M. Fish-assemblage structure of the Corumbataí river basin, São Paulo State, Brazil: characterization and anthropogenic disturbances. Brazilian Journal of Biology, São Carlos, v.66, n.2a, p.431-439, 2006.

DEAN, W. Rio Claro: um sistema brasileiro de grande lavoura - 1820-1920. Rio de Janeiro: Paz e Terra, 1977. 205p.

DOTTA, G .; V ERDADE, L.M. Felids in an agricultural landscape in São Paulo Brazil. Cat News, London, v. 51, n. 6, p.24-27, 2009.

DOTTA, G. ; VERDADE, L.M. T rophic categories in a mammal assemblage: diversity in an agricultural landscape. Biota Neotropica, São Paulo, v.7, n. 2, p. 287-292, 2007.

DOTTA, G.; VERDADE, L.M. Medium to large-sized mammals in agricultural landscapes of South-eastern Brazil. Mammalia, Paris, v. 75, p. 345-352, 2011.

ESPINOZA, R.F.; MARTINS, R.C. Do discurso sobre a natureza e a natureza do discurso: um estudo de caso sobre a gestão das águas. Nova et Vetera, Roma, v.20, n.64, p. 93-102, 2011.

FALQUETO, M.A. Avaliação do índice de qualidade da água (IQA) e dos elementos químicos nas águas e nos sedimentos do rio Corumbataí - SP. 2008. 116p. Dissertação (Mestrado em Ecologia Aplicada) - Escola Superior de Agricultura "Luiz de Queiroz", Universidade de São Paulo, Piracicaba, 2008.

FERRANTE, V.L.B.; WHITAKER, D.C.A. (Org.). Retratos de Assentamentos. 11. ed. Araraquara-SP: Nupedor/Uniara, 2009. 418p.

FERRAZ, S.F.D.; PAULA, F.R.; VETTORAZZI, C.A. Incorporation sustainability indicators on site selection for Forest restoration in the Corumbatai River basin. Revista Árvore, Viçosa, v. 33, n. 5, p. 937-947, 2009.

GEIST, H.J.; LAMBIM, E.F. Proximate causes and underlying driving forces of tropcial deforestation. BioScience, Washington, v. 52, n. 2, p. 143-150, 2002.

GHELER-COSTA, C.; VETTORAZZI, C.A.; PARDINI, R.; VERDADE, L.M. The distribution and abundance of small mammals in agroecosystems of southeastern Brazil. Mammalia, Paris, v.76, p.185 - 191, 2012.

GOMIERO, L.M.; BRAGA, F.M.S. Ichthyofauna diversity in a protected area in the state of São Paulo, southeastern Brazil. Brazilian Journal of Biology, São Carlos, v.66, n.1a, p.7583, 2006.

INSTITUTO BRASILEIRO DE GEOGRAFIA E ESTATÍSTICA (IBGE). Censo Demográfico Brasileiro 2010. Disponível em: http://www.censo2010.ibge.gov.br. html. Acesso em: 10 ago.2011.

JARDIM, G.M.; ARMAS, E.D.; MONTEIRO, R.T.R. Ecotoxicological assessment of water and sediment of the Corumbataí River, SP, Brazil. Brazilian Journal of Biology, São Carlos, v.68, n.1, p.51-59, 2008. 
JOLY, C.A. ; RODRIGUES, R.R. ; METZGER, J.P. ; HADDAD, C.F.B. ; VERDADE, L.M. ; OLIVEIRA, M.C. ; BOLZANI, V.S. Biodiversity Conservation Research, Training, and Policy in São Paulo. Science, Washington, v. 328, p. 1358-1359, 2010.

LAMARCHE, H. A agricultura familiar: Comparação internacional. Uma realidade multiforme. Campinas: Editora da UNICAMP, 1993. 336p.

LEFF, E. Racionalidade ambiental: a reapropriação social da natureza. Rio de Janeiro: Civilização Brasileira, 2006. 560p.

LIMA-JUNIOR, S.E.; CARDONE, I.B.; GOITEIN, R. Fish assemblage structure and aquatic pollution in a Brazilian stream: some limitations of diversity índices and models for enviornmental impact studies. Ecology of Freshwater Fish, Madri, v. 15, n. 3, p. 284-290, 2006.

MALUF, R. A multifuncionalidade da agricultura na realidade rural brasileira. In: CARNEIRO, M.; MALUF, R. (Org.). Para além da produção: multifuncionalidade e agricultura familiar. Rio de Janeiro: Mauad, 2003. p. 135-152.

MARTINS, R.C. Representações sociais, instituições e conflitos na gestão de águas em territórios rurais. Sociologias, Porto Alegre, n.15, p. 288-325, jan. 2006.

MESSIAS, T.G. Influência da toxidade da água e do sedimento dos rios São Joaquim e Ribeirão Claro na bacia do Corumbataí. 2008. 125p. Dissertação (Mestrado em Ecologia de Agroecossistemas) - Centro de Energia Nuclear na Agricultura, Universidade de São Paulo, Piracicaba, 2008.

MINGOTI, R.; VETORAZZI, C.A. Relative reduction in annual soil loss in macro watershelds due to the relief and forest cover. Engenharia Agrícola, Jaboticabal, v. 31, n. 6, p. 1202-1211, 2011.

MORAIS, E.B.; TAUK-TRONISIELO, S.M.; VENTORINI, S.E. Impacto de atividades agropecuárias na qualidade das águas do rio Cabeça, na bacia do Rio Corumbataí, SP. Holos Environment, Rio Claro, v. 12, n. 1, p. 125-163, 2012.

NOBRE, M.F. O zoneamento ecológico-econômico como instrumento de planejamento e gestão ambiental: uma proposta para a bacia hidrográfica do rio Corumbataí. 2008. 249p. Tese (Doutorado em Geociências) - Instituto de Geociências e Ciências Exatas, Universidade Estadual Paulista,"Júlio de Mesquita Filho" Rio Claro, 2008.

PALMA-SILVA, G.M.; TAUK-TORNISIELO, S.M.; PIÃO, A.C. Capacidade de autodepuração de um trecho do rio Corumbataí, SP, Brasil. Holos Environment, Rio Claro, v.7, n.2, p.139-153, 2007.

PERFECTO, I.; VANDERMEER, J.; WRIGHT, A. Nature's Matrix: Linking Agriculture, Conservation and Food Sovereignty. London: Earthscan, 2009. 272p.

SCHNEIDER, S. (Org.). A diversidade da agricultura familiar. 2. ed. Porto Alegre: Editora da UFRGS, 2006. 295p. 
SILVA, O.H. Agricultura Familiar: comparação internacional. Revista de Sociologia e Política, Curitiba, n.12 p. 161-216, 1999.

TAUK-TORNISIELO, S.M. Unidade de pesque-pague na bacia do rio Corumbataí, diagnóstico socioeconômico ambiental e tratamento de efluentes. Holos Environement, Rio Claro, v. 11, n. 1, p. 31-43, 2011.

TURNER, B.L. II; MEYER, W.B. Global land use and land cover change: an overview. In: Meyer, W.B.; TURNER, B.L.II (Ed.). Changes in land-use and land cover: a global perspective. Cambridge University Press, 1994. p.149-169.

VALENTE, R.O.A; VETTORAZZI, C.A. Definition of priority areas for forest conservation through the Ordered Weighted Averaging method. Forest Ecology and Management, Amsterdam, v. 256, p.1408-1417, 2008.

WANDERLEY, M.N. Prefácio. In: CARNEIRO, M.J.; MALUF, R. (Org.) Para além da produção: multifuncionalidade e agricultura familiar. Rio de Janeiro: Mauad, 2003. p. 9-16.

ZANONI, M.M.; FERREIRA, A.D.D.; MIGUEL, L.A.; FLORIANI, D.; CANALI, N.; RAYNAUT, C. Preservação da natureza e desenvolvimento rural: dilemas e estratégias dos agricultores familiares em Áreas de Proteção Ambiental. Desenvolvimento e Meio Ambiente, Curitiba, n. 2, p. 39-55, 2000. 


\title{
2 CONHECIMENTO CIENTÍFICO E CONSERVAÇÃO AMBIENTAL NA BACIA HIDROGRÁFICA DO CORUMBATAÍ, ESTADO DE SÃO PAULO, BRASIL: ESTADO
} DA ARTE.

\section{Resumo}

A Bacia hidrográfica do Corumbataí tem importância regional em função de ser o principal manancial de abastecimento da região centro-leste do estado de São Paulo. Devido a sua localização, tamanho e importância na produção de bens e serviços ambientais esta Bacia vem sendo estudada por centros de pesquisa regionais, pois são os resultados das pesquisas que possibilitam novas formas de compreensão e melhoria da eficácia da gestão ambiental. No entanto, as dimensões humanas são em geral desconsideradas em pesquisas sobre a questão ambiental na Bacia. Dessa forma, o objetivo deste estudo foi apresentar uma análise da evolução da produção científica dentro da temática socioambiental na Bacia Hidrográfica do Corumbataí, nos últimos 60 anos. A partir de uma revisão sistematizada com a utilização de 42 palavras-chave buscou-se o universo das produções científicas relacionadas à Bacia do Corumbataí. Neste universo amostral foram encontrados 3.026 registros, dos quais, obteve-se 240 registros para dissertações e teses e 130 referentes à artigos científicos. De modo geral, a maior parte das pesquisas encontradas está relacionada à hidrologia, solos e questões ambientais. Os resultados revelam que as produções científicas na Bacia do Corumbataí têm evoluído ao longo dos anos, mas observamos que existe um grande fosso na pesquisa com relação às dimensões humanas. Os resultados permitem refletir sobre a inadequação dos enfoques científicos dominantes no campo da conservação dos recursos naturais que não incorporam as dimensões humanas nos processos de conservação da diversidade biológica e dos recursos hídricos. Este estudo sustenta ainda, que tomadores de decisão não têm acesso às informações advindas das pesquisas, pois estas estão disponíveis somente por meio de bibliotecas de universidades.

Palavras-Chave: Corumbataí; Produção científica; Conservação; Dimensões humanas

\begin{abstract}
The Corumbataí basin has regional importance because of being the main source of supply of central-eastern state of São Paulo. Due to its location, size and importance in the production of environmental goods and services this basin has been studied by regional research centres, as they are research results that provide new ways of understanding and improving the effectiveness of environmental management. However, the human dimensions are generally overlooked in research on environmental issues in the basin. Thus, the aim of this study was to present an analysis of the evolution of scientific production within the environmental theme in Corumbataí Basin during the past 60 years. From a systematic review of the use of 42 keywords searched up the universe of scientific production related to
\end{abstract}


Corumbataí Basin. In this sample universe 3026 records were found, of which yielded 240 records for dissertations and thesis, and 130 scientific articles. In general, most studies found are related to hydrology, soils and environmental issues. The results show that the scientific production in the Corumbataí Basin have evolved over the years, but it was noted that there is a big gap in the research regarding human dimensions. The results allow us to reflect on the inadequacy of the dominant scientific approaches in the field of conservation of natural resources that do not incorporate the human dimensions in the preservation of biodiversity and water resources. This study also claims that decision makers have no access to information from research, as these are only available through university libraries.

Keywords: Corumbataí; Scientific production; Conservation; Human dimensions

\subsection{Introdução}

O rio Corumbataí estabelece comunicação entre os municípios de Analândia, Ipeúna, Itirapina, Charqueada, Santa Gertrudes, Piracicaba, Rio Claro, Iracemápolis, São Pedro e Cordeirópolis, e é exemplo de necessidade de conservação ambiental, dada sua importância no uso de suas águas para abastecimento público, bem como, às funções ecológicas que representa. É neste complexo grupo de municípios, na região centro-leste do Estado de São Paulo, entre os paralelos $22^{\circ} 04^{\prime} 46^{\prime \prime}$ e $22^{\circ} 41^{\prime} 28^{\prime \prime} S$ e meridianos $47^{\circ} 26^{\prime} 23^{\prime \prime}$ e $47^{\circ} 56^{\prime} 15^{\prime \prime} N$, que está situada a Bacia Hidrográfica do Rio Corumbataí.

Esta Bacia Hidrográfica, além de ter importância regional relacionada às atividades econômicas importantes na mineração, turismo e agricultura, tem ainda na dinâmica das suas águas superficiais, um delicado ecossistema que proporciona um capital natural e científico, que permite a formulação de perguntas na pesquisa, gerando assim um manancial de conhecimento acumulado sobre a região. Devido a sua localização, tamanho e importância na produção de bens e serviços ambientais, esta Bacia vem sendo estudada por centros de pesquisa regionais como UFSCAR, USP e UNESP, além de agências como Companhia de Tecnologia de Saneamento do Meio Ambiente - CETESB, Fundação Florestal, CATI e ONGs locais. Isto demonstra que a Bacia é um excelente espaço para o desenvolvimento da pesquisa no Brasil.

A Bacia do Corumbataí é considerada por muitos como uma das mais estudadas, não somente em nível nacional como internacional (TAUK-TORNISIELO, 2008, p.7). As investigações científicas na Bacia tiveram início a partir da década de 1940, sendo o primeiro estudo que se tem registro, o trabalho conduzido por Schubart (1944) "Os diplópodos de Pirassunga", que faz menção ao rio Corumbataí. Nas décadas seguintes outros estudos foram 
conduzidos na Bacia, mas é a partir dos anos 1990, provavelmente pela campanha ambiental da Rio-92, que se intensificam as pesquisas na região. No entanto, é a partir do ano 2000 que ocorre um salto importante nas pesquisas na Bacia do Corumbataí. Isto ocorre em função do aumento da oferta de cursos de pós-graduação nas instituições locais de ensino superior, e consequentemente, maior injeção de recursos financeiros pelas agências de fomento à pesquisa.

Atualmente, os trabalhos relacionados à hidrologia e solos são os mais representativos, seguidos de estudos de cunho ambiental e conservacionista. Todos são unânimes em suas conclusões no que tange à necessidade de mecanismos de conservação da biodiversidade e restauração florestal para manter a Bacia produzindo seus serviços ambientais, principalmente a produção de água. Nota-se, porém, que poucos estudos são dirigidos ou relacionados ao componente social e uma parcela ainda menor envolve a população rural, o que nos permite afirmar que até o momento são inexpressivas na Bacia pesquisas de cunho socioambiental.

Alguns estudos de ecologia, como os trabalhos de Gheler-Costa et al. (2012) e, Dotta e Verdade $(2007,2009,2011)$, apontam para um novo paradigma na conservação ambiental das paisagens agrícolas, especificamente na Bacia do Corumbataí. Estes autores reconhecem a necessidade de "olhar para o todo" e não somente para questões isoladas ou específicas de cada área do conhecimento. Tal fato significa que, não somente os fragmentos florestais, os recursos hídricos, a matriz agrícola ou áreas prioritárias para conservação da biodiversidade devam ser priorizados nas pesquisas cientificas na região, mas sim, os processos de uso e ocupação da terra, bem como suas interações bióticas e abióticas. Este axioma permite então, que lancemos mão de outros questionamentos, dos quais outros conhecimentos serão construídos, o que implica em reconhecer que a ausência dos estudos sócio-ambientais na Bacia não somente restringe, mas compromete a tão preconizada conservação ambiental.

Tendo em vista a importância científica, econômica e ambiental da Bacia do Corumbataí, tem-se observado nas últimas décadas esforços para sua gestão e conservação. No entanto, ainda que os estudos ambientais desenvolvidos na região, ao longo do tempo, contribuam para formulação de políticas públicas conservacionistas, muitos outros ainda são necessários para subsidiarem os gestores e as políticas públicas para sua conservação ambiental.

Atualmente, o número de publicações científicas associado aos recursos computacionais com alta capacidade de armazenamento e velocidade de disseminação via internet, possibilitam revisões robustas para análises e aportes teóricos para fomentar a 
pesquisa científica que, por sua vez, serve de alicerce para a gestão ambiental. Por outro lado, a inexistência de um sistema gestor eficiente e participativo, e o fato dos tomadores de decisão não terem acesso a muitos bancos de dados onde tais pesquisas são depositadas, como revistas indexadas de nível internacional, dificulta a implantação, de facto, de medidas conservacionistas, principalmente por se tratar de uma Bacia considerada produtora de água.

É também verdade que, com a rapidez com que os consensos científicos são refeitos em qualquer que seja o campo de atuação, torna-se indispensável que esses resultados sejam totalmente conhecidos ou administrados por aqueles que desejam tomar decisões. Levando em conta a diversidade de informações de cunho científico geradas na Bacia, este estudo consiste em descrever e caracterizar no contexto histórico, o estado da arte em relação ao conhecimento produzido na região nas últimas décadas. Em termos concretos, o desafio deste estudo foi entender como as produções científicas na Bacia do Corumbataí têm evoluído ao longo dos anos, e apresentar uma análise se estas produções têm ou não considerado a questão do social na questão ambiental para conservação da biodiversidade.

Embora muito já se tenha feito na Bacia, neste trabalho pretende-se fazer uma reflexão sobre a pesquisa e a conservação da biodiversidade, para que a Bacia consiga manter suas funções hídricas e seus serviços ambientais. Diante disso, a seguinte hipótese foi testada: dimensões humanas são em geral desconsideradas em pesquisas sobre a questão ambiental em paisagens agrícolas. Desta forma, o objetivo deste estudo foi apresentar uma análise da evolução da produção científica dentro da temática ambiental na Bacia Hidrográfica do Corumbataí, nos últimos 60 anos, mostrando que a ausência do componente humano nas pesquisas compromete a conservação ambiental.

\subsection{Desenvolvimento}

\subsection{1 Área de Estudo}

O rio Corumbataí tem uma das suas principais nascentes no município de Analândia $\left(22^{\circ} 10^{\prime} 37^{\prime \prime} S\right.$ e $47^{\circ} 44^{\prime} 37^{\prime \prime} N$ ) a partir de um afloramento de água cercado por vegetação ripária pouco conservada, e sua área de preservação permanente está comprometida pelo efeito de borda do uso da terra no entorno que, por sua vez, é uma extensa área com plantio de cana-deaçúcar. A nascente está a 460 metros de altitude e, ao receber água dos tributários Ribeirão Cabeça, Ribeirão Passa-Cinco e Ribeirão Claro, drenam uma área de $171 \mathrm{~km}^{2}$ e têm sua foz a $136 \mathrm{~km}$ da nascente, alimentando o rio Piracicaba (IPEF, 2001). Ao longo do seu curso vem servindo além de fonte de abastecimento, também como corpo de água receptor de resíduos 
industriais e domésticos. Segundo dados da Companhia de Tecnologia de Saneamento Ambiental do Estado de São Paulo - CETESB (2009), a Bacia do Corumbataí 2204'46” e

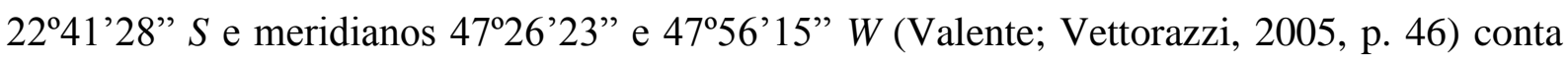
com quase 600.000 habitantes (597.727) e apenas $43 \%$ da carga poluidora recebe algum tratamento.

Os municípios que compõe a Bacia do rio Corumbataí pertencem à UGRHI PCJ (URGHI 5 do Estado de São Paulo). O Instituto de Pesquisas e Estudos Florestais - IPEF (2001) define cinco sub-Bacias dentro da Bacia do Corumbataí (Alto, Médio e Baixo Corumbataí, Passa-Cinco e Rio Claro). O clima na região é caracterizado como subtropical, com sazonalidade bem definida sendo, seco no inverno, com temperatura média na casa dos $17^{\circ} \mathrm{C}$ e chuvosa no verão, com temperatura média de $22^{\circ} \mathrm{C}$ (SALATI, 1996; CEAPLA, 2013). Suas características geomorfológicas são predominantes da era Cenozóica, com as cabeceiras nas cuestas da Serra Geral, típica da bacia sedimentar do Paraná, apresentando quatro formações geológicas tais como, Pirambóia, Rio Claro, Irati e Corumbataí (KOFFLER, 1993,1994). O mesmo autor classifica o relevo da Bacia com presença de morrotes alongados e espigões, e colinas médias e amplas com vales abertos e fechados com presença de lagunas perenes e intermitentes.

Nobre (2008) apresenta para a Bacia Hidrográfica do Corumbataí quatro rios sendo o Corumbataí o principal, e os seus tributários os ribeirões Cabeça, Passa-Cinco e Rio Claro. Segundo Dean (1977), ainda no início do século 19 quase tudo era floresta e cerrado nesta região. Rodrigues (1999) destaca para a região, cinco tipologias de formação florestal: Florestas Estacionais Deciduais e Semideciduais, respectivamente mata-de-planalto e mataseca; Floresta Paludosa e Ripária, respectivamente mata-de-brejo e mata-ciliar; Cerrado com diversas formações de cerrado strictu sensu, cerradão, campo limpo, campo sujo e campo cerrado. Segundo Valente (2005), em 2003 a cobertura do solo é predominantemente marcada por pastagens $(42,29 \%)$, seguido de cana-de-açúcar $(27,77 \%)$, floresta nativa e cerrado $(11,97 \%)$, floresta plantada $(5,69 \%)$, agricultura anual e perene $(4,96 \%)$, área urbana, malha viária, mineração e rede hidrográfica $(7,32 \%)$.

Os municípios que compõe a Bacia do rio Corumbataí pertencem à Unidade de Gerenciamento de Recursos Hídricos dos rios Piracicaba, Capivari e Jundiaí (URGHI 5 do Estado de São Paulo). Segundo o Instituto de Pesquisa e Estudos Florestais - IPEF (2001) pode-se definir cinco sub-bacias dentro da Bacia do Corumbataí (Alto, Médio e Baixo Corumbataí, Passa-Cinco e Rio Claro). A Bacia do Corumbataí é o universo de inferência do estudo proposto (Figura 1). 


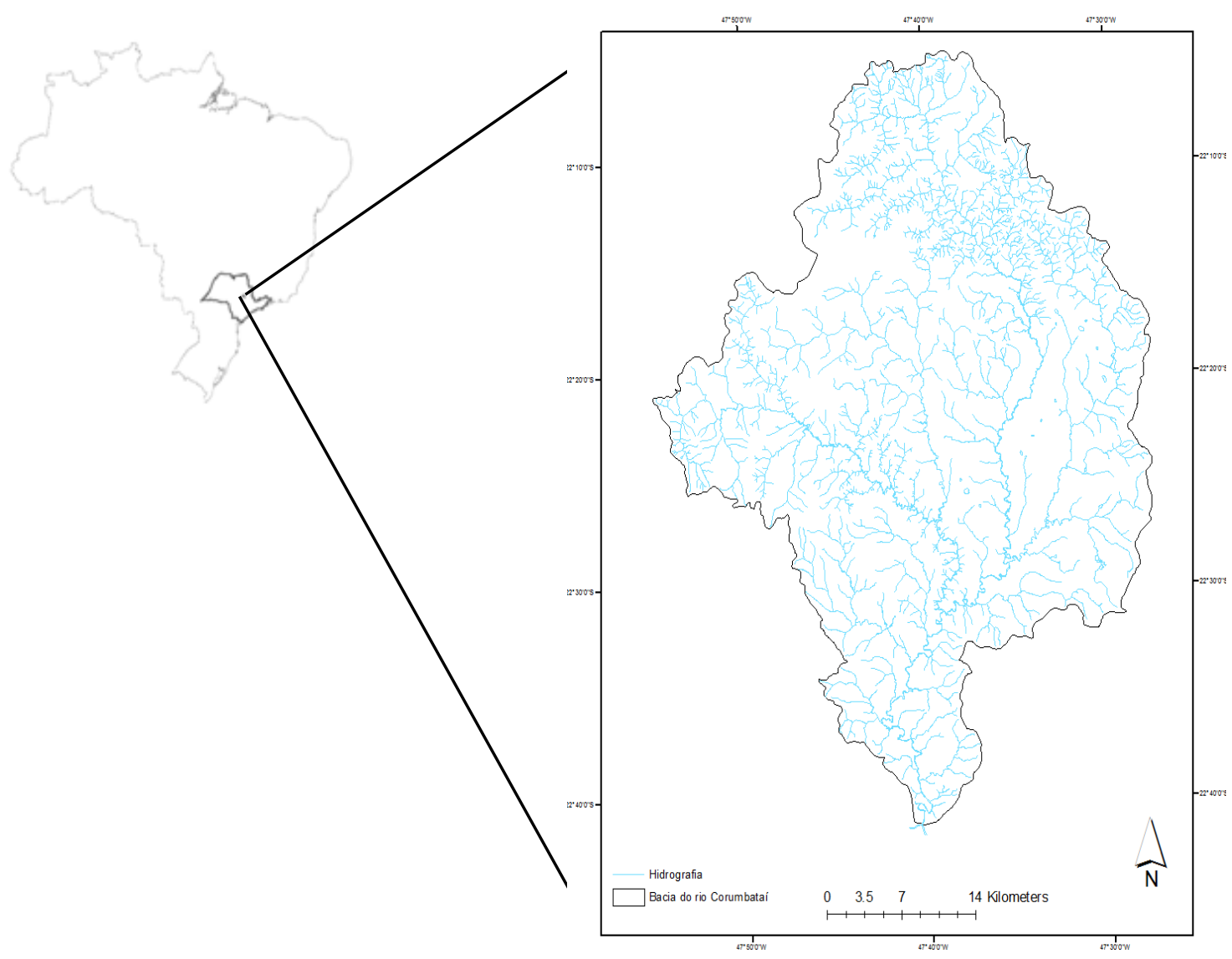

Figura1 - Localização da área de estudo e sua hidrografia

\subsubsection{Metodologia}

\subsubsection{Identificação da necessidade de revisão}

Uma revisão da produção cientifica é necessária, pois são os resultados das pesquisas que apresentam novas formas de compreensão e melhoria da eficácia da gestão ambiental regional. Contudo, nota-se uma tendência de inércia da pesquisa na Bacia do Corumbataí já que, na prática, muitos dos resultados não servem de bases para a política conservacionista. Isso geralmente ocorre por falta de divulgação sistemática em linguagem clara e acessível e dificuldade de acesso às informações por parte dos tomadores de decisão, uma vez que estes não têm acesso aos artigos e outros tipos de publicações referentes à região, nem tão pouco ao robusto banco de dados produzidos por estas publicações. Estes tipos de dados acabam ficando limitados, muitas vezes, somente ao meio cientifico, já que a maioria deles está disponibilizada em revistas científicas que somente podem ser acessadas estando dentro da 
rede (internet) de universidades. Da mesma forma estes dados não são disponibilizados em linguagem adequada para o público em geral, pois cientistas comunicam-se entre si via artigo científico. Deve-se considerar também, que há certa dificuldade por parte dos pesquisadores em decodificar e/ou escrever sobre e para a população local, pois muitas vezes o conhecimento local é hierarquizado e classificado como conhecimento leigo e senso comum (SANTOS, 2006). Além do que os especialistas se acomodam e não enfrentam as dificuldades de compreensão das formas de construção histórica destes conhecimentos, e como conseqüência disto, reproduzem um discurso onde os leigos devem ser capacitados para a gestão ambiental. Uma das principais consequências desta falta de acesso e/ou disponibilidade mais flexível das informações é a ausência ou pequena participação da comunidade e da internalização de conceitos como conservação e recuperação ambiental na comunidade local, refletindo no atual quadro de degradação ambiental da Bacia.

Podemos dizer que a supressão de áreas naturais em decorrência de quase três séculos de desenvolvimento proporcionou à Bacia do Corumbataí um processo de fragmentação da vegetação natural, que tem sido tratado como um sério problema na conservação dos recursos hídricos. Portanto, foram as transformações de um ecossistema natural em um agroecossistema que resultaram na redução da biodiversidade local, causando consequências diretas e inevitáveis ao seu conjunto, fazendo da Bacia alvo de investigações científicas. Da mesma forma que os processos de uso e ocupação da terra na Bacia afetam os serviços ambientais a que ela serve, estes afetaram também a agricultura familiar, por consequência, colocando-a como um problema a ser investigado. O presente estudo não pretende responder diretamente a tais questionamentos, mas apontar sugestões que justifiquem esse tipo de pesquisa. 


\subsubsection{Proposta para revisão e identificação dos termos}

Existem excelentes bases para consulta de dados científicos gerados para a área em questão, como o Projeto PIRACENA disponível em www.cena.usp.br/piracena e o Atlas Ambiental da Bacia do Rio Corumbataí disponível em www.ceapla2.rs.unesp.br/atlas. Contudo, a revisão aqui proposta vai além destes dois bancos de dados, indo à busca de todo o arcabouço científico possível gerado até o presente momento para a Bacia Hidrográfica do Rio Corumbataí, para testar a hipótese de que a dimensão humana é desconsiderada na maioria dos estudos em paisagens agrícolas, e que existe um antagonismo entre o que se preconiza nas pesquisas e a realidade ambiental atual da Bacia. Pretendemos também, por meio desta revisão de literatura, mostrar que na prática as políticas públicas referentes à gestão e conservação desta Bacia desconhecem o conhecimento científico produzido nas últimas décadas. Para atender nossos objetivos foram realizados dois tipos de consultas que compreendem o universo pesquisado: acervos de bibliotecas do pólo científico regional e inventário das produções/publicações de cunho científico em meios indexados como periódicos nacionais e internacionais.

No meio científico/acadêmico quando se fala em Bacia hidrográfica extrapola-se para uma diversidade de termos que compreendem este universo. Por si, o termo "bacia hidrográfica", na sua concepção e propósito, contempla um vasto repertório de palavras que o definem como unidade de gestão. Assim, na busca das referências, especificamente para a região de estudo, foram utilizados os seguintes termos em português e seu correspondente em inglês: vegetação nativa (native forest), eucalipto (eucalyptus), cana-de-açúcar (sugarcane), pastagem (grassland), agrotóxico (pesticides), poluição (pollution), fragmentação (fragmentation), biodiversidade (biodiversity), fauna (fauna), flora (flora), vertebrados (vertebrates), invertebrados (invertebrates), peixes (fish), mamíferos (mammals), aves (birds), répteis (reptile), anfíbios (amphibian), insetos (insects), paleontologia (paleontology), unidade de conservação (conservation unit), área de proteção ambiental (environmental protection area), gestão ambiental (environmental manegement), meio ambiente (environment), ambiental (environmental), educação ambiental (environmental education), sustentabilidade (sustainability), conservação (conservation), água (water), solo (soil), agricultura familiar (family agriculture), sociologia (sociology), antropologia (anthropology), meio rural (rural), ruralidades (rurality), sociologia rural (rural sociology), agricultura (agriculture), produção agrícola (agricultural production), economia (economy), Passa-Cinco, Cabeça, Ipeúna e Analândia, todas truncadas com Corumbataí. Tendo em vista o objetivo e a preocupação com 
a produção científica para a região, no que tange à oferta de conhecimento produzido, priorizamos nossa busca em relação à palavra-chave "Corumbataí". Acreditamos que quaisquer estudos realizados nos limites da Bacia Hidrográfica do Corumbataí, seja qual for seu caráter específico, seja ele nas ciências naturais ou sociais terão ao menos uma citação dos termos apresentados. Para evitar sobreposição com a "formação Corumbataí", que vai além dos limites da Bacia, foi utilizado nas buscas o filtro "Corumbataí not formação". Por sua vez, não foi aplicado nenhum filtro nas buscas via web, ou seja, a palavra-chave não foi restringida a campos específicos ou campos isolados, de tal modo, que poderia aparecer no título, resumo, palavra-chave ou no corpo do texto.

As bases de dados utilizadas para a revisão foram as seguintes: Biblioteca digital da Empresa Brasileira de Pesquisa Agropecuária - Embrapa (www.bdpa.cnptia.embrapa.br), Biblioteca digital da Universidade Estadual Paulista "Júlio de Mesquita" - UNESP (www.unesp.br/biblioteca), Biblioteca digital da Universidade de Campinas - UNICAMP (www.sbu.unicamp.br), Biblioteca digital da Universidade de São Paulo - USP (www.esalq.usp.br/dedalus), Biblioteca digital da Universidade Federal de São Carlos ( $\underline{\text { www.ufscar.br) }}$, Biblioteca Digital Brasileira de Teses e Dissertações (www.bdtd.ibict.br), e as bases de dados da Coordenação de Aperfeiçoamento de Pessoal de Nível Superior -

CAPES (www.periodicos.capes.br), Scopus (www.scopus.com), Web of Science (www.portal.isiknowleedge.com) e Scientific Eletronic Library Online - Scielo (www.scielo.org).

\subsubsection{Extração e compilação dos dados}

Os dados obtidos a partir da revisão descrita acima foram sistematizados em tabelas de acordo com sua origem, sendo divididos da seguinte forma: Teses (teses e dissertações), artigos científicos revisados por pares e outros (mapas, livros, monografias, resumos de congressos). Os resultados foram desta forma conduzidos para que pudéssemos também verificar qual o número de estudos realizados na Bacia que de fato foram tornados públicos, ou seja, foram enviados a revistas, analisados por pares e então publicados. Por sua vez entendemos que teses, dissertações, monografias e resumos de congressos são textos acadêmicos e não científicos.

Foi estabelecido um índice de frequência de registros a fim de padronizar o esforço amostral entre os diferentes bancos de dados analisados, uma vez que alguns registros podem 
ocorrer ou não em mais de um deles. Para isso utilizamos a seguinte fórmula, onde $i$ se refere ao número de registros encontrados em cada banco de dados analisado:

$$
\text { Índice de frequência de registros }=\frac{\text { Número de registros do banco de dados } i}{\text { Número total de registros levantados }}
$$

\subsubsection{Resultados e Discussão}

Os resultados das buscas realizadas, via internet, nas bibliotecas digitais e bases de dados de periódicos revisados por pares, de acordo com as 42 palavras-chave utilizadas, estão sistematizados no anexo A e são referentes às produções científicas realizadas na região de estudo entre os anos de 1950 e junho de 2012. No universo amostral referentes ao termo Corumbataí e seus complementares foram encontrados 3.026 registros. Como expressão da evolução da produção científica observamos que há um aumento a partir do ano 2000, com tendência de evolução para a próxima década (Figura 2).

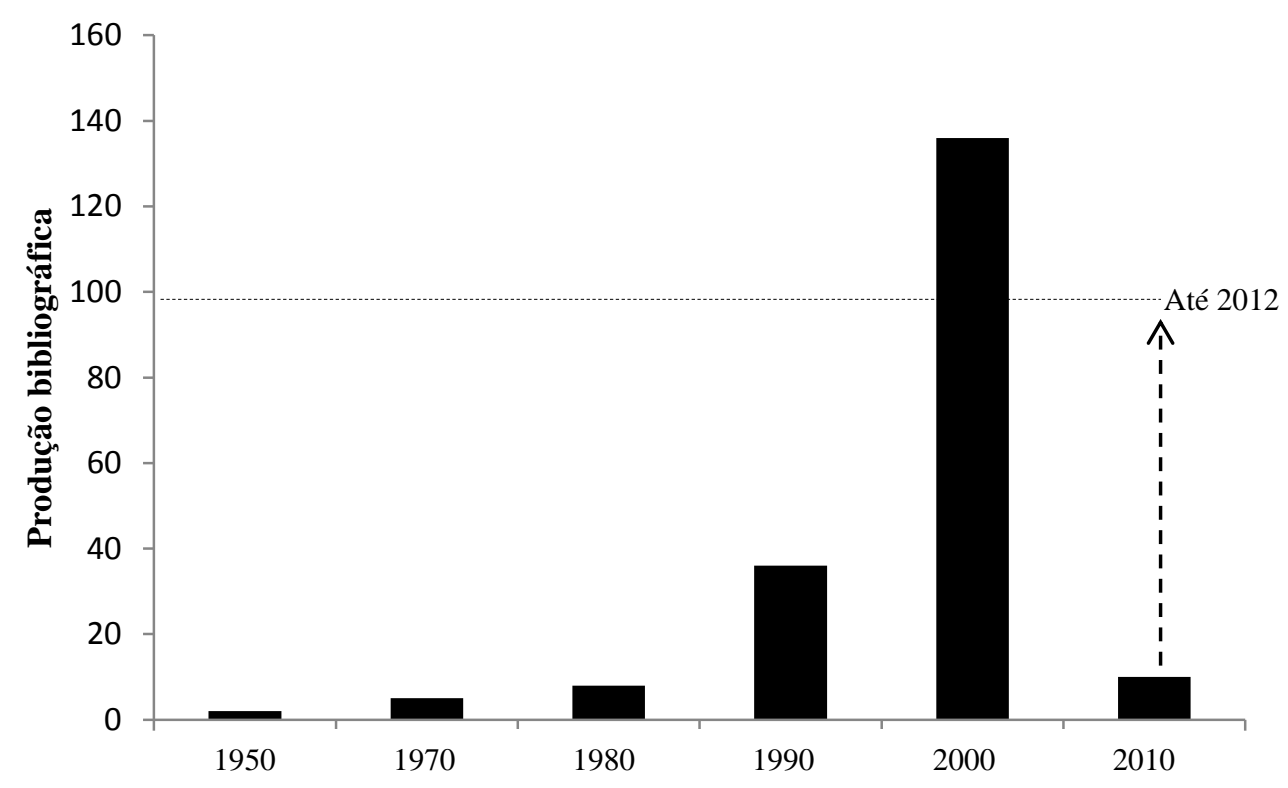

Figura 2 - Evolução da produção bibliográfica por década na Bacia do Corumbataí

Em relação às 42 palavras-chaves utilizadas, verificamos que as produções no conjunto de temas apresentados há maior "oferta" da produção relacionada à temática ambiental e menor relacionada à temática social (Figura 3). 


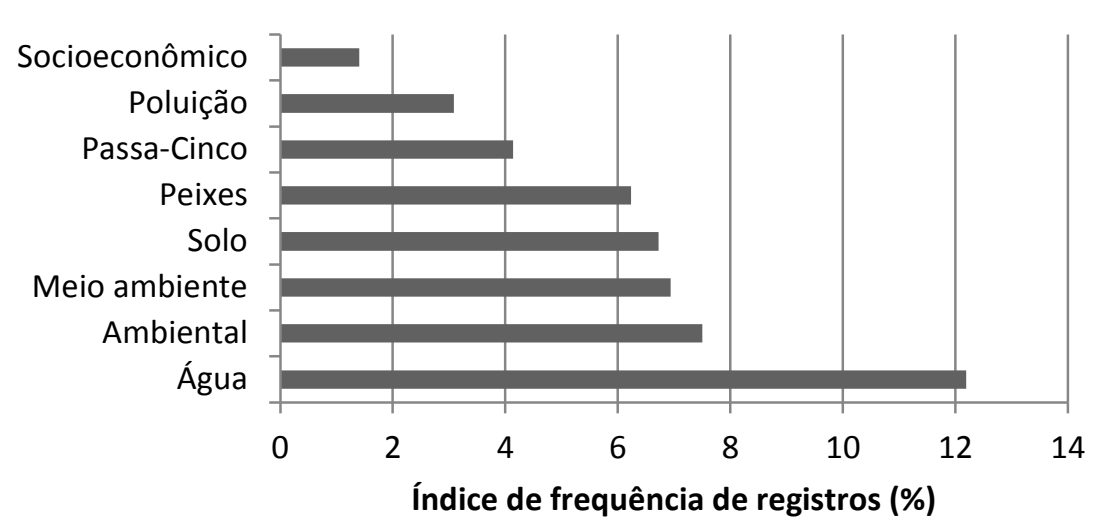

Figura 3 - Índice de frequência de registros em relação às palavras-chave de maior ocorrência

Observa-se que nas bibliotecas pesquisadas o número de dissertações e teses $(\mathrm{N}=240)$ disponívies é maior que o número de artigos, sendo estes apenas disponibilizados na biblioteca digital da USP $(\mathrm{N}=31)$. A maioria dos artigos científicos referentes à área de estudo somente está disponível em bancos de dados específicos como os utilizados neste estudo $(\mathrm{N}=130)$. Dentro da categoria "outros" encontram-se mapas, livros, resumos de congresso, monografias e notas técnicas (Figura 4).

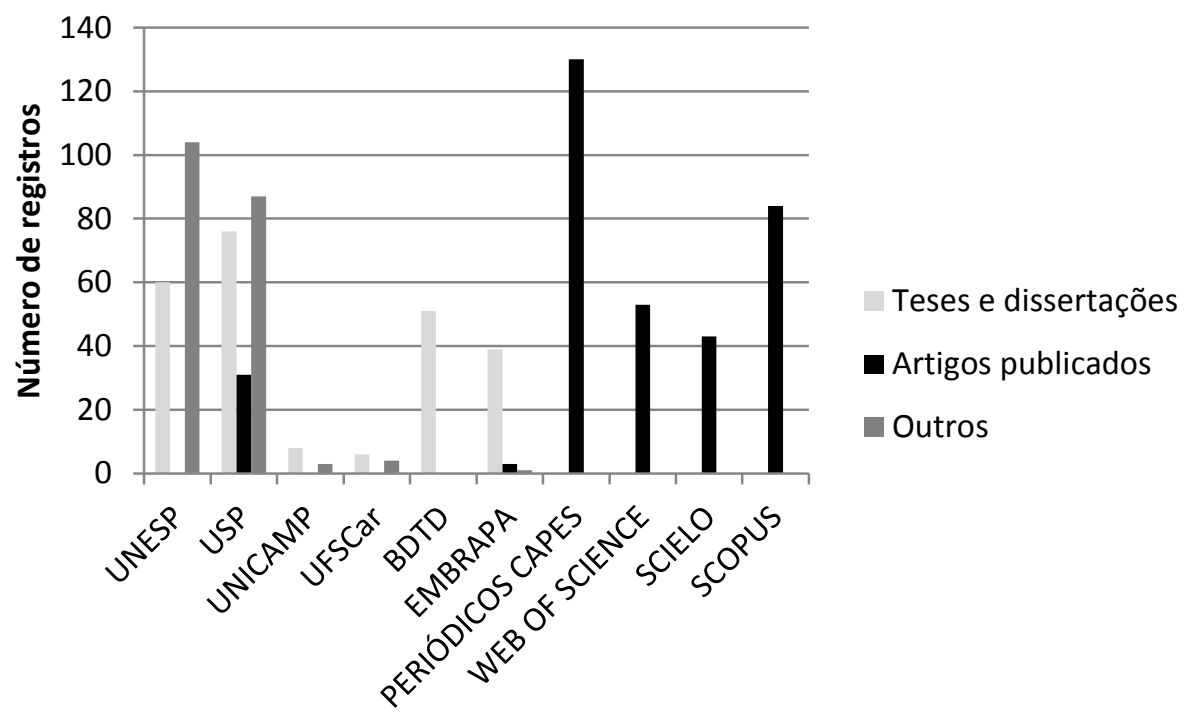

Figura 4 - Número de registros encontrados nos bancos de dados analisados

Nos bancos de dados analisados observa-se uma grande quantidade de trabalhos acadêmicos relacionados às questões hidrológicas, pedológicas e ao meio ambiente (Figuras 5 e 6), sendo que dentro dos bancos de dados de bibliotecas digitais, a biblioteca da USP 
apresenta um maior número de estudos relacionados à região do Corumbataí $(\mathrm{N}=194)$ (Figura $6 a)$.

a)

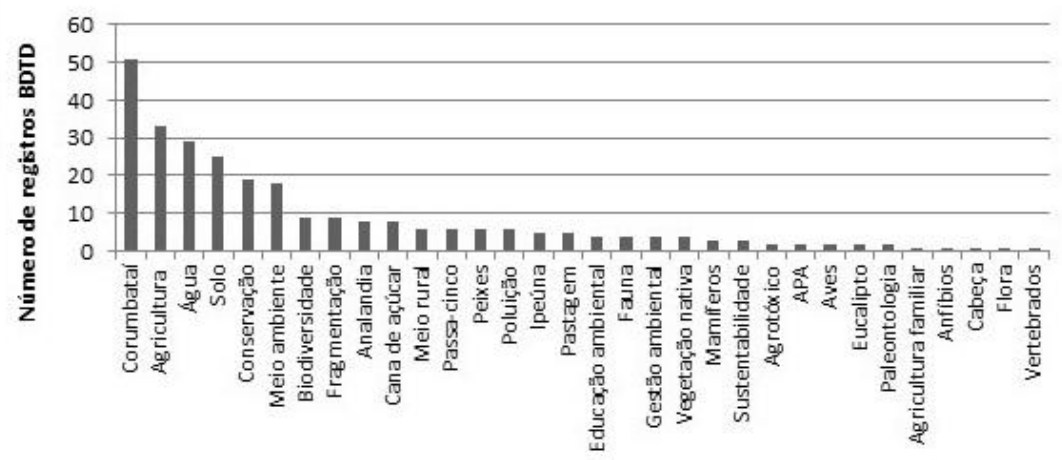

b)

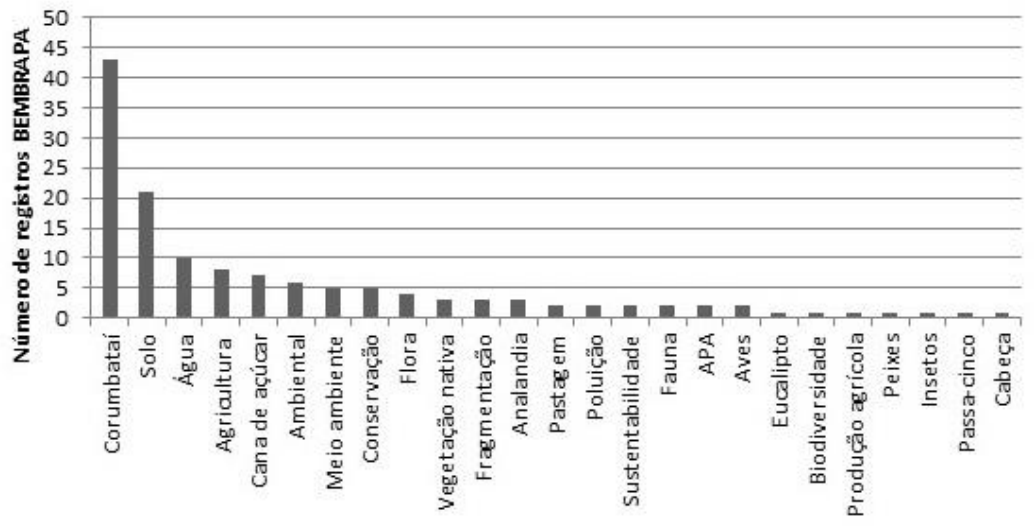

Figura 5 - Número de registros encontrados no cenário nacional: a) Biblioteca Digital Brasileira de Teses e Dissertação; b) Biblioteca da Empresa Brasileira de Pesquisa Agropecuária 
a)

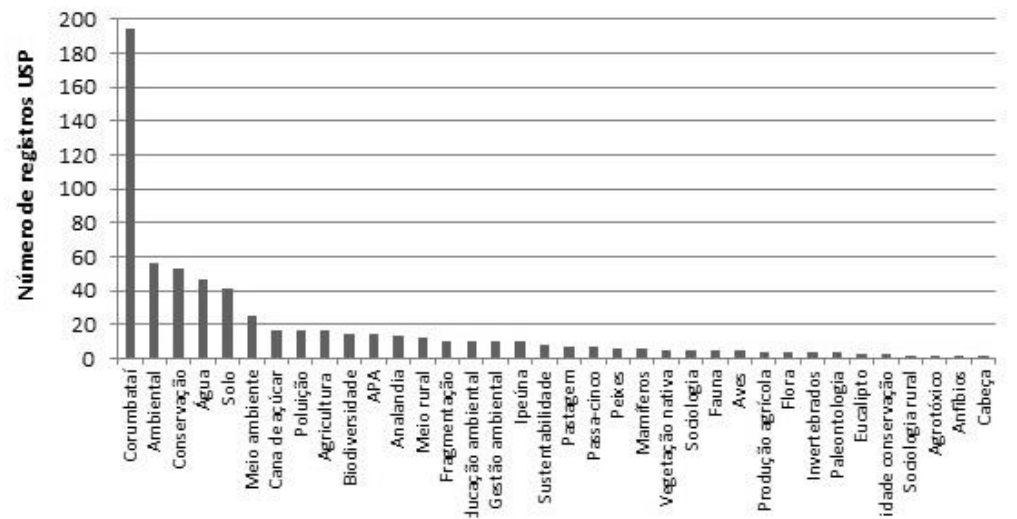

c)

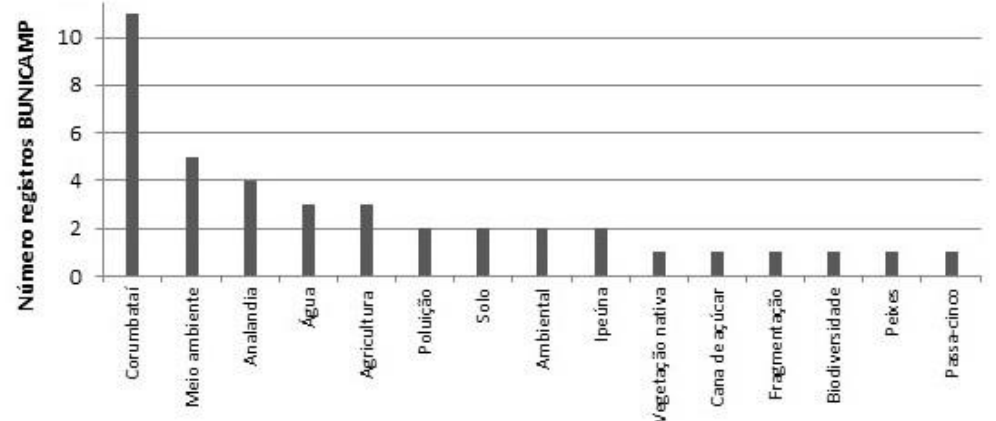

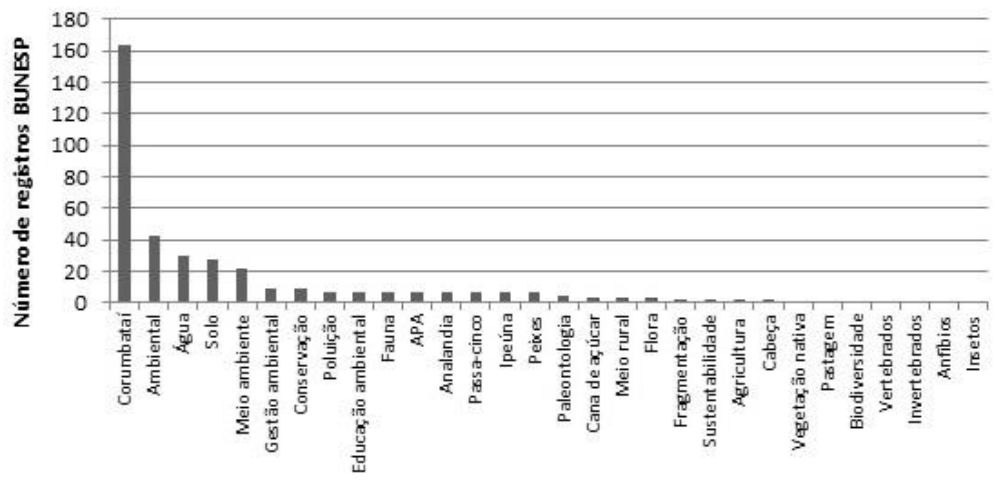

d)

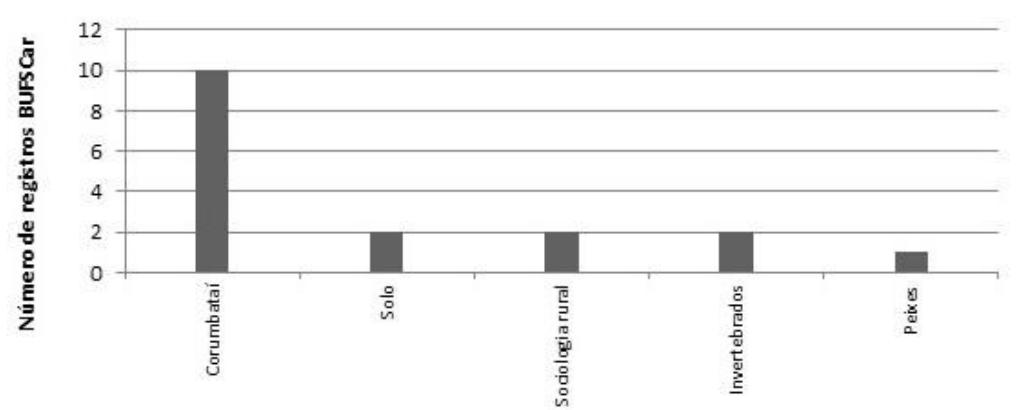

Figura 6 - Número de registros encontrados no cenário estadual: a) Biblioteca Digital da USP; b) Biblioteca Digital da UNESP; c) Biblioteca Digital da UNICAMP; d) Biblioteca Digital da UFSCar 
Com relação aos bancos de dados referentes a periódicos indexados, como não poderia deixar de ser, foi encontrado o mesmo padrão onde é possível verificar que, incorporado ao termo Corumbataí, o assunto água é o mais frequente, seguido dos assuntos meio ambiente, ambiental, solos e peixes (Figura 7).

Tendo em vista a preocupação em demonstrar que as dimensões humanas são desconsideradas nas pesquisas na Bacia do Corumbataí, em relação às demais áreas do conhecimento, o conjunto de palavras-chave utilizado foi satisfatório, já que as palavraschave: antropologia, sociologia, ruralidades e meio rural, pouco apareceram nas buscas. Destacam-se, portanto, as palavras-chave Corumbataí, no que tange à "oferta" das produções científicas, seguidas de meio ambiente, água, solo e peixe, sendo estas do grupo das palavraschave das áreas das ciências naturais. De modo geral, a maior parte dos estudos aqui levantados está relacionada à hidrologia, solos e questões ambientais (Figura 8), evidenciando a validação da hipótese deste estudo: as dimensões humanas não são, em geral, consideradas em pesquisas realizadas na Bacia. 
a)

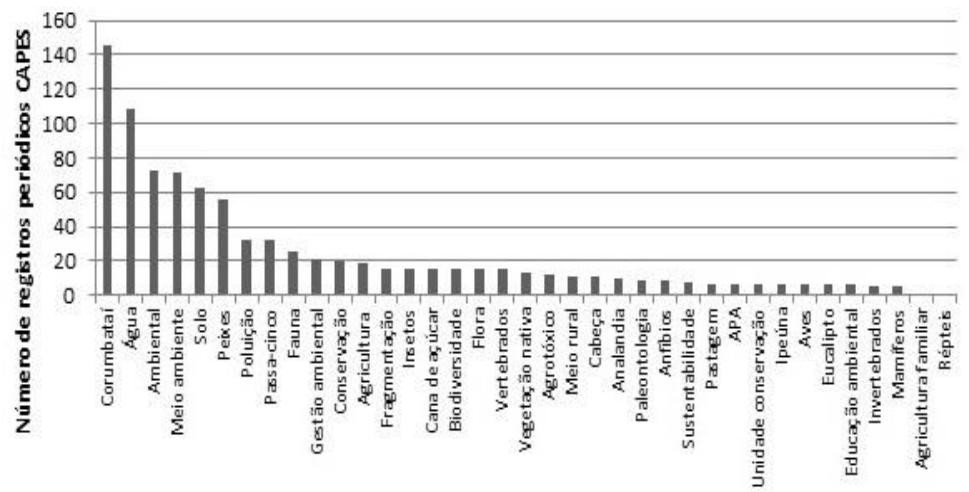

c)

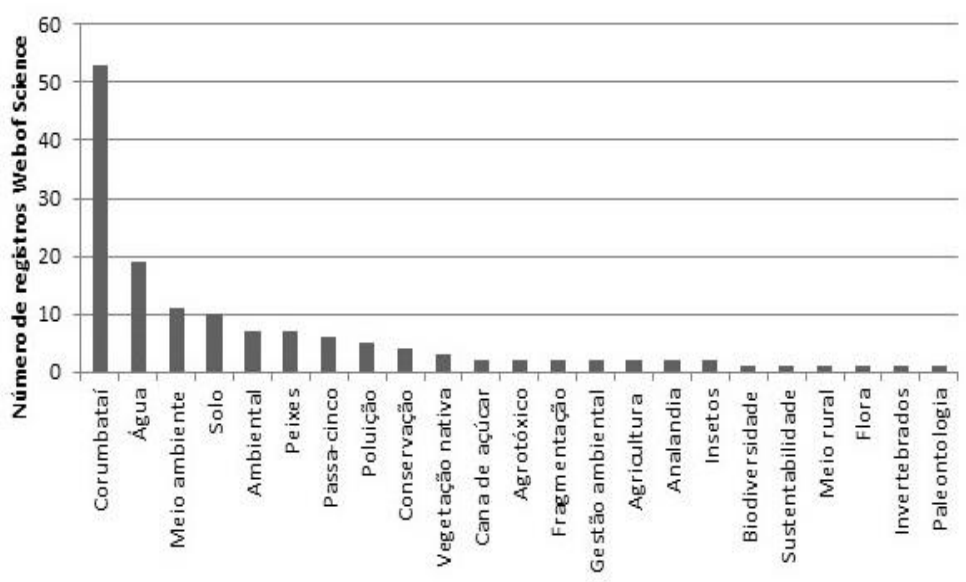

b)

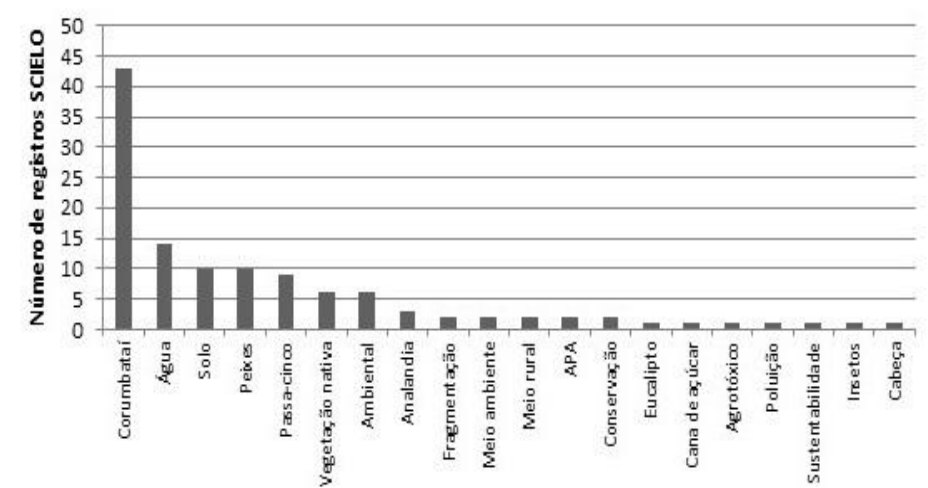

d)

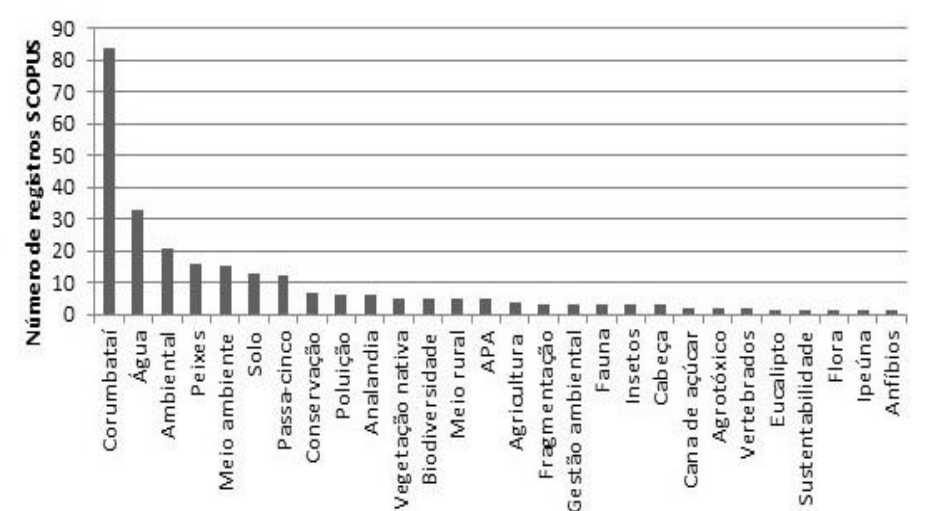

Figura 7 - Número de registros encontrados em bancos de dados referentes a publicações científicas: a) Periódicos CAPES; b) SCIELO; c) Web of Science; d) SCOPUS 


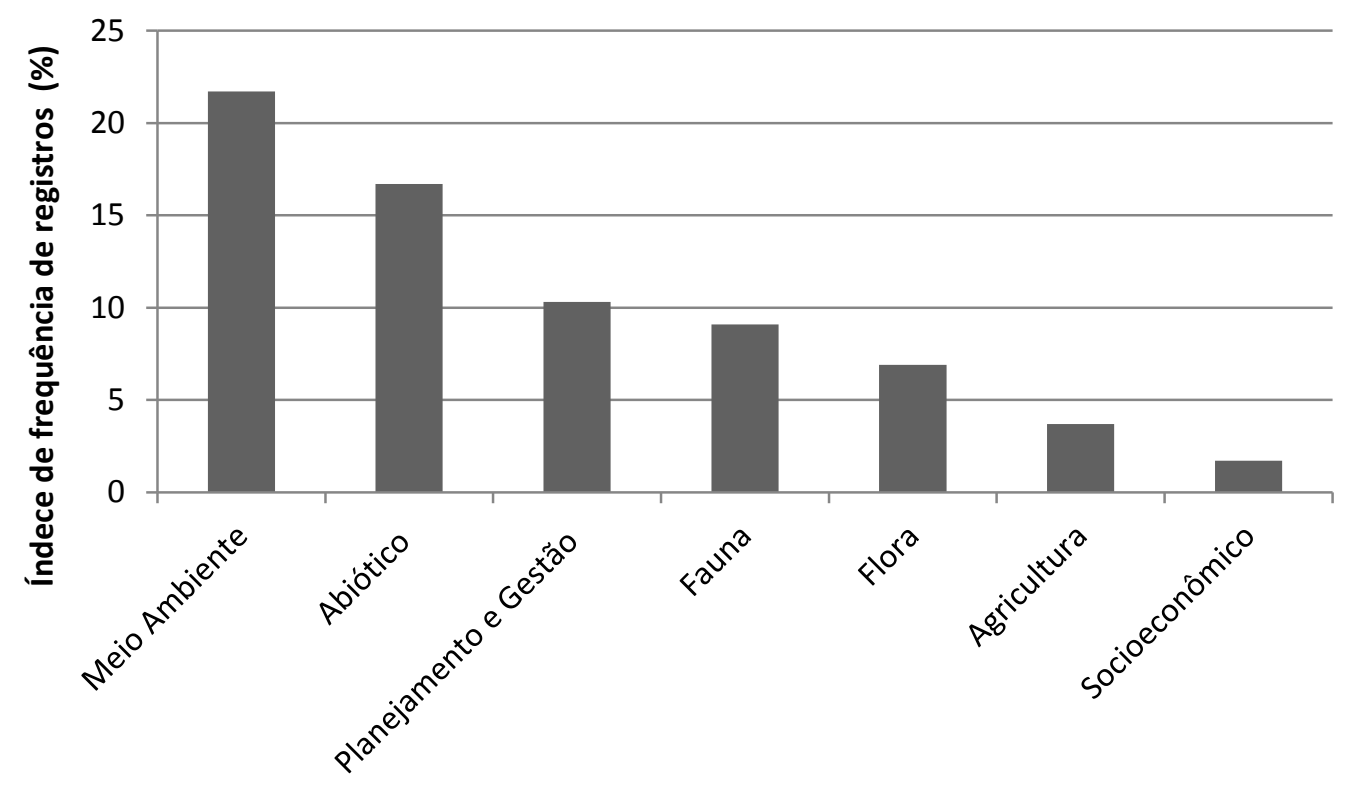

Figura 8 - Índice de frequência de registros em relação às grandes áreas de pesquisas realizadas na Bacia do Corumbataí

$\mathrm{Na}$ análise das produções científicas sobre a Bacia do Corumbataí, as mais representativas são aquelas selecionadas a partir das palavras-chave Corumbataí/água/solos/meio ambiente/agricultura. Por não se tratar de um trabalho de revisão, priorizamos a leitura de alguns artigos por temas específicos.

Nos trabalhos de Armas et al. (2005), Armas et al. (2007), Borges et al. (2008), Cetra e Petrere (2006), Falqueto (2008), Jardim et al. (2008), Lima-Junior et al. (2006), Messias (2008), Morais et al. (2012), Palma-Silva et al. (2007) e Tauk-Tornisielo (2011) observamos que estes são unânimes em apresentar as condições desfavoráveis da água da Bacia do Corumbataí. Mesmo tratando de pesquisas com foco e métodos distintos, há um padrão nos artigos, e ambos corroboram a ideia de que os corpos d'água da Bacia apresentam significativas alterações e ainda, que a qualidade da água da Bacia tem caído ao longo do tempo, devido principalmente pela poluição, tema de muitos artigos. A revisão dos artigos publicados entre 2005 e 2012 enfatiza, por exemplo, a contaminação dos corpos d'água e dos sedimentos existentes nos rios da Bacia por herbicidas provenientes do mau uso da terra e de locais onde o manejo do solo não é realizado de forma adequada (ARMAS et al., 2005; ARMAS et al., 2007; BORGES et al., 2008; CETRA; PETRERE, 2006; FALQUETO, 2008; JARDIM et al., 2008; LIMA-JUNIOR et al., 2006; MESSIAS, 2008; MORAIS et al., 2012; 
PALMA-SILVA et al., 2007; TAUK-TORNISIELO, 2011). Os trabalhos com agrotóxicos na Bacia apontam que os níveis de herbicidas utilizados na cultura da cana-de-açúcar, encontrados na água são 13 vezes maiores que o limite europeu, refletindo um alto risco à biota. Estes estudos apontam ainda, que as análises de qualidade da água na Bacia não contemplam o diagnóstico da presença de pesticidas e, no entanto, sabe-se que estes devem estar presentes, uma vez que são intensamente utilizados na área. Fica assim, urgente, a necessidade da avaliação da presença de resíduos de herbicidas e pesticidas na água durante o monitoramento ambiental o que, segundo alguns autores, não tem sido realizado na Bacia. Um fator ainda mais agravante desta situação é que no Brasil não há parâmetros para estabelecer limites sobre a presença de resíduos de tais agroquímicos na água (ARMAS et al., 2007).

Alguns estudos selecionados para análise tratam da fauna de peixes ou ictiofauna, e destacam, por exemplo, que o lançamento de esgoto doméstico sem tratamento tem alterado a comunidade de peixes na Bacia (CETRA; PETRERE, 2006; LIMA-JUNIOR et al., 2006). Tais estudos enfatizam ainda que pesque-pagues têm comprometido a qualidade de água total da Bacia. Por apresentarem valores de amônia-nitrogênio, fósforo, ph, turbidez e coliformes totais acima do permitido pelo CONAMA, havendo a necessidade de tratamento de seus efluentes (TAUK-TORNISIELO, 2011). Portanto, é fator comum nos artigos que a qualidade dos recursos hídricos na Bacia do Corumbataí, seja para o consumo ou para vida aquática, vem piorando ao longo dos anos, sendo urgente um sistema de tratamento de esgoto doméstico, fiscalização no lançamento de efluentes industriais, restauração das matas ciliares, e controle de erosão e assoreamento, pois existe um grande carreamento de solo e outros materiais para dentro do rio, aumentando a quantidade de poluentes nas águas e, comprometendo de modo geral a sócio-biodiversidade.

Com referência ao uso da terra os trabalhos de Silva e Cunha (2008), Tavares et al. (2007) e Zambeta (2006), retratam a Bacia do Corumbataí como bastante comprometida, com terras degradadas, de baixa aptidão agrícola, erodidas e mal utilizadas. Postulam ainda, que o uso desordenado da terra na Bacia, devido à devastação da vegetação natural, está comprometendo os elementos da paisagem responsáveis pela manutenção dos recursos hídricos e, por sua vez, estes se encontram em condições favoráveis à ocorrência de enchentes. Os autores mencionam também que os remanescentes florestais da Bacia estão sob séria ameaça por incêndios advindos das pastagens e/ou da cana-de-açúcar.

Outro aspecto aqui analisado é referente à biodiversidade em sentido amplo, onde os trabalhos trazem colaborações importantes para formulação ou sustentação de políticas 
conservacionistas. A revisão dos trabalhos de Dotta e Verdade, (2007, 2009, 2011), Ferraz et al. (2009), Gheler-Costa et al., (2012), Gomiero e Braga, (2006), Mingoti e Vettorazzi, (2011), Morais et al., (2012) e Valente e Vettorazzi, (2008), em relação à vegetação nativa e à fauna destacam, de forma geral, a importância dos fragmentos florestais e das matas ciliares da Bacia, principalmente, porque a perda da cobertura florestal tem levado a um aumento no assoreamento dos rios, perda de solo e comprometimento da fauna. Por sua vez, o quesito fauna está diretamente relacionado à questão flora, onde as paisagens heterogêneas estão dominadas por uma fauna generalista adaptada a usar diferentes tipos de habitats e itens alimentares. Portanto, a grande variabilidade de habitats e diferentes condições ambientais na Bacia podem de modo geral, refletir negativamente na conservação da fauna e da flora. Desse modo, alguns dos autores sinalizam que, como os fragmentos maiores que 60ha no PassaCinco são os mais bem conservados e preservados em toda a Bacia, garantir a restauração das sub-Bacias do Passa-Cinco e Alto Corumbataí é estratégia crucial para a manutenção da biodiversidade. Conclui-se, portanto, que a restauração florestal dos melhores fragmentos e a recomposição das matas ciliares favoreceria a conexão entre os fragmentos, facilitando a ligação e dispersão das espécies de fauna e flora de modo geral, fatores estes diretamente relacionados à participação do componente social da Bacia.

Referente às questões sociais e ruralidades destacamos os estudos de Antoniazzi (2008), Comin, Gheler-Costa e Garavello (2011), Comin et al., (2009), Fuini (2008) e Nobre (2008), que afirmam que as transformações nos usos da terra na Bacia nas últimas décadas vêm afetando a identidade local, a noção de territorialidade e as relações a respeito dos elementos naturais da paisagem agrícola pela população rural. Economicamente, houve um aumento no êxodo rural na Bacia, que pode ser justificado pela falta de incentivos para manutenção do homem no campo. Esses incentivos poderiam ser através de subsídios das práticas adequadas, estímulo à demanda de produtos ambientalmente amigáveis e pagamentos diretos pelos serviços ambientais produzidos, uma vez que, a adoção de práticas com maior produção de serviços ambientais depende de incentivos, e deve ser encorajada na Bacia, garantindo de forma efetiva, a participação das dimensões humanas na conservação.

$\mathrm{Na}$ totalidade da produção científica gerada na região é senso comum entre os autores supracitados que as condições da Bacia do Corumbataí vêm piorando ao longo do tempo, mesmo diante de tantas pesquisas científicas realizadas na área. Esta situação é preocupante por inúmeros motivos, entre eles: a Bacia é produtora de água que serve de abastecimento para quase 1 milhão de pessoas; está inserida em uma Unidade de Conservação (UC) na categoria de Área de Proteção Ambiental (APA), mas não há mecanismos de gestão eficazes; 
a conservação da fauna e flora local está comprometida diante das atuais atividades agropecuárias na área; a qualidade do solo e das águas vem piorando ao longo do tempo; há a necessidade urgente de um plano de restauração das matas ciliares; controle da poluição e a criação de estações de tratamento de esgotos.

Os resultados apresentados neste estudo possibilitam refletir sobre a inadequação dos enfoques técnico-científicos dominantes no campo da conservação dos recursos naturais na área em questão, que não incorporam as dimensões humanas nos processos de conservação da diversidade biológica e dos recursos hídricos. Deixando evidente a necessidade de pesquisas com o componente social, principalmente do meio rural da Bacia do Corumbataí, onde segundo dados estimados a partir do IBGE (2010) residem entre 6 e 8 mil habitantes. Segundo Martins (2007), numa abordagem sociológica da questão hídrica, territorial e ambiental em áreas rurais, diz ser pertinente o entendimento e a interpretação da história da área, das formas de reprodução da localidade e do universo cotidiano, que por vezes reitera e desafia as conjunturas de hegemonia simbólica e material do lugar. Nesse sentido, Lisboa (2008) sugere que os fatores sociais, ambientais, políticos e principalmente históricos não devem ser deixadas em segundo plano.

De forma geral, o presente estudo vai ao encontro do que foi proposto por Kuhn (1970), quando atenta para o enrijecimento das ciências aplicadas, "onde a imposição de alguns conceitos impera com independência diante do contexto social". Nota-se ainda hoje que para o entendimento das relações que se estabelecem entre sociedade e natureza, economia e meio ambiente, durante a elaboração de políticas ambientais lança-se mão de instrumentos que seguem a economia ambiental (MARTINS, 2008). Esta visão se aproxima do proposto por Kuhn, principalmente por não ser linear no entendimento das relações, seguindo valores ocidentais, não levando em consideração as diferentes situações sociais (MARTINS, 2008). No caso do conhecimento científico e a conservação ambiental na Bacia do Corumbataí, a falta de pesquisa com dimensões humanas, bem como, pesquisas que integrem o componente social da paisagem rural pode ser consequência de três possíveis fatores: a) pesquisadores das ciências sociais aparentemente não manifestam interesse em desenvolver pesquisas sobre a temática socioambiental em agroecossistemas; b) as ciências naturais não incorporam o componente social em suas pesquisas, muitas vezes ignorando que são os sistemas sociais que manejam os recursos ambientais na paisagem; e c) ausência de diálogo entre essas áreas, já que o problema é único e a participação das dimensões humanas nas pesquisas pode oferecer vantagens para ambas, especialmente na forma de enxergar as interações homem-ambiente. 
Para Brondizio e Moran (2008), entender os processos que mediam a percepção das alterações ambientais e a resposta comportamental individual e da comunidade local é elemento chave em pesquisas dos sistemas naturais humanos acoplados. Existem bons exemplos no debate científico que conciliam as ciências sociais e naturais, aproximando estes dois campos (VITOUSEK et al., 1997; THOMAS, 1956; TURNER II et al., 1990; BERKES et al., 2003; LIU et al., 2007; BEGOSSI, 1993; BERLIN, 1992; DREW, 2006; MORAN, 1990). Há também em outras partes do mundo experiências unindo às características dos recursos naturais, interações dos atores sociais, de governança e participação política, troca de informações, e as questões econômicas que suportam espaços para ambos os conflitos e sinergias entre conservação e desenvolvimento rural (ROMERO et al., 1997; MORAN; BRONDIZIO; MACCRACKEN, 2002). Bacon et al. (2002). Estes estudos demostram como é possível unir esforços para melhorar a qualidade de vida rural, garantir os direitos dos trabalhadores, permitir democracia rural, conservar a biodiversidade e manter cultural tradições. No Brasil, existem trabalhos com enfoque em gestão participativa e integrada considerando os seres humanos como parte do ecossistema (BERKES, 2005; SEIXAS, 2005; RIBEIRO; GALIZONI, 2002; VIEIRA et al., 2005; MORAN, 2011). No entanto, especificamente na Bacia ainda prevalece uma hegemonia da pesquisa de sentido positivista sem uma visão sistêmica dos problemas sócio-ambientais.

Santos (2006) se posiciona sobre o caráter pré-paradgmático de Khun e afirma que deve haver uma superação da dicotomia ciências naturais e sociais. Para Santos (2006), todo conhecimento científico-natural é científico-social, sendo que o paradigma emergente tende a ser um conhecimento que se funda e supere a distinção entre essas ciências. Segundo Moran (2011), ainda que essas questões possam dividir os cientistas sociais e naturais em relação às suas ênfases sobre o ambiente ou as pessoas, é importante entender que há muitas razões que podem mudar os direcionamentos da pesquisa sobre conservação da biodiversidade, entre elas, estéticas, culturais, econômicas e não apenas biológicas.

Moran et al. (1996) relembram que foram as ciências físicas que evidenciaram o papel das ações humanas e que encorajaram a comunidade de cientistas sociais (economistas, entre eles) para integrar-se no esforço de entender as mudanças ambientais globais. Assim, as pesquisas com as dimensões humanas desafiam a maioria das ciências sociais para desenvolver novas formas de análises sobre as mudanças de uso da terra. Isso também é verdade para a ecologia, que a pouco vem incorporando e aprimorando os modos como os ecólogos pensam a ecologia e conservação em paisagens agrícolas. 
No Brasil, uma mudança como à sugerida acima, ocorreu na biologia da conservação a cerca de 10 anos, quando houve a incorporação do componente agrícola nas pesquisas, pois até então as paisagens agrícolas eram ignoradas em relação ao seu valor conservacionista. Neste contexto surge o Projeto Temático de Pesquisa: Mudanças Socioambientais no Estado de São Paulo: perspectivas para conservação, desenvolvido na Bacia estudada com o intuito de resolver problemas relacionados aos processos econômicos, sociais e ambientais, para manutenção e melhoria dos serviços ecossistêmicos indispensáveis à vida. Especificamente, na linha temática ambiente/sociedade/ruralidade do projeto temático, além deste estudo, outros trabalhos acadêmicos como Fraccaro (2011), Oliveira (2012), Sakaguti Jr (2010) e Silva (2011) e começam incluir o componente social nas pesquisas científicas desenvolvidas na Bacia, considerando fatores históricos e as representações sociais e ambientais. Moran (2011) diz ser esse tipo de ciência integrativa de formação multidisciplinar que fornecerá suporte para que uma nova geração de cientistas lide com os problemas ambientais atuais. A partir dos resultados destas pesquisas podem surgir novas prioridades a serem identificadas, evidenciando a necessidade da incorporação das dimensões humanas nos estudos em paisagens agrícolas.

\subsection{Considerações Finais}

Apesar dos ganhos obtidos com os estudos realizados nos últimos sessenta anos na Bacia do Corumbataí, observamos que existe um grande fosso na pesquisa com relação às dimensões humanas. Avaliamos que os enfoques técnicos-científicos dominantes no campo da conservação dos recursos naturais na Bacia, além dos estudos no meio físico, biótico e abiótico, devem incorporar as dimensões humanas nos processos de conservação da biodiversidade. Ou seja, na prática, a conservação da biodiversidade necessita da inserção e da participação do componente humano local, sendo justamente esta a condição necessária para que a pesquisa continue progredindo, inclusive no sentido de investigar parcelas de uma realidade até então desconsiderada na Bacia Hidrográfica do Corumbataí. De modo geral, é indiscutível o crescimento e a capacidade científica proporcionada pela pesquisa na Bacia e, na medida em que avançam os estudos, os mesmo devem se tornar efetivamente públicos na forma de artigos científicos.

Este estudo sustenta que tomadores de decisão não têm acesso às informações advindas das pesquisas, pois estas estão disponíveis somente por meio de bibliotecas de 
universidades. Fato este, que restringe o acesso à informação para a maioria das pessoas e gestores públicos ou privados. Portanto, os resultados das pesquisas financiadas com dinheiro público devem ser disponibilizados em linguagem acessível, principalmente para os gestores, técnicos e extensionista, facilitando os processos de tomada de decisão relacionados à conservação da biodiversidade local. Uma forma eficiente de atingir essa demanda é atribuir no projeto de pesquisa um recurso para atividade de extensão, onde o operador da pesquisa disponibilizaria os resultados dos artigos em relação à área estudada de forma clara e acessível para comunidade. No entanto, a ideia de um pacote de pesquisa com transferência difusa, como forma de ciência integrativa, necessita de comprometimento, participação em comitês de Bacia, visitas às divisões de meio ambiente municipais, conselhos municipais de meio ambiente, casa de agricultura, participação de eventos regionais pró-ambiente e publicações nos jornais municipais. As contribuições da proposta com relação à disponibilização dos resultados poderiam vir de projetos interdisciplinares de longa duração, formulados com uma concepção humanista e ao seu modo, de caráter extensionista.

\section{Referências}

ANTONIAZZI, L.B. Oferta de serviços ambientais na agricultura. 2008. 91p. Dissertação (Mestrado em Economia Aplicada) - Escola Superior de agricultura "Luiz de Queiroz", Universidade de São Paulo, Piracicaba, 2008.

ARMAS, E.D.; MONTEIRO, R.T.R.; AMÂNCIO, A.V.; CORREA, R.M.L.; GUERCIO, M.A. Uso de agrotóxicos em cana-de-açúcar na bacia do Rio Corumbataí e o risco de poluição hídrica. Química Nova, São Paulo, v.28, n.6, p.975-982, 2005.

ARMAS, E.D.; MONTEIRO, R.T.R.; ANTUNES, P.M.; SANTOS, M.A.P.F.; CAMARGO, P.B. Diagnóstico espaço-temporal da ocorrência de herbicidas nas águas superficiais e sedimentos do rio Corumbataí e principais afluentes. Química Nova, São Paulo, v.30, n.5, p.1119- 1127, 2007.

BEGOSSI, A. Ecologia Humana: um enfoque das relações homem-ambiente. Interciência, Campinas, v. 18, p. 121-132, 1993.

BERKES, F. Sistemas sociais, sistemas ecológicos e direitos de apropriação de recursos naturais. In: VIEIRA, P.F.; BERKES, F.; SEIXAS, C.S. Gestão integrada e participativa de recursos naturais: conceitos, métodos e experiências. Florianópolis: Secco/APED, 2005. p.47-72.

BERKES, F., COLDING, J. , FOLKE, C. Navigating Social-Ecological Systems: Building Resilience for Complexity and Change. Cambridge Univ. Press: Cambridge, UK, 2003. 393 p. 
BERLIN, B. Ethobiological classification: principlis of classification of plants and animal in tradicional societies. Princeton: Princeton University Press, 1992. 335 p.

BORGES, A.K.P.; TAUK-TORNISIELO, S.M.; DOMINGOS, R.N.; ANGELIS, D.F. Performance of the constructed wetland system for the treatment of water from the Corumbataí River. Brazilian Archives of Biology and Technology, Curitiba, v.51, n.6, p.1279-1286, 2008.

CETRA, M.; PETRERE Jr., M. Fish-assemblage structure of the Corumbataí river basin, São Paulo State, Brazil: characterization and anthropogenic disturbances. Brazilian Journal of Biology, São Carlos, v.66, n.2a, p.431-439, 2006.

COMIN, F. H; GARAVELLO, M. E. P. E; GHELER-COSTA, C. Meio Rural da Bacia Hidrográfica do Corumbataí: Interdisciplinaridade, uso e conservação. In: SEMINÁRIO INTERNACIONAL RURALIDADES, TRABALHO E MEIO AMBIENTE,1., 2011, São Carlos. Anais... São Carlos: Editora da UFSCar, 2011. p. 33.

COMIN, F.H; GHELER-COSTA, C.; VERDADE, L.; GARAVELLO, M.E.P.E. Relações e conflitos na conservação ambiental da bacia do Rio Passa-Cinco - São Paulo - Brasil.

OLAM Ciência e Tecnologia, Rio Claro, v. 9, n. 2, p. 254-258, 2009.

COMPANHIA DE TECNOLOGIA DE SANEAMENTO DO MEIO AMBIENTE -CETESB. Relatório de Qualidade das águas interiores no Estado de São Paulo 2008. São Paulo, 2009. Disponível em: http://www.cetesb.sp.gov.br/Agua/Rios/publicacoes.asp.html. Acesso em: 20 ago.2011.

DOTTA, G .; V ERDADE, L.M. Felids in an agricultural landscape in São Paulo Brazil. Cat News, v. 51, n. 6, p.24-27, 2009.

DOTTA, G. ; VERDADE, L.M.T rophic categories in a mammal assemblage: diversity in an agricultural landscape. Biota Neotropica, São Paulo, v.7, n. 2, p. 287-292, 2007.

DOTTA, G.; VERDADE, L.M. Medium to large-sized mammals in agricultural landscapes of South-eastern Brazil. Mammalia, Paris, v. 75, p. 345-352, 2011.

DREW, J. A., HENNE, 2006. Biologia da conservação e conhecimento ecológico tradicional: integrando as disciplinas acadêmicas para uma melhor prática de conservação. Ecology and Society. 11 (2): 34. 2006.

FALQUETO, M.A. Avaliação do índice de qualidade da água (IQA) e dos elementos químicos nas águas e nos sedimentos do rio Corumbataí - SP. 2008. 116p. Dissertação (Mestrado em Ecologia Aplicada) - Escola Superior de Agricultura "Luiz de Queiroz", Universidade de São Paulo, Piracicaba, 2008.

FERRAZ, S.F.D.; PAULA, F.R.; VETTORAZZI, C.A. Incorporation sustainability indicators on site selection for Forest restoration in the Corumbatai River basin. Revista Árvore, Viçosa, v. 33, n. 5, p. 937-947, 2009. 
FRACCARO, L.C.Z. Percepção ambiental e uso de recursos naturais: a população rural de Ipeúna , SP. 2011. 125p. Dissertação (Mestrado em Ecologia Aplicada) - Escola Superior de Agricultura "Luiz de Queiroz", Universidade de São Paulo, 2011.

FUINI, L.L. Estudo do mercado de trabalho em arranjo produtivo local (APL): teritório e produção de cerâmica em Santa Gertrudes, SP. Sociedade e Natureza, Uberlândia, v. 20, p.75-85, 2008.

GHELER-COSTA, C.; VETTORAZZI, C.A.; PARDINI, R.; VERDADE, L.M. The distribution and abundance of small mammals in agroecosystems of southeastern Brazil.

Mammalia, Paris, v.76, p.185 - 191, 2012.

GOMIERO, L.M.; BRAGA, F.M.S. Ichthyofauna diversity in a protected area in the state of São Paulo, southeastern Brazil. Brazilian Journal of Biology, São Carlos, v.66, n.1a, p.7583, 2006.

INSTITUO DE PESQUISAS E ESTUDO FLORESTAIS - IPEF. Plano Diretor:

Conservação dos recursos hídricos por meio da recuperação e da conservação da cobertura florestal da bacia do Rio Corumbataí. Piracicaba: Vitor's Design, 2001. p300

INSTITUTO BRASILEIRO DE GEOGRAFIA E ESTATÍSTICA (IBGE). Censo

Demográfico Brasileiro 2010. Disponível em: http://www.censo2010.ibge.gov.br. html. Acesso em: 10 ago. 2011.

JARDIM, G.M.; ARMAS, E.D.; MONTEIRO, R.T.R. Ecotoxicological assessment of water and sediment of the Corumbataí River, SP, Brazil. Brazilian Journal of Biology, São Carlos, v.68, n.1, p.51-59, 2008.

KUHN, T. A teoria das revoluções científicas. Chicago: University of Chicago Press, 1970. $262 p$.

LIMA-JUNIOR, S.E.; CARDONE, I.B.; GOITEIN, R. Fish assemblage structure and aquatic pollution in a Brazilian stream: some limitations of diversity índices and models for enviornmental impact studies. Ecology of Freshwater Fish, Madri, v. 15, n. 3, p. 284-290, 2006.

LIU, J. et al. Complexity of Coupled Human and Natural Systems. Science, v. 317, p. 15131516. 2007.

MARTINS, R.C. Poder e legitimidade nos enunciados ambientais contemporâneos. Oficina do CES: Centro de Estudos Sociais, 2008. 30p.

MARTINS, R.C. Ruralidade e governança ambiental no Estado de São Paulo. Estudos Sociedade e Agricultura, Rio de Janeiro, v.15, n.2, p.233-267, 2007.

MESSIAS, T.G. Influência da toxidade da água e do sedimento dos rios São Joaquim e Ribeirão Claro na bacia do Corumbataí. 2008. 125p. Dissertação (Mestrado em Ecologia de Agroecossistemas) - Centro de Energia Nuclear na Agricultura, Universidade de São Paulo, Piracicaba, 2008. 
MINGOTI, R.; VETORAZZI, C.A. Relative reduction in annual soil loss in macro watershelds due to the relief and forest cover. Engenharia Agricola, Jaboticabal, v. 31, n. 6, p. 1202-1211, 2011.

MORAIS, E.B.; TAUK-TRONISIELO, S.M.; VENTORINI, S.E. Impacto de atividades agropecuárias na qualidade das águas do rio Cabeça, na bacia do Rio Corumbataí, SP. Holos Environment, Rio Claro, v. 12, n. 1, p. 125-163, 2012.

MORAN, E.F. A ecologia humana das populações da Amazônia. Rio de Janeiro: ed. Vozes. 1990. 335 p.

MORAN, E.F. Meio ambiente e ciências sociais: interações homem-ambiente e sustemtabilidae. São Paulo: Editora SENA, 2011. 307p.

MORAN, E.F., BRONDIZIO, E. S., MCCRACKEN, S. Trajectorias of land use: soils, succession, and crop choice. In: Wood, C. H., PORRO, R. (orgs.). Deforestation and land use in the Amazon. Gainesville: University of Florida Press, 2002.

NOBRE, M.F. O zoneamento ecológico-econômico como instrumento de planejamento e gestão ambiental: uma proposta para a bacia hidrográfica do rio Corumbataí. 2008. 249p. Tese (Doutorado em Geociências) - Instituto de Geociências e Ciências Exatas, Universidade Estadual Paulista,"Júlio de Mesquita Filho" Rio Claro, 2008.

OLIVEIRA, K.A. Estudo da percepção ambiental em torno das entidades gestoras e dos sujeitos envolvidos com políticas e programas de interesse público para o desenvolvimento rural sustentável da bacia do rio Corumbataí com políticas e programas de interesse público para o desenvolvimento rural sustentável da Bacia do Rio Corumbataí. 2012. 99p. Dissertação (Mestrado em Ecologia Aplicada) - Escola Superior de Agricultura “Luiz de Queiroz”, Universidade de São Paulo, Piracicaba, 2012.

PALMA-SILVA, G.M.; TAUK-TORNISIELO, S.M.; PIÃO, A.C. Capacidade de autodepuração de um trecho do rio Corumbataí, SP, Brasil. Holos Environment, Rio Claro, v.7, n.2, p.139-153, 2007.

RIBEIRO, E. M., GALIZONI, F. M. Água, população rural e políticas de gestão: o caso do vale do Jequitinhonha, Minas Gerais. Ambiente \& Sociedade, v.5, no 2, p. 129-146, 2002.

ROMEIRO, A. R., REYDON, B., LEONARDI, M. L. (Org.). Economia do meio ambiente. Campinas: Instituto de Economia/EMBRAPA, 1997.

SAKAGUTI JR, M.M. Significados das paisagens da microbacia do Ribeirão dos Sinos, Ipeúna, SP. 2010. 201p. Dissertação (Mestrado em Ecologia Aplicada) - Escola Superior de Agricultura “Luiz de Queiroz", Universidade de São Paulo, Piracicaba, 2010.

SANTOS, B.S. Um discurso sobre as ciências. São Paulo: Cortez, 2006. 92p.

SCHUBART, O. Os diplópodos de Pirassununga. Acta Zoologica, Jena, v. 2, p. 321-440, 1944. 
SEIXAS, C.S. Abordagens e técnicas de pesquisa participativa em gestão de recursos naturais. In: VIEIRA, P.F.; BERKES, F.; SEIXAS, C.S. (Org.). Gestão Integrada e Participativa de Recursos Naturais. Florianópolis: APED Editora, 2005. p. 73-105.

SILVA, D.L.; CUNHA, C.M.L. Análise morfométrica da bacia do córrego do Lajeado (SP). Caminhos de Geografia, Uberlândia, v.9, n. 26, p.153-172, 2008.

SILVA, M.P. Integração de saberes na gestão dos recursos naturais: caso do município de Ipeúna, SP. 2011. 195p. Dissertação (Mestrado em Ecologia Aplicada) - Escola Superior de Agricultura "Luiz de Queiroz”, Universidade de São Paulo, Piracicaba, 2010.

TAUK-TORNISIELO, S.M. Aspectos Gerais da Bacia do Rio Corumbataí. In: TAUKTORNISIELO, S.M; ESQUIERRO, J.C. (Org.). Bacia do Rio Corumbataí: Aspectos socioeconômicos e ambientais. Piracicaba: Consórcio PCJ. 2008. p. 102-125.

TAUK-TORNISIELO, S.M. Unidade de pesque-pague na bacia do rio Corumbataí, diagnóstico socioeconômico ambiental e tratamento de efluentes. Holos Environement, Rio Claro, v. 11, n. 1, p. 31-43, 2011.

TAVARES, A.C.; CHISTOFOLETTI, A.L.H.; SANTANA, M.P.C. Tipos de tempo e feições do escoameto superficial na bacia do rio Corumbataí - SP, Brasil. Climatologia e Estudo da Paisagem, Rio Claro, v.2, n.1, p.128-147, 2007.

THOMAS Jr., W. L. Man's Role in Changing the Face of the Earth. Univ. of Chicago Press: Chicago, IL, 1956.

TURNER II, B. L., CLARK, W. C., KATES, R. W., RICHARDS, J. F., MATHEWS, J.T., MEYER, W.B. The Earth as Transformed by Human Action: Global and Regional Changes in the Biosphere over the Past 300 Years. Cambridge Univ. Press: Cambridge, UK, 1990. 732p.

VALENTE, R.O.A; VETTORAZZI, C.A. Avaliação da estrutura florestal na bacia hidrográfica do Rio Corumbataí, SP. Scientia Florestalis, Piracicaba, n.68, p.45-57, 2005.

VALENTE, R.O.A; VETTORAZZI, C.A. Definition of priority areas for forest conservation through the Ordered Weighted Averaging method. Forest Ecology and Management, Amsterdam, v. 256, p.1408-1417, 2008.

VITOUSEK, P. M., MOONEY, H. A. , LUBCHENCO, J., MELILLO, J. M. Human Domination of Earth's Ecosystems. Science, Washington, v. 277, p. 494-499, 1997.

ZAMBETA, P.M.A. Espécies químicas inorgânicas (Al, As, Cd, Cr, Cu, Fé, Hg, Mn, Ni, Pb e Sn) no sedimento e nos sólidos em suspensão do rio Corumbataí, SP. 2006. 73p. Dissertação (Mestrado em Ecologia de Agroecossistemas) - Centro de Energia Nuclear na Agricultura, Universidade de São Paulo, Piracicaba, 2006. 


\title{
3 RELAÇÃO ENTRE AGRICULTURA FAMILIAR E MEIO AMBIENTE EM PAISAGENS AGRÍCOLAS: ÁREA DE PROTEÇÃO AMBIENTAL DO CORUMBATAÍ, ESTADO DE SÃO PAULO - BRASIL
}

\section{Resumo}

A Bacia hidrográfica do Corumbataí tem importância regional em função de ser o principal manancial de abastecimento da região centro-leste do estado de São Paulo. Estudos realizados na paisagem agrícola desta região priorizam os remanescentes florestais, a hidrologia, as matas ciliares, a matriz agrícola, a fauna e suas relações e, muitas vezes consideram a população rural como causadora dos danos ambientais, seja pelas práticas agrícolas inadequadas ou pela degradação ambiental provocada pelo uso indiscriminado dos recursos. Com intuito de conservar o ecossistema principalmente, relacionados às questões hídricas, muitos trabalhos de cunho ecológico propõem como alternativas o fortalecimento de políticas públicas, corredores florestais, educação ambiental ou o simples cumprimento das leis ambientais. No entanto, entendemos que, sem incluir a população rural nas pesquisas de cunho ambiental, não há como garantir a conservação na prática. Uma vez que consideramos as comunidades rurais, principalmente da agricultura familiar, como as protagonistas nas ações de degradação e conservação local, focalizamos neste estudo a necessidade de sua inserção nas propostas de conservação, considerando-as como elemento integrante do agroecossistema. Através de uma pesquisa interdisciplinar assumimos o caráter utilitário das relações dos moradores do meio rural com as questões ambientais, principalmente hídricas, e como esta relação pode ser incorporada às propostas de conservação para enfrentar a atual crise "ecológica" na Bacia. Os resultados revelam que estudos sobre a relação da população rural da Bacia do Corumbataí com o ambiente são de extrema relevância para compreender a relação do homem com a natureza em paisagens agrícolas no estado de São Paulo, e para que a conservação seja realizada na prática.

Palavras-chave: Corumbataí; População rural; Agricultura familiar; Conservação

\begin{abstract}
The basin Corumbataí has regional importance because of being the main source of supply of central-eastern state of São Paulo. Studies conducted in the agricultural landscape of this region prioritize the remaining forests, hydrology, riparian forests, the agricultural matrix, fauna and their relationships, and often consider the rural population to cause environmental damage, either by inadequate agricultural practices or by degradation environment caused by the indiscriminate use of resources. In order to conserve the ecosystem mainly related to water issues, many studies of ecological alternatives propose the strengthening of public policies, forest corridors, environmental education or mere compliance with environmental laws. However, we understand that, not including the rural population in search of an environmental
\end{abstract}


nature, there's no guarantee the conservation practice. Since we consider rural communities, particularly family farms, as the protagonists in the actions of degradation and conservation site, we focus in this study the need for their involvement in conservation proposals, considering them as an integral part of the agro ecosystem. Through an interdisciplinary research assume the utilitarian character of the relations of the inhabitants of rural areas with environmental issues, especially water, and how this relationship can be incorporated into conservation proposals to address the current "green" crisis in the basin. The results show that studies on the relationship of the rural basin Corumbataí with the environment are extremely important to understand the relationship between man and nature in agricultural landscapes in the state of São Paulo, and that conservation is carried out in practice.

Keywords: Corumbataí; Rural population; Family farming; Conservation

\subsection{Introdução}

O tema central deste estudo trata da interação entre as dimensões humanas e a conservação da biodiversidade em uma paisagem agrícola do interior do estado de São Paulo. Para entender estas interações, a Bacia do Corumbataí $\left(1.710 \mathrm{~km}^{2}\right)$ foi utilizada como região modelo para todo o estado de São Paulo. Esta Bacia pertence à Unidade de Gerenciamento de Recurso Hídricos número 5 (URGH 5), conforme previsto no Sistema Integrado de Gerenciamento de Recursos Hídricos (SIRGH, Lei 7633/81), e é considerada área prioritária para conservação dentro do Sistema Piracicaba, Capivari, Jundiaí (PCJ). A região é reconhecida como produtora de água para uma população de quase 1 milhão de pessoas (NOBRE, 2008).

Especificamente, este estudo amostrou a Área de Proteção Ambiental Corumbataí (APA Corumbataí - Decreto Estadual 20960/86). A escolha da APA se deu por esta ter legislação própria e ser uma categoria reconhecida pelo Sistema Nacional de Unidades de Conservação - SNUC (Lei 9985/00). A função de uma APA é garantir a manutenção da propriedade, neste caso rural, desde que ela cumpra sua função social e os princípios da conservação ambiental. Portanto, uma região representativa para toda Bacia Hidrográfica do Corumbataí.

Tanto na Bacia do Corumbataí, quanto na APA do Corumbataí, as populações rurais, como a biodiversidade têm se modificado em função dos processos de uso e ocupação do solo. Assim, o entendimento das atividades, conhecimentos e vivência do produtor rural da região, são de fundamental importância, tanto para a sua permanência no campo, como para a real conservação dos recursos naturais na região. 
A APA do Corumbataí é um espaço ideal para estudos sobre a problemática da conservação ambiental no passado e no presente, devido ao acúmulo de informações disponíveis de diferentes áreas do conhecimento, principalmente os relacionados às ciências naturais e de fatores abióticos como água e solo (CUNHA, 2008; DOTTA; VERDADE, 2007, 2009, 2011; CARMASSI et al., 2012, GHELER-COSTA et al., 2012, FERRAZ et al., 2009, JARDIM et al., 2008, MORAIS et al., 2012, PALMA-SILVA et al., 2007, SILVA; SILVERIA et al., 2008, ZUQUETTE et al., 2009). No entanto, pouco se conhece sobre as interações homem-natureza na região, e muito menos sobre qual a situação da população rural frente a este cenário de degradação ambiental pela qual a Bacia do Corumbataí vem passando ao longo do tempo. Dessa forma, o corpo central deste estudo busca resultados de um complexo processo de entendimento da interação da sociedade com a natureza, com vistas à conservação socioambiental.

O conceito de interação aqui adotado tem o caráter de ação recíproca, podendo ainda ser concebido por seu caráter estritamente ecológico, que integra tanto os indivíduos quanto os ecossistemas, mais precisamente, quando um indivíduo influencia a vida de outros (BEGON et al., 2007, p.223). O termo conservação utilizado segue o sugerido pela Convenção da Diversidade Biológica (Decreto Federal 2519-98), que remete exclusivamente à diversidade biológica, componente básico da qualidade ambiental (CDB, 1998). A convenção traz ainda que, as dinâmicas políticas e sociais reforçam o caráter socioambiental da conservação.

Atualmente vem sendo preconizado que não apenas áreas de relevante interesse, tais como os fragmentos florestais com grande extensão ou unidades de conservação, merecem atenção de políticas para conservação da biodiversidade, mas que o todo, ou seja, a matriz deve estar inscrita nestas políticas (DOTTA; VERDADE, 2007, 2009, 2011; GHELERCOSTA et al., 2012; JOLY et al., 2011, PERFECTO et al., 2009). Dessa maneira, no ambiente agrícola do estado de São Paulo uma das formas de assegurar a conservação ou a redução das perdas de biodiversidade é incorporar as dimensões humanas nas questões de conservação e manutenção de serviços ecossistêmicos, já que estes também estão inseridos na matriz agrícola.

Nesse sentido, as dimensões humanas são aqui definidas como o comportamento e as ações das pessoas, incluindo as estratégias de manejo sobre o solo e o ambiente. Esta definição procura integrar as ciências sociais e ecológicas, gerando uma compreensão mais ampla a respeito das questões referentes à conservação (JACOBSON; McDUFF, 1998). Segundo Youné e Garay (2006 p.57), sem a correta compreensão da complexidade destas 
questões e, principalmente, sem considerar as interações humanas, a implementação de políticas públicas de cunho ambiental torna-se inviável. Fitzgerald e Stronza (2009), afirmam que a compreensão da dimensão humana promove habilidades para responder à variedade de interesses sociais, científicos e políticos na conservação da natureza. Algumas destas dimensões são tratadas por Jacobson et al. (1998) como atitudes, valores, comportamento, características socioeconômicas e demográficas, que devem integrar as ciências sociais e a ecologia para a interdisciplinaridade da conservação. Para esses autores, as soluções para a crise da biodiversidade no campo serão geradas a partir do trabalho conjunto entre cientistas naturais e sociais. De acordo com Moran (2011), o caráter multidisciplinar pode ajudar a entender os fatores das perdas da biodiversidade em paisagens agrícolas, e este se encontra no campo da ciência da sustentabilidade, ou pesquisa das dimensões humanas das mudanças globais.

No Brasil, ainda que muitos estudos venham atuando com a temática das dimensões humanas nas políticas públicas e conservação da biodiversidade, estes geralmente são desenvolvidos em escalas maiores, tendo como universo de inferência os biomas Mata Atlântica, Amazonas e Cerrado (BALÉE, 2006; CARNEIRO et al., 2009; DINIZ-FILHO et al., 2009; FERREIRA, 2004; GARAY; BECKER, 2006), e muitos desses trabalhos incluem ainda questões relacionadas apenas às populações tradicionais.

Em escala local, na Bacia do Corumbataí, os moradores do meio rural são atores que desempenham um importante papel na manutenção ou não das questões de conservação do ecossistema local, e que ainda se relacionam com o meio natural através de suas práticas agrícolas e do uso e exploração dos recursos hídricos. Por sua vez, os mesmos recursos hídricos que são o alvo prioritário das pesquisas realizadas na Bacia e de ações conservacionistas. No entanto, é pouco ou quase inexistente a participação ou a inserção dos moradores do meio rural em propostas de pesquisas de cunho ambiental conservacionista. $\mathrm{Na}$ maioria das vezes esta população não é nem ao menos considerada como parte integrante da paisagem, seja pela dificuldade de encontrar mecanismos que permitam sua inserção e participação nos processos de pesquisa, seja pela supremacia e pensamento equivocado daqueles que acreditam que tais populações são entraves para a conservação dos recursos naturais de fato. Soulé (1985) considera que para que haja conservação de fato, é necessário entender primeiro os efeitos da atividade humana no ecossistema. Sendo, nesse sentido, para entender os efeitos da atividade humana, há de se conhecer esse grupo. De modo geral, são poucos os trabalhos envolvendo a questão do rural na Bacia do Corumbataí, sendo alguns relacionados à estrutura socioeconômica (ANTONIAZZI, 2008; FUINI, 2008; GARCIA, 
2000; NOBRE, 2008), e outros relacionados ao conhecimento local e meio ambiente (COMIN et al., 2009; COMIN et al., 2011; MAMED-COSTA et al., 2006). Recentemente, o projeto temático de pesquisa "Mudanças Sócio-ambientais no Estado de São Paulo e Perspectivas para Conservação" (Biota/Fapesp) resultou em mais um significativo esforço de pesquisa na Bacia, incluindo o presente estudo.

Martinelli e Filoso (2009) consideram que a agricultura somente existe onde os ecossistemas são capazes de manter suas funções básicas de funcionamento, e assim, os serviços ambientais prestados pelos ecossistemas de modo geral devem ser valorizados. Segundo Younés (2001 p. 40), uma vez que os seres humanos desempenham papel chave na alteração dos processos ecossistêmicos, a integração das atividades humanas com os ecossistemas é crucial para consolidar os esforços de conservação dos componentes da biodiversidade. Além disso, é considerável pensar que os serviços ecossistêmicos são mantenedores dos processos ecológicos e também dos processos evolutivos. Para Vieira (2005 p. 335), essa é uma linha de pesquisa que aproxima o entendimento de como e, em que sentido certas condições da dinâmica de funcionamento dos sistemas ecológicos influenciam a dinâmica de funcionamento dos sistemas sociais, e também, como e por que certas condições sociais (em sentido amplo) tendem a impactar mais ou menos os processos ecológicos essenciais e, por implicação, as chances de preservação da resiliência de sistemas sócioecológicos.

Considerando os aspectos gerais das interações das dimensões humanas na conservação da biodiversidade, observamos que as transformações ocorridas na Bacia do Corumbataí nos últimos anos resultaram não apenas em perda de biodiversidade, causando consequências diretas e inevitáveis no seu conjunto, mas também comprometem o pequeno produtor rural, colocando-o como uma população em declínio, em vias de extinção local. É pertinente destacar aqui que concordamos com Lamarche $(1993,1998)$ quando rejeita toda visão evolucionista, daqueles que consideram a agricultura familiar como forma social residual, transitória ou em vias de desaparecimento. Sugere ainda que, o espaço ocupado por essa forma social de agricultura vem resistindo e se transformando, demonstrando capacidade de adaptação da agricultura tipo familiar (SILVA, 1999), que nos dias de hoje reforça o entendimento das relações desse grupo com as questões ambientais.

Face ao exposto, a seguinte hipótese nula foi testada: a relação entre as formas de uso da terra dos pequenos proprietários e o ambiente não leva em conta a conservação dos recursos hídricos nem as áreas de preservação permanente e de reserva legal. Os objetivos deste estudo foram: a) Descrever a relação entre os pequenos proprietários e o ambiente na 
APA do Corumbataí, e b) Entender os processos de conservação da paisagem agrícola e a contribuição da agricultura familiar sob a luz das pesquisas socioambientais.

Esta problemática foi analisada por meio de um estudo de caso realizado com recursos e técnicas qualitativas de pesquisa social nos segmentos agrícolas dos municípios de Ipeúna, Analândia e Corumbataí, no estado de São Paulo. Pretende-se de forma geral, investigar o papel do agricultor familiar na conservação da região, inseri-los na pesquisa e, demonstrar as dificuldades encontradas por estes para produzir espécies domesticadas, garantir sua reprodução sociocultural e formas de participar na conservação do meio ambiente.

\subsection{Desenvolvimento}

\subsubsection{Revisão}

De modo geral, a maioria das classificações sobre agricultura familiar no Brasil são pautadas na lei $\mathrm{n}^{\mathrm{o}}$ 8.629/93 de 25 de fevereiro de 1993, a chamada lei Agrária, que no artigo $4^{\mathrm{o}}$ regulamenta e define a pequena propriedade como sendo a área compreendida entre um e quatro módulos fiscais. Módulo fiscal é uma unidade de medida expressa em hectares e estabelecida a partir das aptidões agrícolas de cada município, considerando: tipo de exploração predominante; renda obtida com a exploração predominante; outras explorações existentes no município que, embora não predominantes, sejam significativas em função da renda ou da área utilizada, além do conceito de propriedade familiar. A medida provisória $\mathrm{n}^{\circ}$ 2.166-67 de 24 de agosto de 2001, define a pequena propriedade familiar como aquela explorada com o trabalho pessoal do proprietário ou do posseiro e de sua família, admitida a ajuda eventual de terceiro, e cuja renda bruta seja proveniente, no mínimo em $80 \%$, de atividade agrícola, agroflorestal ou de extrativismo e, cuja área não supere 30 ha no estado de São Paulo ( $\$ 2^{\circ}$ do artigo $1^{\circ}$ da lei $\left.n^{\circ} 4.771 / 1965\right)$.

A lei $\mathrm{n}^{\circ} 11.326$, de 24 de julho de 2006, estabelece as diretrizes para a formulação da política nacional da agricultura familiar e empreendimentos familiares rurais, considerando que estes não detenham a qualquer título, área maior que 4 módulos fiscais, que utilize predominantemente mão-de-obra da própria família nas atividades econômicas do seu estabelecimento ou empreendimento, que tenha renda familiar predominantemente originada de atividades econômicas vinculadas ao próprio estabelecimento, e que dirija seu estabelecimento com sua família. Coexiste ainda, a resolução SAA-17, de 11 de julho de 2005 (IMESP, 2005) que classifica os pequenos produtores rurais como aqueles que possuem área 
total explorada de até 50 ha e $70 \%$ no mínimo de sua renda familiar proveniente da agropecuária, e resida na propriedade ou no município onde está localizada a propriedade ou em município vizinho. No mesmo sentido da lei 8.629, a lei $\mathrm{n}^{\circ} 9.393$, de 19 de dezembro de 1996, fixa para a pequena propriedade rural a dimensão de 30 hectares quando localizada na região Sul e Sudeste.

Dito isso, a agricultura familiar no Brasil responde por cerca de $30 \%$ do PIB do setor agropecuário, uma vez que cerca de $30 \%$ de toda a terra agricultável está sob a posse de agricultores familiares, contribuindo em escala mundial em cerca de 30-50\% para a segurança alimentar (ALTIERI, 2004). Considerando todos os aspectos da cultura material, a alimentação é o que mais se encontra subjacente a toda esfera da atividade humana. De acordo com Carneiro (2003), as histórias das civilizações e da utilização vegetal se confundem. Se incluirmos o consumo de carnes e outros derivados de animais, verifica-se que a história da alimentação tem como objeto quase toda a natureza viva no âmbito universal de todas as épocas, povos e cultura, desde o período de caça e coleta, do desenvolvimento da agricultura, até a indústria moderna. Para Fischler (1988) os alimentos representam a ligação mais primitiva entre natureza e cultura, fazendo parte da raiz que liga um povo, uma comunidade ou um grupo ao seu território.

No estado de São Paulo a agricultura familiar ocupa uma área com mais de 2 milhões de hectares, e na Bacia do Corumbataí especificamente nos municípios estudados (Analândia, Ipeúna e Corumbataí) compreende uma área com cerca de 7 mil hectares, produzindo alimentos e serviços ambientais. Por isso ressalta-se o papel da agricultura familiar e suas supostas relações com a conservação ambiental e a preservação dos recursos naturais nesta região, além da prestação de serviços ecossistêmicos, podendo contribuir para a melhoria das condições ambientais e da qualidade de vida tanto destes agricultores quando ao meio ambiente de forma geral.

Ao falarmos de serviços ambientais ou serviços ecossistêmicos nos estabelecimentos rurais da agricultura familiar, não podemos renegar que estes estão diretamente associados à temática da conservação ambiental. Sabe-se que a agricultura familiar desenvolve conhecimentos próprios, capazes de permitir a combinação entre produção agrícola e preservação do meio ambiente, sabe-se da mesma forma que a domesticação e cultivo de espécies estão intimamente ligados ao uso e manejo do ambiente natural (THOMAS, 2010). De tal modo, a diversidade em uma unidade produtiva, seja ela em qualquer região do país, pode favorecer a geração de serviços ambientais, uma vez que, com uma maior diversidade de espécies, essas áreas possibilitam um número maior de sistemas naturais, que auxiliarão na 
recuperação do ecossistema como um todo (GUILLHOTO et al., 2004). É neste sentido que entendemos a multifuncionalidade da agricultura na conservação de ecossistemas de interesse. A questão da multifuncionalidade ambiental da agricultura será abordada posteriormente.

O que estamos querendo dizer é que a relação que os agricultores familiares estabelecem com os recursos naturais, em especial as florestas e a água, apresentam formas que variam da total dependência econômica e sociocultural, além da substituição da cobertura vegetal nativa para a implantação de lavouras e pastagens. Esta constatação é muito nítida, por exemplo, na região amazônica, onde alguns autores têm demonstrado essa relação como positiva (BRONDIZIO; MORAN, 2008; BERKES et al., 2003). A nosso ver e levando sempre em consideração as diferenças culturais e sociais de cada local, as unidades produtivas empreendem um complexo sistema de atividades envolvendo áreas de roça, capoeira ou áreas de pousio, reserva legal, quintais, extrativismo vegetal ou animal e a criação de animais domésticos (HOMMA, 2006). Especificamente na Bacia do Corumbataí, nas unidades da agricultura familiar, as atividades produtivas estão voltadas à produção do feijão, arroz, algodão, alho, milho, leite, carne, processados, destilados, fermentados, avicultura, hortaliças, verduras e atendem principalmente à demanda local desses bens, que é culturalmente bem aceita. Embora exista no Brasil e no mundo uma diversidade de situações relacionadas à agricultura familiar, podendo haver problemas diferentes em determinadas regiões, quando observamos o cenário como um todo, verificamos que os agricultores familiares, tanto da Bacia, quanto em outros países, apresentam características muito similares, com pouco acesso a tecnologia, pouco acesso ao crédito, baixa renda mensal, empregos não agrícolas, e o mais importante, vontade de permanecer na terra, mesmo com tantas dificuldades (BRONDIZIO: MORAN, 2008).

Muitos autores têm apontado que grupos ou comunidades de agricultores familiares estão adaptados ao meio em que vivem (MARTINS, 2006, BRONDIZIO; MORAN, 2008; MOREIRA, 2008), adaptados aos recursos que exploram e à cultura que construíram, por isso são eficientes gestores dos recursos naturais, além de, serem capazes de criar técnicas sustentáveis de produção e normas eficazes de gerenciamento do meio. Como vivem próximos ao meio que exploram, elaboraram um complexo conhecimento sobre os recursos e sua conservação (ALMEIDA, 1988; DIEGUES, 1996; GALIZONI, 2000; COLCHESTER, 2000). Todavia isso geralmente ocorre em regiões onde os componentes ambientais são melhores ou mais preservados, mas a Bacia do Corumbataí apresenta uma paisagem altamente degradada (MARINO, 2006), sendo os ambientes naturais fragmentados, isolados, com baixa complexidade estrutural. Atualmente, a paisagem da Bacia contempla $42 \%$ de áreas com 
pastagens, 28\% cana-de-açúcar, $12 \%$ florestas nativas, $6 \%$ silvicultura, 5\% fruticultura e culturas anuais, $4 \%$ rede hidrográfica, $3 \%$ área urbana, malha viária e mineração (VALENTE, 2005; CEAPLA, 2013). Nesse caso, a preocupação com suas funções ecológicas estão intimamente relacionadas à proteção dos recursos hídricos, alvo prioritário de conservação, uma vez que a Bacia é responsável pelo abastecimento hídrico de mais de um milhão de pessoas.

Ainda em relação ao uso da terra na região da Bacia do Corumbataí, o arrendamento das terras para o plantio de cana-de-açúcar vem aparecendo como uma oportunidade para as pequenas e médias propriedades em virtude do valor contínuo arrecadado, e para as grandes propriedades existem indicações pela substituição das pastagens para o plantio do eucalipto (Comin, 2007). Esta evolução aparece também nos resultados de Marino (2006) que confirmam os relatos de Garcia (2000) a respeito do desenvolvimento agropecuário regional. Por sua vez, a preocupação com a comunidade da agricultura familiar parece estar deixada de lado, contrariando a lógica e a importância deste grupo com os serviços ambientais produzidos por eles na Bacia. Além disso, a região é alvo de ações voltadas à conservação ambiental, uma vez que as áreas de preservação permanente (APP) e as reservas legais (RL) são os principais depositários e mantenedores de biodiversidade em paisagens agrícolas. Da mesma forma, pouco se sabe sobre estes elementos (APP e RL) nas unidades da agricultura familiar na bacia e seu papel crucial na conservação como visto anteriormente. De modo geral, é possível constatar que na Bacia do Corumbataí, os esforços, bem como as pesquisas na temática conservação ambiental da paisagem agrícola e as políticas ambientais, ainda não se despertaram para algumas relações intrínsecas no âmbito de entendimento e junção de esforços para conservação da natureza e das dimensões humanas. Aparentemente em uma região altamente desenvolvida pelo seu histórico agropecuário, rica, produtiva e com imposições severas da legislação ambiental, os serviços ambientais e ecossistêmicos estão sendo perdidos. Essa é uma situação similar àquelas encontradas em novas áreas de expansão agrícola no norte do país. Em função dessas constatações, se revela a importância do estudo da agricultura familiar e conservação ambiental com as famílias de agricultores que residem em áreas rurais da Bacia.

Até o momento, em uma das Bacias Hidrográficas mais estudadas no país, a temática entre serviços ecossistêmicos e dimensões humanas, neste caso agricultura familiares, foi pouco explorada. Portanto entender o papel dos proprietários rurais e a dificuldade de permanecerem no campo é necessário para mostrar a importância da dimensão social na questão ambiental. Os estudos nesse campo nos ajudam a compreender melhor como as 
pessoas utilizam as informações a respeito do ambiente e com isso entender questões importantes para os estudos homem-ambiente (BRONDIZIO; MORAN, 2008; MORAN, 2001).

$\mathrm{Na}$ sociologia rural as pesquisas referentes à agricultura familiar têm fortes relações filosóficas advindas da escola francesa de ciências sociais de caráter multifuncionalista, e trouxe a luz os conceitos de multifuncionalidade da agricultura, que se refere ao "conjunto das contribuições da agricultura para um desenvolvimento econômico e social considerado na sua globalidade" (LAURENT, 1999). Este conceito remete necessariamente a declaração estruturada durante a Conferência das Nações Unidas sobre meio Ambiente e Desenvolvimento em 1992. Foi, portanto, a partir deste momento que a multifuncionalidade da agricultura passa a ser reconhecida pela sociedade como interesse público ou geral por suas funções sociais, ambientais, econômicas ou culturais, não diretamente produtivas, e associadas à atividade agropecuária. Logo, a manifestação da multifuncionalidade da atividade agropecuária em termos de políticas agrícolas teve início, principalmente na Europa como "o conjunto das funções devolutas aos agricultores, reconhecidas pela coletividade e podendo beneficiar da implementação de apoios públicos" (LAURENT, 1999). Desta forma, a multifuncionalidade passa a remete-se necessariamente à valorização, a preservação e a continuidade das interações sociais, ambientais e econômicas, associadas à produção agrícola (SABOURIN, 2008), garantindo assim a reprodução das relações humanas, das estruturas socioeconômicas e dos valores a elas associados (BARTHÉLÉMY, 2003). Atualmente, a adoção e a difusão da multifuncionalidade da agricultura na Europa estão associadas a uma estratégia de alocação individual e contratual de recursos públicos aos agricultores, para que sejam retribuídas as funções sociais e ambientais de interesse público associado à produção (FAO, 1999, CAZELLA; MATTEI, 2002; MALUF, 2002).

No Brasil, apesar de existirem pesquisas e interesse sobre a multifuncionalidade da agricultura (MDA, CAMPANHOLA, 2003, SABOURIN, 2008), os instrumentos de uma política de multifuncionalidade ainda não são comuns. Mesmo assim, tanto na América Latina, como nos países da América do Sul, algumas atribuições da multifuncionalidade da agricultura vêm sendo aplicadas e relacionadas aos pagamentos de serviços ambientais, em particular o sequestro de $\mathrm{CO}_{2}$, por meio de projetos florestais, agro-florestais ou silvo-agropastorais, como visto na Costa Rica, ou como produtores de água em Extrema - MG e Joanópolis - SP (SABOURIN, 2008, EXTREMA, 2005, RODRÍGUEZ; SÁENZ, 2002, ROSA et al., 2003). A partir deste exemplo, a multifuncionalidade da agricultura para além da produção, passa a tomar projeção no cenário nacional sobre a constatação de que a 
agricultura tem se modificado, assumindo diferentes configurações para além da produção agrícola para renda, cuja importância varia segundo as regiões e os ecossistemas naturais.

Segundo Bonnal et al., 2003 a multifuncionalidade da agricultura se refere ao conjunto de serviços e produtos criados pela atividade agrícola, que têm um impacto direto ou indireto sobre a economia, a sociedade e a natureza. Segundo Wanderley (2003, p. 09), ao romper com a hegemonia exclusiva da "função" econômica, o enfoque multifuncional da unidade produtiva pode propiciar o entendimento do agricultor em suas complexas relações com a natureza. Em se tratando de natureza e conservação ambiental, Maluf (2003) diz que a multifuncionalidade ambiental na maioria das vezes é desconsiderada pelos analistas do meio rural. De tal modo, neste estudo, a adoção de análise da multifuncionalidade implica em reconhecer as funções econômicas, sociais e principalmente ambientais da agricultura familiar na Bacia, possibilitando o entendimento das dimensões humanas relativas às estratégias de reprodução social e conservação ambiental. Deste modo, a ênfase dada à multifuncionalidade da agricultura familiar e suas relações com o ambiente, também pode fortalecer a conservação dos recursos naturais. Portanto, neste trabalho as considerações sobre a multifuncionalidade ambiental da agricultura familiar pode representar uma tentativa de reconhecer as unidades produtivas, não apenas como produtoras de bens agrícolas ou sociais, mas se ampliam também para o campo de suas funções ambientais, tendo em vista, a conservação ambiental da Bacia.

Até o momento esta revisão trouxe elementos complexos e distintos, tratando de duas temáticas que estão tão próximas e ao mesmo tempo tão distantes das reais necessidades e possibilidades para a Bacia. Se por um lado as pesquisas da temática ambiental apontam para a urgência da conservação ambiental, por outro, ela não atenta para as dimensões humanas. Da mesma forma, as robustas bases sociológicas das teóricas da multifuncionalidade na agricultura, ainda não estão incorporadas ou mesmo sendo aplicadas na Bacia produtora de bens alimentícios e serviços ambientais. Considerar a perspectiva da multifuncionalidade ambiental nesse contexto implica, em reconhecer e considerar algumas possibilidades das diferentes funções da agricultura familiar na Bacia do Corumbataí, com vista à sua conservação socioambiental. Seja como produtores de alimentos para consumo humano e para a alimentação da renda ou como contribuição à viabilidade das áreas rurais e a um desenvolvimento econômico equilibrado do ponto de vista territorial rural, ou ainda, na a defesa os valores paisagísticos e do meio ambiente conforme sugere Martinez, 2001. Segundo Portugal (2004) atender as demandas da agricultura familiar é um desafio para que a uma sociedade mais justa e harmoniosa seja criada e difundida. Segundo o mesmo autor existem 
dois fatores fundamentais para o desenvolvimento da agricultura familiar: a) massificação das informações organizadas e adequadas usando meios de comunicação em massa; e b) melhoria da capacidade organizacional dos produtores, buscando entre outras coisas agregar valor à produção ambiental e agrícola da agricultura familiar.

Nesse sentido, passou a tomar projeção a constatação de que a agricultura tem se modificado, assumindo diferentes configurações para além da produção agrícola para renda, cuja importância varia segundo as regiões e os ecossistemas naturais. Em contextos internacionais, a dinâmica da produção agrícola no espaço rural, vem sendo condicionada e determinada por outras atividades, passando a ser cada vez mais percebida como uma das dimensões estabelecidas entre a sociedade e o espaço ou entre o homem e a natureza.

Portanto, neste estudo a adoção de tal instrumento de análise - a multifuncionalidade ambiental da agricultura familiar - implica em reconhecer e diagnosticar as funções econômica, ambiental e social da agricultura familiar na bacia hidrográfica do Corumbataí, para a manutenção das sociedades rurais e conservação ambiental. Trata-se, de refundar as relações entre o econômico, o social, o ambiental e os processos tecnológicos. Sugerimos, portanto, que é possível desenvolver um campo teórico sobre a multifuncionalidade ambiental da agricultura familiar na paisagem agrícola, como forma de entendimento da dinâmica da população rural em face da conservação da natureza, sendo estes os pilares que sustentam a proposta interdisciplinar deste estudo. Segundo Moran, 2005, enfrentar esse desafio é uma tarefa difícil, e requer que baixemos a guarda e tenhamos as ferramentas, as teorias e os métodos certos para as perguntas que estão sendo formuladas, independente das disciplinas de onde elas vieram. Diz ainda ser uma tarefa desafiadora com perspectivas de uma nova via de pesquisa e, vai além, diz ser este o tipo de pesquisa que sem deixar o rigor científico, responde às perguntas da sociedade e não somente as dos cientistas acadêmicos. Em outras palavras o autor nos mostra que o caminho à frente é uma ciência integrativa do homem com o ambiente, da constatação empírica e a contribuição científica, da politica até aqueles que a manejam a terra, já que nosso entendimento está muito atrasado no tocante aos processos mencionados anteriormente. Algumas dessas constatações aparecerão nas discussões dos resultados desta tese.

Dessa forma, o que foi exposto até o momento revela a existência de uma problemática sócio-ambiental na Bacia e neste caso estamos sugerindo um estudo integrando elementos da agricultura em relação ao meio ambiente para a conservação de paisagens agrícolas. De certo modo, o que estamos propondo estabeleceria um marco para os estudos na Bacia Do Corumbataí com a valorização das compensações mútuas e sinergias entre 
as diferentes funções da agricultura e o correspondente uso da terra, justificando assim o esforço e as proposituras apresentadas neste estudo.

\subsection{2 Área de estudo}

A Bacia hidrográfica do Corumbataí está localizada entre os paralelos $22^{\circ} 04^{\prime} 46^{\prime \prime} \mathrm{e}$ $22^{\circ} 41^{\prime} 28^{\prime \prime}$ e os meridianos $47^{\circ} 26^{\prime} 23^{\prime \prime}$ e $47^{\circ} 56^{\prime} 15^{\prime}$ ' na região Centro-Leste do Estado de São Paulo (IPEF, 2001). O rio Corumbataí tem sua principal nascente no município de Analândia,

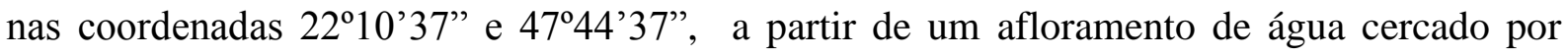
vegetação ripária pouco conservada, e sua área de preservação permanente está comprometida pelo uso da terra no entorno, que é uma extensa área com plantio de cana-de-açúcar. A nascente está a 460 metros de altitude e drena uma área de $160 \mathrm{~km}^{2}$, e após receber os tributários Ribeirão Cabeça, Ribeirão Passa-Cinco e Ribeirão Claro, têm sua foz a 136 km da nascente alimentando o rio Piracicaba (IPEF, 2001). Ao longo do seu curso vem servindo além de fonte de abastecimento, como corpo de água receptor de resíduos industriais e domésticos. Segundo dados da Companhia de Tecnologia de Saneamento Ambiental do Estado de São Paulo - CETESB (2007a, 2007b) a Bacia do Corumbataí conta com quase 600.000 habitantes (597.727) e apenas $43 \%$ da carga poluidora recebe algum tratamento.

Os municípios que compõe a Bacia do rio Corumbataí pertencem à UGRHI PCJ (URGHI 5 do Estado de São Paulo). O Instituto de Pesquisas e Estudos Florestais - IPEF (2001) define cinco sub-bacias dentro da Bacia do Corumbataí (Alto, Médio e Baixo Corumbataí, Passa-Cinco e Rio Claro). O clima na região é caracterizado como subtropical, com sazonalidade bem definida sendo, seco no inverno, com temperatura média na casa dos $17^{\circ} \mathrm{C}$ e chuvosa no verão, com temperatura média de $22^{\circ} \mathrm{C}$ (SALATI, 1996; CEAPLA, 2013). Suas características geomorfológicas são predominantes da era Cenozóica, com as cabeceiras nas cuestas da Serra Geral, típica da bacia sedimentar do Paraná, apresentando quatro formações geológicas tais como, Piranbóia, Rio Claro, Irati e Corumbataí (KOFFLER, 1993,1994). O mesmo autor classifica o relevo da Bacia com presença de morrotes alongados e espigões, e colinas médias e amplas com vales abertos e fechados com presença de lagunas perenes e intermitentes. Nobre (2008) apresenta para a Bacia Hidrográfica do Corumbataí quatro rios principais sendo: o Corumbataí, o principal e os seus tributários os ribeirões Cabeça, Passa-Cinco e Rio Claro.

Segundo Dean (1977), ainda no início do século 19 quase tudo era floresta e cerrado nesta região. Logo, Rodrigues (1999) destaca para a região, cinco tipologias de formações 
florestais: Florestas Estacionais Deciduais e Semideciduais, respectivamente mata de planalto e mata seca; Floresta Paludosa e Ripária, respectivamente mata de brejo e mata ciliar; Cerrado com diversas formações de cerrado strictu sensu, cerradão, campo limpo, campo sujo e campo cerrado. Segundo Valente (2005), em 2003 a cobertura do solo era predominantemente marcada por pastagens (42,29\%), seguido de cana-de-açúcar $(27,77 \%)$, floresta nativa e cerrado $(11,97 \%)$, floresta plantada $(5,69 \%)$, agricultura anual e perene $(4,96 \%)$, área urbana, malha viária, mineração e rede hidrográfica $(7,32 \%)$.

Na porção superior da bacia está sobreposta Área de Proteção Ambiental (APA) do Corumbataí, Botucatu e Tejupá uma Unidade de Conservação instituída pelo Decreto Estadual $n^{0}$ 20960, de 8 de junho de 1983, reconhecida pela Lei Federal $n^{0}$ 9985, de 18 de julho de 2000, que instituiu o Sistema Nacional de Unidades de Conservação da Natureza. De modo geral, este estudo foi realizado somente na porção Corumbataí do mosaico da APA

A APA Corumbataí é uma unidade de conservação de uso sustentável regulamentada pelo Decreto Federal $n^{0}$ 4340, de 22 de agosto de 2002. Por definição APA é "uma área extensa, com certo grau de ocupação humana, destinada a proteger e conservar a qualidade ambiental e os sistemas naturais ali existentes, importante para a qualidade de vida e o bemestar das populações humanas". Dessa forma, a escolha da APA se deu por esta ter legislação própria e ser uma categoria reconhecida pelo SNUC (Lei 9985/00). Além disso, Valente e Vettorazzi (2003), com base no mapa da cobertura do solo produzido para o ano de 2000, citam que as sub-bacias do Passa-Cinco e do Alto-Corumbataí concentram-se as maiores áreas de floresta e os melhores fragmentos nativos da Bacia. Por estes atributos pode ser considerada uma região representativa para toda Bacia Hidrográfica do Corumbataí, já que é são nestas regiões onde se encontra o público investigado neste estudo, bem como, são estás regiões que mais requer atenção em relação à conservação ambiental (Ferraz et al.,2009).

A APA do Corumbataí totaliza 335.205 hectares e as atividades econômicas predominantes são o cultivo de cana-de-açúcar, reflorestamento de eucaliptos e pinus, agricultura, pecuária e mineração de areia, brita e argila. Os atributos ambientais de proteção na APA são as escarpas das cuestas, escarpas do reverso, morros testemunhos e de seu entorno, áreas de afloramento da formação Botucatu-Pirambóia, recursos hídricos superficiais e seu entorno; recursos hídricos subterrâneos, patrimônio arqueológico existente na região, e remanescentes da biota local (SÃO PAULO, 1983). De modo geral, a Bacia do Corumbataí é o universo de inferência do estudo proposto, e o universo amostral é a Área de Proteção Ambiental do Corumbataí - APA Corumbataí (Figura 1). 


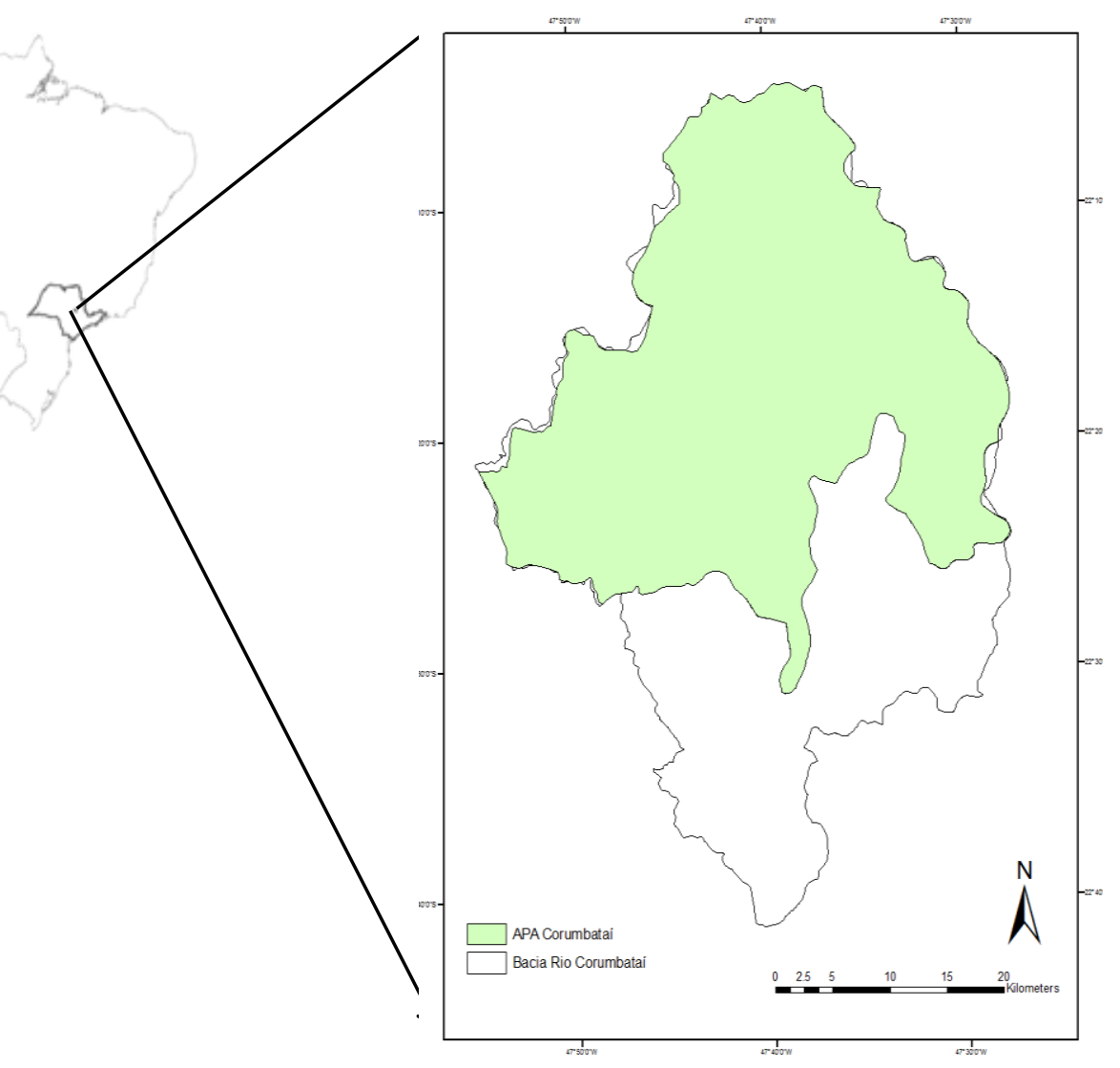

Figura 1- Bacia do Corumbataí, evidenciando a APA do Corumbataí

\subsubsection{Escolha e definição do público alvo}

Devido às diferentes classificações e critérios de "agricultura familiar" adotadas por estruturas ou segmentos econômicos, políticos ou científicos que tratam do tema no Brasil, neste estudo o agricultor familiar foi caracterizado quando a família proprietária dos meios de produção assume os trabalhos no estabelecimento produtivo de até quatro módulos fiscais. Trata-se evidentemente, de uma simplificação, dada as limitações para adoção de uma ou outra classificação feita por diferentes autores ou instituições como: Carmo, (1999), IBGE, (2010), Gonçalves e Souza (2005), Guanzirolli e Cardim (2000) e MDA (2009) que tratam do tema. Para categorizar os módulos fiscais, recorremos aos dados do projeto LUPA 1996/97 e 2007/08 (IEA, 2009) para levantamento das informações referentes às unidades de produção agrícola nos municípios estudados (Tabela 1). 
Tabela 1 - Informações sobre propriedades rurais nos municípios estudados

\begin{tabular}{lrrr}
\hline Município & Módulo fiscal (ha) & Imóveis Rurais & Área Cadastrada (ha) \\
\hline Analândia & 18 & 235 & 30.123 \\
Ipeúna & 16 & 389 & 25.444 \\
Corumbataí & 18 & 669 & 21.074 \\
\hline
\end{tabular}

Segundo Martins (2006), o desenvolvimento rural e a gestão ambiental nos territórios rurais são concebidos como momentos de um mesmo processo, compondo unidade indissolúvel diante das necessidades modernas de geração de renda e uso sustentável dos recursos naturais. Ao optarmos por trabalhar com agricultores familiares que residem na terra, privilegiamos não somente uma das categorias menos desenvolvidas nos padrões modernos da ruralidade brasileira (ABRAMOVAY, 2003), como, legitimou uma categoria “invisível” na região - o caipira. Conforme sugere Candido (2001), sobre as transformações dos meios de vida do caipira paulista (para designar aspectos culturais), as práticas produtivas e formação social também estão articuladas às suas percepções e formas simbólicas sobre o meio ambiente. Segundo Martins (2006), este processo gera uma identidade de percepção e apropriação dos recursos, com acesso e práticas de manejo dos ecossistemas, neste sentido, um conjunto de processos mediadores entre as determinações históricas, políticas e econômicas sobre o uso dos recursos ambientais. Contudo, optamos em trabalhar com este público acreditando que é importante compreender as motivações e os modos de vida destas populações se o objetivo for a conservação ambiental de uma região da Bacia do Corumbataí. Aqui é oportuno fazer uma analogia com o que chamamos na biologia da conservação, de “espécie-guarda-chuva” que são espécies indicadoras que requerem grandes áreas para sua sobrevivência, estas espécies podem ser utilizadas na conservação por trazer muitas outras espécies sobre a mesma proteção (KREBS, 2001). Assim, o "agricultor familiar", termo contemporâneo, ou o "caipira" termo cunhado por Antônio Candido seria neste estudo o “elemento" a ser conservado na Bacia, ou seja, conservar ou manter agricultores familiares no campo pode contribuir para conservação da biodiversidade de modo geral. 


\subsubsection{Coleta de dados}

A escolha dos municípios Ipeúna, Analândia e Corumbataí se deu por estes estarem totalmente inseridos na APA, além de apresentarem fortes relações com o meio agrícola e manterem ainda agricultores com o perfil da agricultura familiar. Como categorização prévia, buscou-se na APA as propriedades de agricultura familiar que tinham relação direta com a rede hidrológica, com os remanescentes florestais, matas ciliares e áreas de preservação permanente (APP), a fim de explorar entre outros assuntos, suas supostas relações com esses elementos da paisagem. Isto foi feito com o auxílio de imagens de satélite e mapas da Bacia hidrográfica (VALENTE, 2001) e, principalmente, com o auxilio das Coordenadorias de Assistência Técnica Integral (CATI) dos municípios envolvidos, que apresentaram uma lista das propriedades com as características desejadas.

Com o auxílio dos técnicos da CATI de cada município estudo, em uma primeira configuração foram identificados 47 agricultores familiares que possuíam as características desejadas. Deste conjunto, a partir dos critérios adotados, privilegiou-se o seguinte perfil: (i) unidade produtiva com até 4 módulos fiscais; (ii) gestão do estabelecimento exercida pelo produtor; (iii) produtor residente na propriedade; e (iv) trabalho familiar superior ao trabalho contratado. É sabido que outras unidades ainda se mantêm produtivas na região, mas devido a sua proximidade com as cidades do entorno, seus proprietários não mais residem no estabelecimento, por esse motivo não foram inseridos na pesquisa. Abramovay (2003) classifica essa situação como condição positiva devido a certas condições virtuosas que permite essa inter-relação entre as cidades e o meio rural. Neste estudo, essa condição virtuosa se distanciava da principal questão perseguida, que trata da relação com o meio ambiente, bem como, conforme exposto acima, que a presença dos agricultores na terra tem a função de elemento-guarda-chuva. Esta colocação está mais próxima das próprias convicções epistemológicas e científicas do investigador.

Para tanto, foi realizada uma pesquisa de natureza qualitativa e quantitativa, de modo a identificar a questão da agricultura familiar e suas relações com a conservação ambiental do ponto de vista da conservação ambiental na Bacia, tendo como foco o contexto dos participantes, suas ideias e sua forma de perceber a realidade sobre o fenômeno pesquisado. $\mathrm{O}$ ponto de partida do levantamento de dados foi a classificação da população, pertinente aos moradores rurais da APA do Corumbataí, com base no tipo de relação que eles mantêm com o uso do terra, considerando-se ainda, questões ambientais, de tal modo, que foi possível estabelecer as relações e percepções com as áreas de preservação permanente os fragmentos 
florestais da região. No trabalho de campo foi útil considerar as abordagens de pesquisa e gestão participativa (BLUMENTHAL; JANNINK, 2000). Tanto com o Diagnóstico Rural Participativo quanto a Pesquisa-Ação Participativa que concentram o foco nas investigações que empoderam as comunidades locais (CHAMBRERS, 1994). Nesse caso, alguns aspectos foram relacionados à origem dos sistemas de produção situados aos níveis ideológicos e simbólicos (DOUGLAS, 1969; SAHLINS, 1976).

Para o levantamento dos dados foram utilizadas técnicas de coleta de dados da abordagem qualitativa, como a observação participante e a entrevista semi-estruturada, a partir de um roteiro previamente definido (ALBUQUERQUE, 2002; AMOROZO, 1996; BERNARDI, 1974; VITTLER, 2006), e de metodologia específica denominada de Análise de Diagnósticos de Sistemas Agrários, disponibilizada pelo convênio Incra/Fao (2010). Além de observação direta ou observação de campo, procedimentos de caráter qualitativo (JACCOUD; MAYER, 2008), e dos preceitos ecológicos do objeto de estudo foram aplicados questionários por meio de entrevistas gravadas para obtenção de relatos orais nas unidades produtivas. Para Viertler (2002) a entrevista é uma das técnicas nas quais ocorre uma relação de comunicação mais equilibrada, entre a visão do pesquisado e a visão do pesquisador. Em relação às observações Viertler (2002), considera indispensável o uso de um diário de campo, onde são anotadas todas as observações, até as impressões subjetivas do pesquisador, relativas a fatos ocorridos na comunidade em que desenvolve o seu trabalho. Impressões subjetivas sobre fenômenos desconhecidos e intuições podem vir a constituir um instrumental precioso para futuros "insights", podendo ou não confirmar previsões baseadas em teorias científicas.

É importante destacar o trabalho de campo foi conduzido com metodologias clássicas das ciências sociais como entrevistas, questionários e utilização de informante-chave, entre outras. E ainda, neste estudo, por pesquisador estar um longo do tempo familiarizado com algumas dessas técnicas, desenvolvemos técnicas particulares para buscar informações a partir diálogos estabelecidos pelo respeito mútuo e de trocas. Nesse sentido a técnica utilizada procurou se adequar aos modos de vida e aos hábitos dos entrevistados, por exemplo, observando, a hora de chegar ao estabelecimento para não atrapalhar a rotina do entrevistado, ser apresentado por um ou mais informantes ou pessoas conhecidas nos órgãos municipais, neste caso, foram os responsáveis pela CATI, além, de saber da pré-disposição do entrevistado em participar do estudo e ceder as informações desejadas. Portanto, a partir destes conhecimentos prévios, de visitas antecipadas nos estabelecimentos e agendamento, iniciamos o trabalho de campo munidos de um questionário semi-estruturado contendo 35 perguntas e pré-elaborado antes de ir a campo (ANEXO B), um roteiro de entrevista (ANEXO 
C) e uma tabela onde eram registradas informações de "presença" e "ausência" das variáreis sócio-ambientais (ANEXO D). De modo geral, o método aqui proposto é misto de registros e levantamentos de dados e análise combinada a partir das entrevistas com os informanteschave.

Logo, as entrevistas versaram sobre a situação da unidade produtiva e dos agricultores, identificando e caracterizando os principais tipos de produtores (pecuária ou agricultura); os principais sistemas de produção adotados; suas práticas sociais e econômicas; a produção e o autoconsumo de alimentos e seus principais problemas. Para obtenção dos dados em relação à renda na propriedade foi estipulado o valor do salário mínimo no país durante o período do trabalho de campo, que era de quinhentos e dez reais. Portanto, para saber a renda mensal gerada na propriedade era perguntado ao entrevistado: “considerando o valor do salário mínimo em quinhentos e dez reais, a sua renda média mensal está entre um e três salários, ou, entre quatro e seis salários?" Por experiência sabemos que é constrangedor falar sobre renda, principalmente com esse público, em face às condições muitas vezes desfavoráveis em que vivem no atual momento do país, ou mesmo à própria simplicidade que é peculiar neste grupo. Por isso, muitas vezes era questionado quanto julgava ser uma renda mensal justa advinda da atividade praticada na terra, a fim de obter um valor próximo daquilo que se tem na realidade.

Buscou-se ainda, utilizando uma tabela com variáveis sócio-ambientais (ANEXO D) identificar as relações dos produtores com o elemento "água na propriedade", bem como, a relação dos produtores com as agências de fomento a conservação ambiental, e os determinantes ou entraves nessa relação. Especificamente, para conhecer o uso e destinação da água na propriedade rural delimitou-se como área de estudo as nascentes, margens dos rios ou córregos próximos ao local da entrevista. Como método de abordagem em relação à qualidade dos recursos hídricos, e levando em consideração a influência das atividades na propriedade, observou-se: utilidade na propriedade (saúde, abastecimento, irrigação, animais domésticos), utilidade para vizinhos à montante, lançamento de dejetos humanos e animais, cultura anual ou perene na APP, APP com ou sem cerca, comprometimento por erosão, mata ciliar presente ou ausente, fragmento florestal nativo presente, reserva legal averbada ou não, e adoção de práticas conservacionistas. A sistematização destes dados na tabela em anexo foi realizada através de presença e ausência das variáveis ambientais, gerando as informações contidas na tabela 5 nos resultados.

A partir das informações coletadas nas entrevistas gravadas e posteriormente transcritas foi construído um quadro de análise (Tabela 2) para expor questões relativas a 
quatro temas relacionados aos proprietários rurais: $\mathrm{a}$ - onde estão; b - quem são; $\mathrm{c}$ - como vivem; e d - relações com conservação da biodiversidade. Com isso buscamos estabelecer o desenvolvimento rural em curso, isto é, as tendências de evolução do pequeno agricultor na região. Contudo buscou-se ainda construir quadros de análises para examinar a situação hídrica nas propriedades e suas supostas relações com outros trabalhos que apontam as principais áreas prioritárias para conservação na Bacia. A partir disso, teve-se como proposta consolidar os dados na tentativa de elaborar um conjunto de indicadores para futuras tomadas de decisões referentes à conservação na região.

Tabela 2 - Tabela exemplo de sistematização e compilação de dados e depoimentos nas entrevistas realizadas com agricultores familiares.

\begin{tabular}{|c|c|}
\hline Entrevista & Nome do entrevistado \\
\hline Coordenadas & 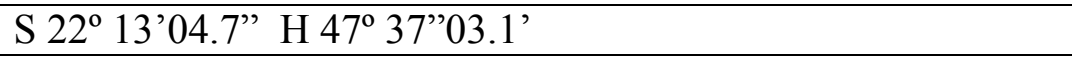 \\
\hline Tipo: & Proprietário \\
\hline Área (alq) & 6 \\
\hline Tempo residência na área. & 45 anos \\
\hline Escolaridade & $1^{\circ} \mathrm{grau}$ \\
\hline Famílias que vivem na área & $\begin{array}{l}3 \text { famílias - um filho trabalha na terra e dois filhos moram na } \\
\text { propriedade trabalham na cidade como eletricista e comércio }\end{array}$ \\
\hline Pessoas na área & 9 \\
\hline Trabalham no sítio & 3 pessoas - entrevistado, mulher, filho \\
\hline Casas & 3 \\
\hline Escolares & 3 netos \\
\hline Renda familiar R\$ & $\begin{array}{l}\text { Aposentadoria, viveiro, destilaria, plantação de legumes e } \\
\text { verduras }\end{array}$ \\
\hline Renda na propriedade & $\begin{array}{l}\text { Média por mês é de } 1000 \text { reais } \\
\text { "com aposentadoria ganho } 510 \text { a mulher } 510 \text {, isso da mil e } \\
\text { cem, mas ela gasta quase tudo com remédio" }\end{array}$ \\
\hline Rio na propriedade & 1, rio Corumbataí \\
\hline Nascente & $\begin{array}{l}\text { 3, mas depois que deixei formar mato ela seca, ela nunca } \\
\text { secava, depois deixei criar mato, mais prejudicou a nascente, } \\
\text { na época das águas elas vertem água, na seca ela seca. }\end{array}$ \\
\hline APP & $\operatorname{sim}$ \\
\hline Água uso & $\begin{array}{l}\text { A água para gasto na casa vem da cidade, para irrigação a água } \\
\text { vem do Corumbataí, tenho um motorzinho com uma } \\
\text { bombinha. }\end{array}$ \\
\hline Mata Ciliar & Sim, lá já foi preservada a margem do rio \\
\hline APP & Sim, eu sei, é os mato na volta da água \\
\hline RL & $\begin{array}{l}\text { Sim, eu não sei se já foi averbada, preciso perguntar pro meu } \\
\text { filho }\end{array}$ \\
\hline Pesca & Não \\
\hline Qualidade do Ric & \\
\hline
\end{tabular}


melhor, pior, não sabe)

água, eu conheço esse rio desde moleque, de pior, ou melhor, eu não sei, antes do rio ser dragado existia muito peixe, muito curumbatá, tinha pra "daná", naquele tempo era tudo alagado as várzeas, plantava arroz do dia 26 e 27 julho na lua nova, até dia 4 a 5 de agosto, se passasse enchia de água, quando madurava o arroz, ai cortava arroz trazia na canoa até aqui pra pode maia. Só perdeu o Corumbataí na parte de criar peixe, porque acabou as lagoas (várzea). Mas pra agricultura melhorou, hoje o trator entre em qualquer lugar, antigamente enchia de água até a estação de trem. A drenagem melhorou para plantio, mas o rio ficou pobre de peixe. Hoje em dia pra mim ele está melhorando porque tão fazendo tratamento de esgoto, sabe o que é, tinhas as empresa e a gente não gosto de citar nome, mas eles soltavam no rio e até o capim ficava preto, empresa grande você já viu, a empresa, com negócio de areia, eles soltavam, hoje não solta mais, porque a fiscalização está em cima, ele tem os tanques de decantação. A agricultura piorou muito, mas o ambiente, já melhorou, tão cercando, a água é importante, a água é a principal coisa na propriedade.

\begin{tabular}{l|l}
\hline Uso atual da terra & Pouco de cana, para o burro e para garapa. Planto quiabo,
\end{tabular} pomar de pera, mandioca, jiló, berinjela, quiabo, pepino, abobora, mandioquinha, moranga, mel, própolis, vinho, pimenta balão, vermelha, gengibre, amendoim, moranga, de época para época agente vai plantando. Tem as verdura tudo, eu sou agricultor que produz.

\begin{tabular}{l|l}
\hline Renda na propriedade. & O mel me dá uns mil reais por ano. As vendas me dão livre
\end{tabular} entre 1000 e 1500 por mês

Renda otimizada por mês $\mathrm{R} \$ 1500,00$

Produção no passado

A gente não tinha nada, foi no tempo do governo militar que nóis subiu. Eu fui o maior produtor de alho de Corumbataí. Eu cheguei a plantar 245 quilos de sementes, eu e meus três filhos trabalhava até meia noite. Eu tive laranja poncã, mas como começou a dar problema de doença eu mandei arrancar tudo. $\mathrm{Eu}$ tive gado, mandava 30-40 litros de leite para Nestlé, comprei um trator e paguei com o pomar de pêra. Plantava arroz, criava bicho de ceda. Plantava um monte de coisa para sobreviver. Ainda hoje é assim.

Mudanças no uso da terra

A exportação de alho á liberada e derruba o preço nosso. Até 83 eu plantava alho, quando saiu o Figueredo, vem alho da argentina, china. $\mathrm{O}$ Galdino aguentou plantando alho por que ele tem um terreno plano e grande, e ele tem capim jaraguá que não entrou braquiária. Se nós fossemos planta alho nem se quisesse não podia por que não existe mais capim rabo de boi e Jaraguá, porque a gente plantava tudo forrado com capim, empalhado, tudo forrado, "nos puxava capim até meio noite eu e os filhos". Naquela época compensava, porque começava a plantar o alho no preço e eu tinha um barracão e segurava o alho e vendia quando não tinha. $O$ governo segura a importação, quando estava no final da safra do alho o governo liberava a importação, mas só no final da safra, ai 
compensava. Agora não, agora é direto, não tem fronteira, vem vindo alho da china de tudo lugar e tá complicando pra nós que produzia, falta uma política agrícola, mas o preço também não é bom, por isso não é bom plantar. $\mathrm{Na}$ época que nós plantava, só pra fazer uma comparação, com $1 \mathrm{~kg}$ de alho, nós comprava 20 litros de gasolina, isso na época de 70 até 75 . Hoje o cara ali na roça, o vizinho, não consegui vender a 2,50 o kg, isso depois de seco, tentou vender a 4 reais com o talo cortado, a uns dois anos ele vendeu a 1,50, alho bonito. Já pensou se compensa plantar um produto desses.

A gente produz muita coisa, mas tem coisa também que a gente foi parando de produzir, repolho, couve-flor, brócolis, não plantamos mais por causa da traquinose (doença) e por causa do preço, pois esses produtos vão dar preço, na época que a gente não pode produzir, por causa da chuva e tal, porque dependendo da região tem produto que não adianta você plantar porque perde tudo. Aqui por exemplo, nem abóbora na época da chuva a gente não pode plantar. $\mathrm{O}$ ano passado e esse começo de ano pra nós foi PÉSSIMO. O preço da caixa de abóbora (abobrinha eu vendi a 15 e 18 reais), mas a abobora de doce foi 0,50 centavos o quilo. Aqui eu falo é uma propriedade de subsistência, porque você vê, só na horta que tem as plantas pro gasto tenho, cheiro-verde, tem uma couve pro gasto, você cria um porquinho, então você tem aqui uma agricultura familiar mesmo. Hoje o pequeno produtor é subsistência, você pode ver com qualquer outro produtor, ao menos que ele tiver fonte de renda de outra coisa, aposentadoria alta, ou outros negócios, mas hoje a agricultura familiar é subsistência. Ninguém mais ganha dinheiro para fazer império, isso pode esquecer. Filho (João) eu não consigo hoje, juntar o que meu pai consegue. Se a agricultura continuar como está, não é a intenção, mas ce lubrifica, engraxa todas máquinas e larga ai em baixo do barracão e vai trabalhar para fora, mas se um dia precisar plantar pra sobreviver da terra nós tem. Terra pra subsistência nós tem, mas pra ganhar dinheiro não. Depois que comprou essa terra aqui, a varge (várzea) aqui nós enchia de arroz, e ganhei dinheiro com arroz, mas foi indo, foi indo, precisei deixar, cai fora, não dava nada, não sobrevivia, então agente foi mudando. Hoje eu não planto arroz nem pro gasto, veja bem, um saco de arroz em casca, custa 27 reais o saco de sessenta quilos, isso é uma piada, um saco de trigo 22,50 , o feijão estava 59,0 o preto que é mais caro. Com esses preços o agricultor não paga o serviço, plantar essas coisas é bom pro grande, por que ele debate no IR, o pequeno paga o empréstimo, o grande não paga, para pequeno agricultor ficou péssimo, se ele não tiver uma estrutura, eu estou aqui por que gosto, tenho reserva, tenho estrutura, quer dizer se eu quero produzir, eu tenho, não preciso emprestar dinheiro em banco, então se o agricultor não for econômico pode esquecer, ele vai pro buraco mesmo, tem que arrendar 
mesmo. Então você tem que produzir naquilo de da um pouco de lucro e que você investe menos. Por exemplo, a gente agora tá entrando na mandioca, primeiro porque a gente tem terra boa, faz uma cobertura barata de 25/20 quando ela tá com um palmo um palmo e meio, então ela sai, e você não gasta em agrotóxico, quer dizer não polui a natureza e ela é uma fonte, que tem que trabalhar, mas hoje é o que tá me dando dinheiro, pra sobreviver é claro, ficar rico não fica mais. A gente planta, pepino, abobrinha, quiabo, o quiabo é o mais forte nosso hoje, por que também não usa agrotóxico, por tanto, ninguém pode com nós lá em São Carlos por causa disso, a turma já conhece, faz trinta anos que vendo em São Carlos e é tudo padronizado. Eu tenho um meeiro, é um senhor de 78 anos, que planta aqui, aquele amendoim é dele, eu aro a terra, preparo a terra, risco, e se precisar regar eu rego também, isso é a quarta, mas porque eu tô dando uma mão pra ele, embora eu tenha que investir, aquele dinheirinho vem e ainda ajudo uma pessoa que merece, porque é trabalhador

\begin{tabular}{|c|c|}
\hline Implementos & $\begin{array}{l}\text { Trator, grade, arado, roçadeira, rotativa, pulverizador. } \\
\text { Carpideira a burro. Destilaria. }\end{array}$ \\
\hline Destino da produção & $\begin{array}{l}\text { São Carlos - horta, vinho, licor, mel, própolis eu vendo aqui, } \\
\text { tenho } 20 \text { caixa de mel silvestre la no meio do mato. Mel é um } \\
\text { bico, me dá mil reais por ano. }\end{array}$ \\
\hline Quintal & Tem de tudo \\
\hline Alimentação & $\begin{array}{l}\text { Compro tudo em São Carlos, sal, óleo, arroz, batata, cebola, } \\
\text { carne, salame mortadela, parmesão (Scalla) }\end{array}$ \\
\hline Gasto com comida & Mais ou menos 400 reais \\
\hline Come bem em casa & Como variedade \\
\hline Boa alimentação é: & $\begin{array}{l}\text { Verdura e legumes, com exceção da carne de porco, carne de } \\
\text { vaca se não existisse não precisava, nós fomos criados com } \\
\text { carne de porco, hoje como azeite. }\end{array}$ \\
\hline Não pode faltar em casa: & Essas coisas \\
\hline Alimentação no tempo & Igual hoje tem mais fartura nos mercado \\
\hline Transgênicos & $\begin{array}{l}\text { Eles cria um produto menos perseguido a doença, na minha } \\
\text { opinião é boa coisa, eu não acredito mais em agrotóxico, } \\
\text { porque eles diminuíram o poder ativo, você esta gastando } \\
\text { dinheiro e não esta combatendo a doença. Então o que eu } \\
\text { trabalho aqui é diversifico a plantação e olho a lua, três dias } \\
\text { antes de fazer cheia, se planta, ai já esta nascendo, e na cheia } \\
(59 \text { ") esta crescendo. Abobrinha pepino melão tudo que é } \\
\text { rasteiro, três dias ante de lua se fazer cheia, você planta ela } \\
\text { germina e nasce na minguante, dificilmente dar doença e } \\
\text { lagarta no pepino e na abobrinha, e outra, não repetir planta, } \\
\text { diversifica, rotação de cultura, então você usa o mínimo de } \\
\text { agrotóxico, então na abobrinha, nos usa o furadam, mas são } 90 \\
\text { dias, né? Então o quiabo por exemplo, a única vez que é } \\
\text { obrigado pulverizar é por causa do pulgão. Pro milho eu fazia } \\
\text { o mesmo serviço, ele nasce na minguante, com pé baixo e } \\
\text { força na espiga, a arroz planta na crescente, se não dá cacho } \\
\text { pequeno. Eu plantaria transgênico, mas o que eu ouço dizer é }\end{array}$ \\
\hline
\end{tabular}




\begin{tabular}{|c|c|}
\hline & que é uma planta mais resistente à doença. \\
\hline Produtos na prop. & Ver acima \\
\hline Mão de obra familiar & $\operatorname{sim}$ \\
\hline Diversidade agrícola & alta \\
\hline Auto-consumo & alto \\
\hline Tração animal & Sim, \\
\hline Agr. Org/agroecologica & $\begin{array}{l}\text { Não, usa agrotóxico, tudo dosado, nos usa o furadam, só na } \\
\text { abobrinha, no pepino eu não ponho de jeito nenhum, por que } \\
\text { no pepino fica com gosto de veneno dentro, o pepino daqui } \\
\text { que eu planto não. }\end{array}$ \\
\hline Insumos químicos & suficientes \\
\hline Insumos biológicos & Sim, esterco de curral \\
\hline Fragmento floresta & Sim \\
\hline Pratica conservacionista & Não \\
\hline Erosão & Não \\
\hline Vegetação nativa APP & Sim, a jusante $\mathrm{Tb}$, a montante, não \\
\hline Exótica APP & Não, \\
\hline Cercada & Não, pq não tem gado \\
\hline Capitalizada & Sim \\
\hline Crédito banco & $\begin{array}{l}\text { Não faço, tem que renovar contrato e ai tem que pagar } 300 \\
\text { conto pro banco, se investir na compra de um trator para } \\
\text { agricultura não dá para pagar, a não ser que tem um outro } \\
\text { lucro, de gado, se não pode esquecer }\end{array}$ \\
\hline APA - PSA - PCJ & não \\
\hline
\end{tabular}

Portanto foram a partir dos quadros sistematizados para cada entrevista, conforme vimos anteriormente que se estabeleceu a metodologia analítica. Assim, as questões pertinentes aos dados "socioeconômico-ambientais", as análises referentes ao universo pesquisado foram feitas das seguintes formas: 1- os dados foram trabalhados de forma interpretativa com categorias construídas a posteriori, de acordo como preconiza Geertz (2000); 2- os relatos orais dos entrevistados na APA do Corumbataí foram comparados entre si, dentro das categorias definidas; 3 - sobre a agricultura familiar e meio ambiente, a noção de multifuncionalidade ambiental foi utilizada como instrumento de análise; e 4 - os relatos orais presentes no texto indicam o posicionamento do informante quando da coleta dos dados/relatos. Deste modo, a citações orais são apresentadas no texto, de modo que as falas explicitem as relações e os conflitos acerca das questões sociais, econômicas e ambientais dos informantes, no entanto, não se traduz como uma etnografia.

Para discussão sobre a agricultura familiar fizemos uso dos trabalhos de Hugues Lamarche (1993, 1998), respectivamente sob os títulos "Agricultura Familiar: uma realidade multiforme" e "Agricultura Familiar: do mito à realidade". Estes estudos oferecem uma abrangente e profunda colaboração acerca da agricultura familiar no mundo contemporâneo e 
suas múltiplas facetas, passando a ideia precisa sobre a agricultura familiar e sua diversidade. Para situar o leitor, os trabalhos referência foram realizados no Canadá, França, Tunísia, Polônia e Brasil.

Para anuência e uso das informações advindas da pesquisa, este estudo foi submetido e aprovado em junho de 2010 pelo Comitê de Ética e Pesquisa da ESALQ/USP, e a partir disso foi apresentado aos entrevistados o Termo de Consentimento Livre e Esclarecido, obtendo assim licença para uso dos dados no presente estudo. A pesquisa aqui apresentada foi realizada a partir das entrevistas e observações desenvolvidas em campo durante o ano de 2010, cujos dados principais foram sistematizados e analisados em 2011.

\subsubsection{Resultados}

\subsubsection{Agricultura familiar na APA}

As unidades produtivas ou imóveis rurais cadastrados nos municípios estudados estão mostrados na Tabela 3. Todavia, não foi possível verificar o número de imóveis inseridos apenas nos domínios da APA. A população ocupada na agricultura no Estado de São Paulo reside majoritariamente em áreas urbanas, tanto na agricultura patronal quanto na agricultura familiar (FRANÇA et al., 2009). Isso pode ser observado na APA pela dificuldade de encontrar unidades produtivas habitadas que, de modo geral, estão abandonadas ou englobam grandes extensões de pastagem ou cana-de-açúcar, pertencendo a um mesmo proprietário com matrículas de muitos imóveis. Apesar de ter um considerado número de unidades produtivas na região, a densidade demográfica na área estudada é relativamente baixa.

Tabela 3 - Unidades produtivas por município estudado (*Imóveis rurais cadastrados no Sistema Nacional de Cadastro Rural - Índices Básicos 2005 - INCRA - Base de Abril 2007, ** População Rural nos Municípios Estudados (Fonte: FUNDAÇÃO SEADE, 2010)

\begin{tabular}{|c|c|c|c|c|c|}
\hline \multirow[t]{2}{*}{ Município } & \multirow[t]{2}{*}{ Imóveis Rurais* } & \multicolumn{2}{|c|}{ Agr. familiar } & \multirow[t]{2}{*}{ População Rural*** } & \multirow[t]{2}{*}{ Entrevistas } \\
\hline & & Unidades & ha & & \\
\hline Analândia & 235 & 51 & 1.342 & 888 & 03 \\
\hline Ipeúna & 389 & 127 & 2.271 & 838 & 10 \\
\hline Corumbataí & 669 & 212 & 4.334 & 1.781 & 20 \\
\hline Total & 1.293 & 380 & 6.947 & 2.507 & 33 \\
\hline
\end{tabular}

Nos últimos anos, os responsáveis pelo êxodo rural nesses municípios foram: a expansão canavieira, a especulação imobiliária, o baixo incentivo para agricultura familiar, a 
falta de apoio técnico e financeiro, e de políticas de manutenção do homem no campo. Segundo os moradores, os baixos preços da terra contribuíram para o abandono no campo, e comentam:

O grande proprietário acabou com o pequeno, aqui nessa região tinha uns 'cinqüenta pequeno' que nem eu, hoje tem 3 ou 4, o resto vendeu tudo o sítio, parou tudo, uns abandonaram outros venderam....um cara de fora comprou um monte de sitinho aqui e tem um terrão agora. (N.N.)

Eu que sempre trabalhei, sempre criei, não quero vender, mas a situação tá bem difícil pra nós. Tem muitos por ai que venderam a terra ou arrendaram, uns compraram uma, duas casinhas na cidade e tem um aluguel. O preço pro pequeno produtor é caro. (J.B.)

Como a amostra selecionada abrangeu somente agricultores familiares residentes na APA, o quadro geral é preocupante, tendo em vista que foram encontradas apenas 33 unidades produtivas das 47 iniciais, sendo dez famílias no município de Ipeúna, vinte em Corumbataí e somente três em Analândia. Acreditamos que este número representa quase a totalidade das propriedades que atendem as premissas exigidas para definição do público alvo. Os dados referentes ao universo pesquisado perfazem um total de 33 entrevistas com 11 horas gravadas, transcritas na íntegra e sistematizadas com os depoimentos coletados na pesquisa de campo. A área total amostrada foi de 1.107,46 hectares, que correspondem 0,33\% do território da APA (335.205 ha) (Figura 2). Os resultados das entrevistas apresentados a seguir são a base para caracterização socioeconômica e ambiental e discussão posterior. 


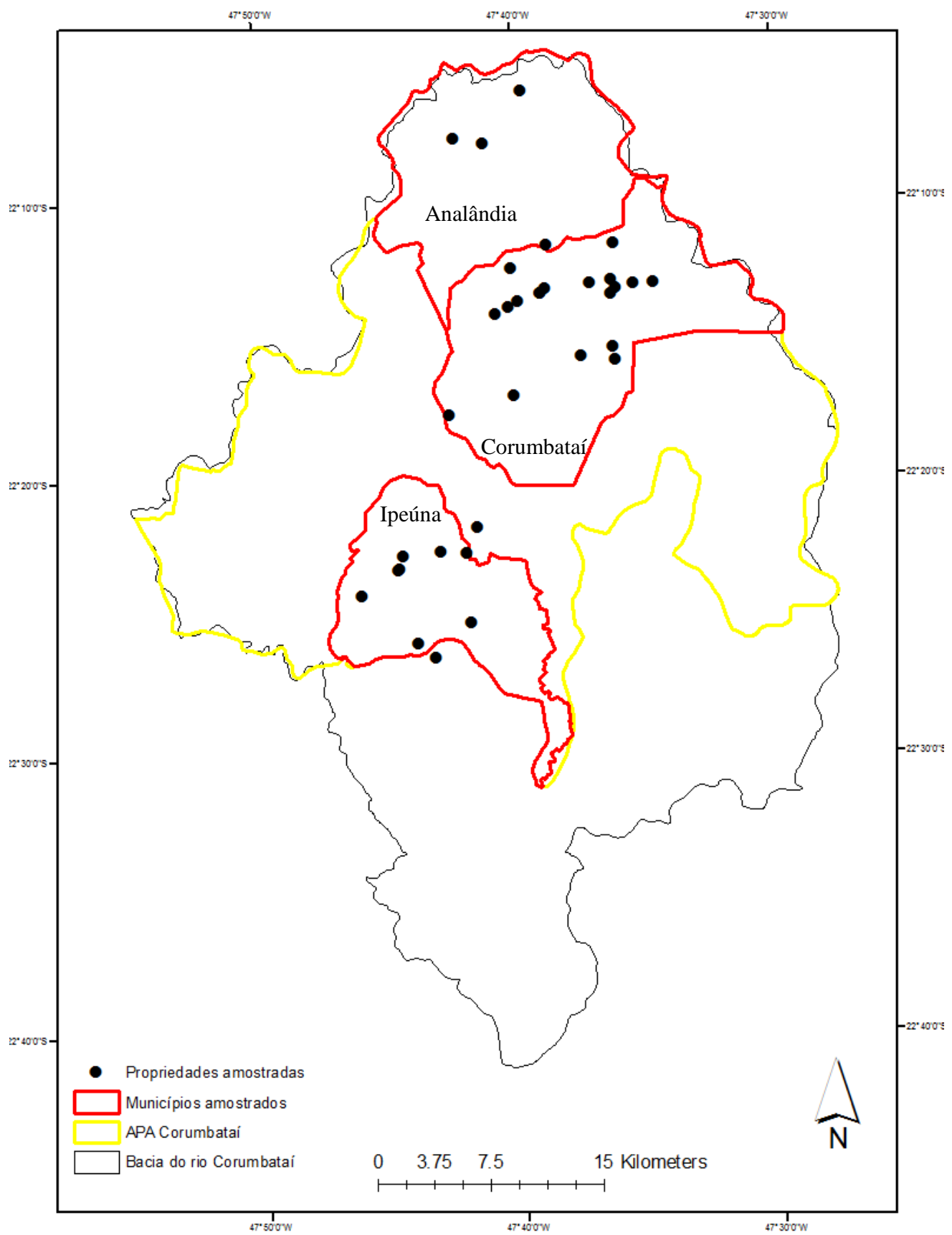

Figura 2 - Unidades produtivas da Agricultura Familiar visitadas na APA Corumbataí

\subsubsection{Caracterização sócio-econômica}

Nas 33 unidades produtivas visitadas residem 49 famílias com uma população de 151 pessoas, das quais 74 estão envolvidas diretamente com atividades agrícolas. A população acima de sessenta anos, representa quase metade dos produtores rurais entrevistados e todos contam com o benefício da aposentadoria. Apenas quatro entrevistados estão nas unidades 
produtivas há mais de 5 e menos de 15 anos, o restante está há mais de trinta e cinco anos. Isso sugere uma importância na história de vida e relação intima com a região. Segundo Dean (1977), já nos primeiros anos de uso e ocupação intensa na Bacia, muitas famílias de imigrantes se fixaram na região após a crise do café em 1929, e ainda hoje encontramos e entrevistamos descendentes de poloneses, alemães e italianos, que residem nas mesmas propriedades desses primeiros imigrantes. Entre os entrevistados, a metade tem a unidade produtiva como fonte exclusiva de renda, o restante detém características da pluriatividade ou, apesar de residirem na unidade produtiva, obtém rendas advindas de outras fontes, por exemplo, aluguel de imóveis nas cidades. As unidades produtivas possuem entre dois e 52 alqueires, medida padrão usada regionalmente ( 1 alqueire $=2,42$ hectares). No entanto as análises consideram seus respectivos hectares, medida oficial referente aos módulos fiscais, estando às unidades produtivas entre quatro e 72 hectares (Figura 3).

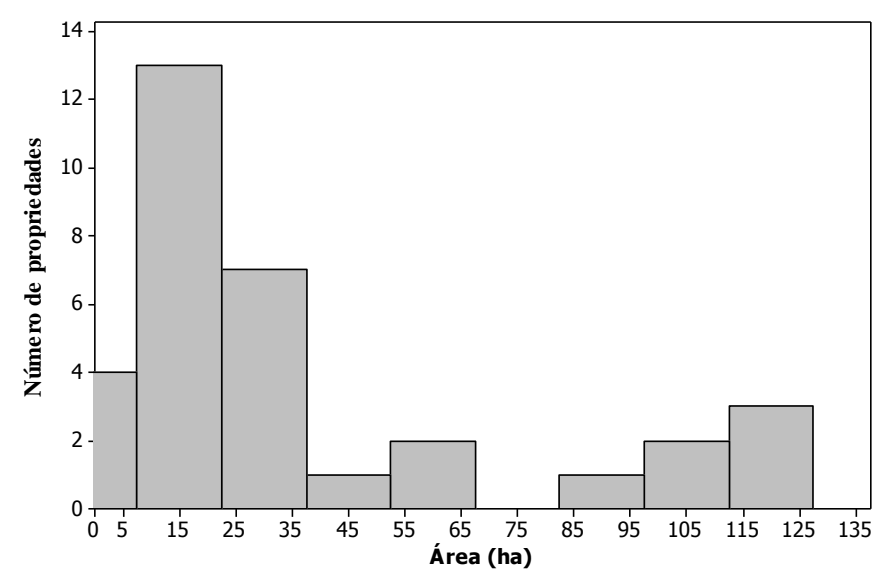

Figura 3 - Distribuição das propriedades visitadas em função da área

$\mathrm{Na}$ amostra selecionada aparecem seis unidades produtivas acima de setenta e dois hectares, o que as descaracterizaria como unidades produtivas preconizadas na qualidade de agricultura familiar. No entanto, estes fizeram parte da amostra por atenderem a outros requisitos como, residirem na propriedade, não terem mão-de-obra contratada e se identificarem como agricultores familiares. De certa forma, a presença destes não enviesa o resultado, ao contrário, colabora, por eles apresentarem semelhanças com aqueles com menos terra que residem na APA. Para verificar as características econômicas da unidade produtiva e do próprio agricultor as seguintes correlações foram realizadas: renda $\mathrm{x}$ área e área $\mathrm{x}$ renda $\mathrm{x}$ tipo de uso da terra (Figura 4). 
a

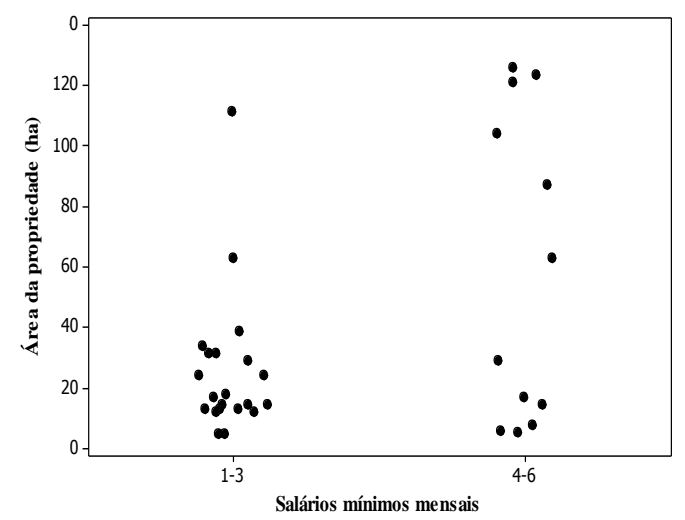

b

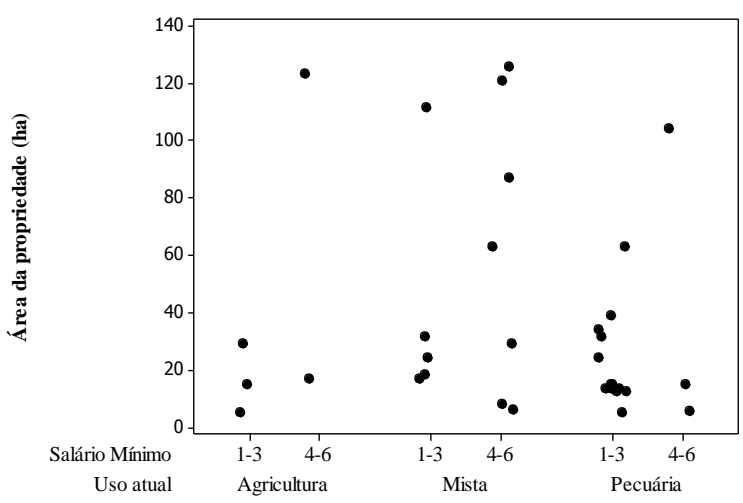

Figura 4 - Relação entre área e renda em salários mínimos mensais (a) e entre área, renda e tipo de uso da terra (b)

As figuras a e b acima oferecem dados que vão exatamente na direção do que é consagrado na literatura nacional e internacional sobre o tema agricultura familiar onde, em unidades produtivas menores (neste caso menores que 40 hectares) a formação da renda é pequena, embora há aqueles com mais terra e pouca renda e também aqueles com pouca terra e maior renda. O uso da terra foi dividido em três grupos: 1 - Agricultura, unidade produtivas voltadas apenas para produção vegetal, 2 - Mista, unidades produtivas com produção vegetal e animal (gado de leite, gado de corte, granja, ovinos); e 3 - Pecuária, onde as unidades têm como atividade principal a bovinocultura com gado para leite e corte, e avicultura no sistema tradicional ou no sistema integrado de granjas. Nos três grupos descritos encontramos diferentes combinações quanto ao uso da terra, aos meios de produção e à força de trabalho, confirmando, a diversidade das lógicas produtivas da exploração exclusivamente familiar.

No grupo dos que se dedicam à pecuária, tanto para leite quanto para corte, as técnicas utilizadas são rudimentares, as pastagens são consideradas "fracas" e sua produção destinada ao mercado local, gerando o suficiente para cobrir as despesas. Há, no entanto, diferenças daqueles que estão voltados para a criação de aves nos sistema de granja, que aparentemente obtém maiores benefícios devido à especialização e aos contratos com empresas ou cooperativas. Já no grupo misto, a produção animal e vegetal é diversificada e destinada tanto para o comércio quanto para o autoconsumo. No grupo misto estão doze produtores entre os quais estão aqueles que se aproximam das práticas mais modernas de agricultura, no sentido da sustentabilidade e permanência no campo. 
Existem diferenças significativas entre o tamanho da área e a renda, mas isso parece não ser regra, já que existem entre as unidades produtivas menores com renda superior àquelas com maior quantidade de terra. Nesse caso, em relação à renda, a pluriatividade e as rendas não agrícolas das famílias rurais aparecem como estratégias para viabilizar sua permanência no campo. O tipo de atividade não agrícola presente nas unidades visitadas é exercida na cidade e localidades próximas e não fizeram parte deste diagnóstico. Portanto, verificou-se somente a dinâmica socioeconômica nas unidades produtivas que estão diretamente relacionadas à área de estudo.

Observamos que algumas famílias estudadas apresentam alta heterogeneidade na forma com que exploram a propriedade, indicando que a área da propriedade não influencia diretamente nos modos de produção e nas estratégias para obtenção de renda familiar, mas sim que é a força de trabalho, o acesso a crédito ou ainda os desejos de permanecera na terra. Em alguns casos percebe-se que a forma de uso e aproveitamento da terra faz com que alguns produtores se diferenciem da maioria. Foi possível verificar que os sistemas de produção mista mostraram-se mais vantajosos em relação aos outros mais específicos. Os depoimentos a seguir são de proprietários classificados com atividades mistas:

\footnotetext{
Aqui tem eucalipto, pasto, milho, café 80000 pés, granja 140 mil frango sem integração, minha granja é particular, esse negócio de integração é ilusão, você vira escravo da granja e o preço nunca é garantido. (J.A)

Produzo porco, tenho três porcas de cria, da dez por cria, são trinta porcos, vendo uma parte e seguro uma parte para comer, esses porquinhos vai chegando o que vai sobrando eu vou vendendo... frango eu crio uma média de 80 frangos... agora eu plantei 200 limões, 200 laranja charmut, 200 pocã, 200 pera-rio, pros mercado... plantei maracujá e levei uma cabeçada, perdi uns 30000, deu trabalho pra repor... eu plantei há uns anos um pouco de eucalipto e arrendei uma parte pra cana... em um alqueire de mandioca bem formado da quase umas mil caixa, vendendo a 10 reais da mais que a cana, e mandioca não dá trabalho, o trabalho que dá e arrancar, vai pouco adubo, não vai veneno. Planto feijão pro gasto. (J.D)

Tenho leite e granja integrada, a mais moderna, investi cerca de 200 mil reais, pra pagar em 6 anos, mas ela se paga, mas a energia, os gastos, mais o serviço da gente, se for calcular ai não... hoje a granja trabalha para firma, depois que ela for paga ai começa a pagar o meu dia, porque esse não dá pra colocar hoje, ai já fica meio complicado... minha granja é pra 20000 frangos...tiro leite, 300 litros dia... quem cuida do leite é o genro e mais um funcionário... mas se eu vendesse o gado e arrendasse a terra pra cana, daria mais que o leite, porque o leite da muita despesa, e tá sempre no vermelho, tem um pouco de eucalipto pra serventia. (J.J.M)
}

Já as unidades produtivas que estão envolvidas tão somente com a pecuária bovina obtêm os menores rendimentos: 
...eles pagam quarenta e dois centavos o litro, independente da qualidade, é o preço dele mesmo, se eu quiser eles pagam isso, se não eu não preciso nem entregar....nesse preço eu empato, por que lucro você não vê, a minha renda com leite por mês é em torno de mil reais....o leite foi bom até os dois primeiros anos do plano real. (F.A)

...tiro de 60 a 100 litros por dia depende o mês, hoje eu tô recebendo 0,48 centavos, mês passado recebi 0,55 o litro, e preço é ruim, o mínimo deveria ser uns 0,90 pra valer a pena...tenho um gadinho de corte mas tá pior mexer...se eu tiver como sobreviver aqui eu fico aqui. (F.S)

Eu tenho 50 cabeças de gado e vivo do gadinho, do queijinho, tiro leite, 25 litros, frango, ovo...vendo um bezerro, vaca véia. Eu tenho pasto nativo, milho, cana, eu nunca tive orientação de ninguém, a gente não tem força para nada, vai vivendo para não dever pro outros. (J.R.S)

Hoje eu tenho 20 vaca, antes eu tirava 200 litros de leite, mas a ração é caro, remédio é caro, e o preço do leite não dava pra custear. Agora eu diminuí e tiro leite e vendo na cidade...eu tiro hoje 70 litros e eu vendo a 1 real o litro. O caminhão paga 0,60 ou 0,45 (centavos) depende da época do ano, na seca paga melhor, mas tem que dar trato pra manter...meu gado é jérsei, da menos leite e come menos....Eu fiz curso de fazer queijo mas não dá pra fazer, você gasta uns 10/12 litro de leite para fazer um queijo de $1 \mathrm{~kg}$...ai vai ter que vender pro 12 reais, ai 'oce' num acha quem compra. Eu tenho intenção de empacotar leite no futuro. (M.S)

Tiro leite, 300 litros/dia quem cuida do leite é o meu genro e mais um funcionário temporário...mas se eu vendesse o gado e arrendasse a terra pra cana, daria mais que o leite, porque o leite da muita despesa, e tá sempre no vermelho. (J.J.M)

Há também os que na pecuária tem como atividade principal a criação de aves (granjeiros) e estes aparecem entre os com renda superior, e nos trazem as seguintes colocações:

Granja, eu crio frango integrado com uma firma de São Paulo...16 mil aves de corte...a firma da ração pintinho, medicamento, veterinário, eu entro com granja, água, energia e meu trabalho, para cada tantos quilos de ração ele paga tanto quilos de frango, eu vendo a cama de frango para um que me traz a serragem. (D.A.B)

Eu não sei direito eu tiro 18000/20000 mil a cada setenta dias...eu tenho a granja financiada, esse mês eu tenho que pagar 16000 mil pro banco, e o frango desse mês não vai dar por que perdi muito, por mês eu não sei direito, faz cinco anos que eu pago o financiamento, ano que vem eu termino, mas eu vou fazer outro financiamento pra incrementar a granja. (C.C.B)

Entre as unidades produtivas voltadas exclusivamente para agricultura temos situações distintas entre os agricultores. As declarações a seguir são respectivamente de um produtor com pouca terra e a de um produtor tecnificado:

...tenho 3000 pés de uva 'niagara', ano passado eu produzi 400 caixa de uva, era pra produzir mais, mas o sanhaço é uma praga, essas uvas me deram de lucro no ano passado cerca de 2400 reais...nessa região só eu produzo uva, eu queria plantar mais uns 10000 pés mas não tenho recurso, fica caro produzir, morrão, arame, muda, mão de obra...a casa da agricultura não ajuda nós em nada. (J.P.L)

...sou tecnificado pra milho, tenho maquinário, então eu planto milho...o milho é minha maior produção eu colho umas 130 tonelada por ano em 9 alqueires...gasto 
mil reais de adubo, 350 de milho transgênico...é um milho de boa produção e não tem gasto com a lagarta, a lagarta não corta ele, não come ele, e eu também não como, se nem a lagarta come, eu é que não vou comer, para comer eu planto o convencional (grifo nosso). (J.B)

A partir do grifo destacamos mais duas falas a respeito do milho geneticamente modificado, utilizado pelos agricultores familiares na Bacia do Corumbataí:

Eu tenho medo, pode ser uma coisa modificada que as vez não vai dar certo na saúde da gente...eu não como esse milho, pra nós, pra pamonha é um quadro separado...as espigas são igual, dá impressão que a produção dele é maior, é igual não muda nada...não sei por que motivo você anda no meio dele e dá coceira, o que tem nele...tipo alergia, a gente é acostumado andar no milharal, a gente estranhou nessa parte, não sei o que é, parece que tem um pó nele diferente, ai coça.

como é que você vai fornecer uma tecnologia caríssima para um produtor como eu, ninguém vai fornecer um tecnologia tão cara a troco de nada...eu não sou refém da Monsanto, sou um cobaia dela, porque nós não sabe o que tá nesse milho...daqui uns quatro, cinco anos o que vamos ter que comprar dela pra por nesse milho, tem alguma coisa por trás, ah tem... ele é amargo, se você pegar a espiga de milho verde transgênico e morder e depois morde o milho comum você vai perceber que o transgênico é amargo, o comum é doce.

Apesar dos rendimentos serem maiores naquelas unidades que possuem mais terra, em grande parte das unidades produtivas visitadas (25) o tamanho está entre 4 a 37 hectares e, embora pareçam existir as mesmas dificuldades, algumas famílias, mesmo com pouca terra, conseguem obter rendas superiores a quatro salários mínimos:

Eu tenho aqui pastagem, fruticultura e olericultura, planto alho, maracujá, abóbora...eu e meu irmão colhemos 7 mil quilos de alho, no ano passado deu zebra, choveu muito, e joguei bastante fora. O maracujá nós começamos porque a gente já sabia que tinha comércio, tem um pessoal que vende pra indústria, mas ai cadastramos no PPA (restaurante popular) em São Carlos, ai começamos vender para eles e nos mercados de lá, estamos encaixando tudo no mercado. (C. D. G)

Um cara ai, vem toda quinta-feira buscar mandioca e leva dez 'caixa' de mandioca à 10 real, são 400 por mês, não é nada, mas é 400 reais por mês. Se eu não entro com um pouco de café, um pouco de laranja, um pouco de limão, eu já tinha ido embora também. Tem mês que não tem dinheiro, mas eu produzo e vou vivendo. Na época da melancia eu planto melancia, planto, vagem, nas beirada de cerca eu planto quiabo, vendo pro mercado (J. D.)

A gente produz muita coisa, mas tem coisa também que a gente foi parando de produzir, repolho, couve-flor, brócolis, não planta mais por causa da traquinose (doença) e por causa do preço. O ano passado e esse começo de ano pra 'nóis' foi péssimo. O preço da caixa de abóbora (abobrinha eu vendi a 15 e 18 reais), mas a abobora de doce foi 0,50 centavos o quilo. A gente planta, pepino, abobrinha, quiabo, o quiabo é o mais forte nosso hoje, por que também não usa agrotóxico, por tanto, ninguém pode com 'nóis'... faz trinta anos que vendo em São Carlos e é tudo padronizado. (G.C.)

Milho e laranja, gado, tenho umas vinte cabeça e faço queijo, vendo na cidade, o caminhão não vêm buscar o leite aqui, eles não tem interesse, então eu faço 
queijo....mas não da lucro nenhum, só prejuízo, eu tiro uns 120 litros por dia, e vendo pro laticínio por 60 centavos esse mês, mês passado pagaram 50 centavos, depende da época do ano...O milho é minha maior produção eu colho umas 130 toneladas por ano em 9 alqueires, e o resto é pasto e cana pro gado. (N.N)

Nas entrevistas e depoimentos coletados, ouviu-se que o processo de especialização ou diversificação tem início já a partir da década de 1990 com o crescimento da cultura canavieira. Neste estudo, quatro entrevistados arrendam suas terras para esse tipo de produção, entre estes estão dois da categoria agricultura e dois da categoria mista, que relatam:

\begin{abstract}
Arrendei uma parte pra cana...arrendei por mês, 940 reais por mês, arrendei uns 17 alqueires, faz cinco anos que eles me 'paga' sempre essa média, eu acho péssimo, por que em 17 'alqueire' tem que produzir mais, se eu plantar café ou outra cultura eu ganho mais. Em dois/três alqueires de terra que eu tenho café vai dar quase o mesmo valor da cana num ano...a conta que eu faço é essa.. eu não vejo hora de acabar com esse contrato. (J.D)
\end{abstract}

Eu arrendo faz três anos, eu vendo 700 toneladas por ano, essa conta varia por causa do preço da cana, no ano passado eu recebi 28 mil reais, da uma média de 2.300 reais por mês, mas esse ano vai dar menos. (J.A)

...tenho 7,5 alqueire plano, mas a proposta é de pagar 30 tonelada por alqueire, e é muito pouco, da quase mil reais por alqueire por ano...no final vai dar oito mil reais por ano, e não tem outra coisa que da mais que isso, então é melhor arrendar do que não produzir nada. (A.S)

Arrendo pra cana já tem seis anos, por que esse é um dinheiro sagrado, chega no fim do ano ou do mês recebe, aqui é anual...esse ano eu vou receber uns 50 mil. Hoje eles pagam 35 tonelada por alqueire, eu arrendo 40 alqueire, eles chegam colher mais de duzentas a trezentas tonelada por alqueire. A usina deixo os trinta metros em tudo beira de água eu perco quase 15 alqueire só de mato nas beira de rio, mas não tem mato, só tem a faixa no lado dos rios. Hoje é cana, eu tiro um pouquinho de leite 40/50 litros, mas não da nada. Mas arrendar para cana foi boa coisa, eu ainda tenho arrendado até 2012. (A.B)

Alguns relatos apontam que no passado produziu-se muito alho na região, no entanto, encontramos apenas três produtores desta atividade, um na ainda na atividade e dois que já deixaram de produzir:

Eu fui o maior produtor de alho de Corumbataí. Eu cheguei a plantar 245 quilos de sementes, eu e meus três filhos trabalhava até meia noite...até 83 eu plantava alho...só pra fazer uma comparação, com $1 \mathrm{~kg}$ de alho, nós comprava 20 litros de gasolina, isso na época de 70 até 75 . Hoje o cara ali na roça não consegui vender a 2,50 o kg...já pensou se compensa plantar um produto desses... a exportação de alho tá liberada e derruba o preço nosso. (G.C)

o 'Galdino' aguentou plantando alho por que ele tem um terreno plano e grande, e ele tem capim 'jaraguaia' que não entrou 'braquiária'...se nós fossemos planta alho nem se quisesse não podia porque não existe mais capim 'Rabo-de-boi' e 
'Jaraguá'(grifo nosso), porque a gente plantava tudo forrado com capim, empalhado, tudo forrado...mas esse capim não tem mais aqui. (G.C.)

Alho...mas parei de produzir porque não compensa mais, eu comprei carro tudo com o dinheiro do alho, hoje eu não produzo mais por causa do valor e da doença, não tem apoio para produzir, porque a terra e o clima é próprio pro alho, mas tem que preparar a terra, mas não tem agrônomo que ajuda a gente...e tivesse apoio eu deixaria o gado e plantava alho, eu fui criado plantando alho. (C.H.G.)

Sempre plantei alho...com mil quilos de alho você comprava um sítio de 10 alqueire, ganhava dinheiro vendendo alho...uma safrinha de alho era a salvação da propriedade, tinha gente que plantava aqui e comprou um caminhão...hoje a gente ganha dinheiro na propriedade, mas não consegue comprar oque comprava a vinte anos atrás...hoje a gente produz e vende, num tempo jogava fora...alho tinha ano que não acha de vender e jogava tudo fora. (C.D.G).

É importante destacar, que foram as mudanças do uso e ocupação do solo com as plantações de cana-de-açúcar e as pastagens formadas com braquiária, que contribuíram de forma negativa com a sócio-biodiversidade regional, seja na pressão exercida para o êxodo rural comumente relatado, ou na diminuição de dois tipos de capins específicos para o cultivo de alho na região. É pertinente pensar sobre a perda de espécie vegetal de valor econômico agregado, como o caso dos tipos de capim 'Rabo-de-boi' e 'Jaraguá'.

Em relação ao uso da terra no passado e as consequências no presente, observamos que as transformações tiveram grande influência da cultura canavieira, além disso, identificamos nos relatos a falta de assistência técnica:

Esses pequenos que saíram da terra, na maioria aqui que desistiram em foram para cidade venderam pros grandes, que formou tudo em cana ou tudo em pastaria, por isso tem esses pastos tudo abandonado. (S.S.F.)

Antes era melhor, hoje tem muito gasto com as coisas, até a terra era melhor, esses veneno mata-mato e a cana piorou a terra...o sítio piorou muito, o imposto é caro, nós que temos propriedade não temos ajutório, esses "sem terra" tem mais ajuda do que a gente, aqui ninguém vem ajudar, mas pra eles tem um monte de coisa, e eles não aproveita, aqui ninguém vem. (J.R.S.)

...quinze anos atrás colhia sempre 3 mil saca de milho, parei porque já não tinha mão de obra e começou a ficar caro produzir e vender muito barato, então era prejuízo.....aqui na terra não compensa mais plantar milho...nós tinha plantação de arroz na várzea...á vinte anos atrás eu tirava mais de 1000 litros de leite, agora é cana. (O.B.)

Sobre implementos agrícolas, a grande maioria das unidades produtivas possuem algum tipo de maquinário necessário para as atividades na terra, enquanto alguns não tem nada. Entre os maquinários aparecem: trator, sulcador, cultivador, lâmina, conchinha, arado, grade, pulverizador, maquinário de granja, carreta, plantadeira de milho, colhedor de milho, 
resfriador, tanquinho de leite, centrífuga de mel, picadeira, debulhador de milho, máquina de limpar arroz e equipamentos de irrigação:

\footnotetext{
"Tenho tudo velho".

"Tenho tudo, trator traçado, grade, carreta, pulverizador".

"Trator arado grade plantadeira de milho e colhedor de milho, implementos em geral".

"Trator 'véio', grade, arado, roçadeira, carreta."

"Trator, picadeira de cana, pulverizador, grade, arado, roçadeira....tudo parado".

“Tenho irrigação, mas 'oce' num vai dedar nós porque não tem licença de outorga para usar de água".
}

Agrupamos o que chamamos de diversidade de produção e autoconsumo em três níveis, definidos por critérios que relacionam o que é produzido na propriedade, tanto para autoconsumo como para geração de renda (Figura 5). Consideramos unidades produtivas com diversidade agrícola ALTA, as propriedades que tem maior produção de produtos para o autoconsumo e excedente para venda; MÉDIA, aquelas que têm diversidade agrícola apenas para o autoconsumo; e BAIXA, aquelas propriedades que produzem pouco ou muito pouco para o autoconsumo.

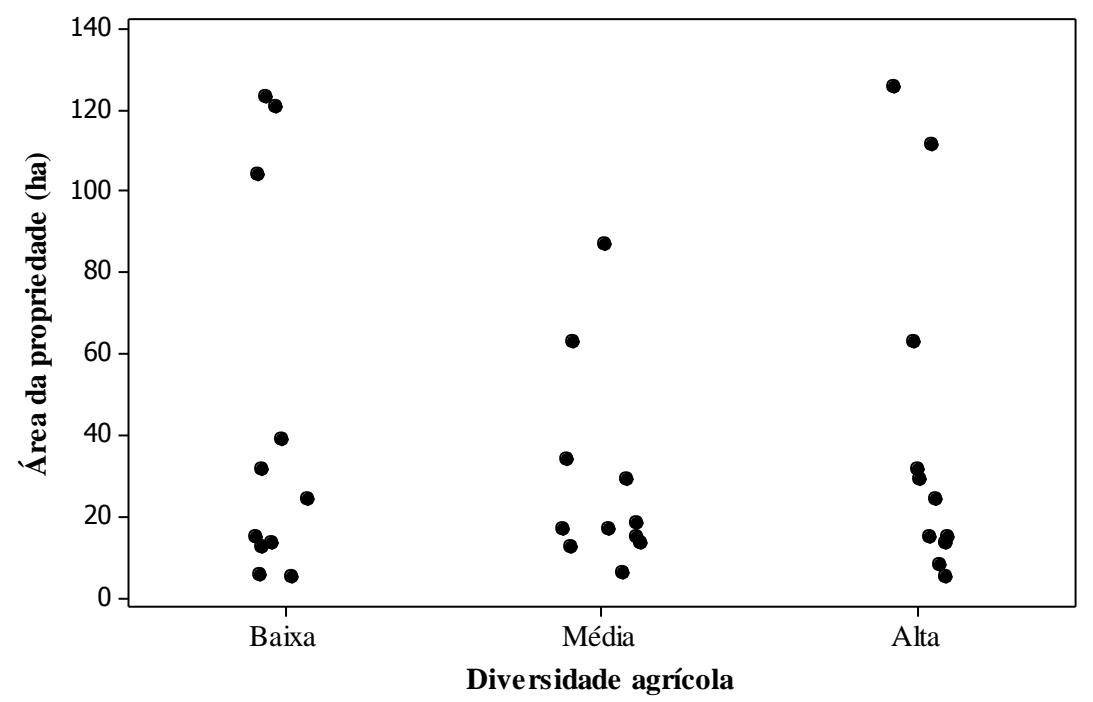

Figura 5 - Relação entre tamanho da propriedade e diversidade agrícola 
Os dados indicam que existem na APA Corumbataí pequenas ilhas de produção dentro dos oceanos de monocultura e pastagens, onde as propriedades classificadas no sistema agrícola e de sistema misto aparecem entre aquelas de alta biodiversidade agrícola (Tabela 4).

Tabela 4 - Resgate e listagem livre dos itens para autoconsumo e comércio nas unidades produtivas.

\begin{tabular}{|c|c|c|}
\hline $\begin{array}{c}\text { Diversidade agrícola } \\
\text { Alta }\end{array}$ & $\begin{array}{c}\text { Diversidade agrícola } \\
\text { Média }\end{array}$ & $\begin{array}{c}\text { Diversidade agrícola } \\
\text { Baixa }\end{array}$ \\
\hline $\begin{array}{l}\text { mandioca, pera, goiaba, coco, } \\
\text { banana, caqui, acerola, abacate, } \\
\text { abacaxi, cambuci, figo-da-índia, } \\
\text { lima-da-pérsia, laranja, louro, } \\
\text { figo, pinha, fruta-do-conde, } \\
\text { salsa, manga, limão-cavalo, } \\
\text { losna, abobora, limão-galego, } \\
\text { cebolinha, tomate-cereja, vinho, } \\
\text { mel, amendoim, seriguela, } \\
\text { pêssego, maçãzinha, pepino, } \\
\text { feijão, ovo, pimenta, pimentão, } \\
\text { maxixe, maracujá, galinha, } \\
\text { acerola, goiaba, manga, limão, } \\
\text { romã, salsa, leite, abacate, } \\
\text { mamão, jabuticaba, quiabo, figo, } \\
\text { tomate, alface, couve, requeijão, } \\
\text { coentro, leite, tomatinho-de- } \\
\text { horta, queijo, frango, cabrito, } \\
\text { porco, peixe, banha-de-porco, } \\
\text { cebolinha, carne de boi, farinha } \\
\text { polvilho, milho, horta, almeirão, } \\
\text { alface-lisa, melão, tomate, uva, } \\
\text { gengibre, taioba, jaca, cenoura, } \\
\text { beterraba, milho, alho, pêssego } \\
\text { tamarindo, caju, batata doce, } \\
\text { cara, alface americana, almeirão, } \\
\text { cebolinha, cheiro-verde, feijão, } \\
\text { abacate, jabuticaba, goiaba, lixia, } \\
\text { acerola, pêssego, nectarina, } \\
\text { berinjela, almeirão, chicória, } \\
\text { abobrinha, ameixa, batata-doce, } \\
\text { amora, carambola. }\end{array}$ & $\begin{array}{l}\text { mandioca, milho, hortaliça, ovo, } \\
\text { laranja, alface almeirão, } \\
\text { almeirão, couve, salsa cebolinha, } \\
\text { manga, coco, frango, porco, } \\
\text { queijo, pepino, maracujá, } \\
\text { banana, goiaba, caju, acerola, } \\
\text { jabuticaba, amendoim, feijão, } \\
\text { porco, frango, carneiro, } \\
\text { melancia, mamão, salsa, } \\
\text { verduras, amendoim, tomate, } \\
\text { laranja, limão. }\end{array}$ & $\begin{array}{l}\text { Banana, frango, galinha, } \\
\text { frutíferas, mamão, siriguela, } \\
\text { tempero verde. }\end{array}$ \\
\hline
\end{tabular}

Entre as unidades produtivas com baixa diversidade agrícola estão todas, sem exceção, as de sistema produtivo com pecuária, mesmo aquelas onde a ovinocultura é a atividade principal, justificam:

“plantar pouco não compensa, então eu compro";

"Nada, compro tudo no mercado"

"Por causa do frango eu não posso criar nada, nem galinha nem porco"

"Nada, aqui é ruim de água, e horta precisa de água" 


\footnotetext{
"Não tenho horta, não dá tempo pra tocar, é mais fácil comprar no mercado"

"Não faço horta porque tenho galinha, se planta milho os porco-do-mato derruba tudo, tudo que planta o porco estraga tudo"

"Só frutífera, nem horta tenho, eu compro do vizinho e na cidade"

“aqui não dá pra ter nada, fica perto desse mato grande, e os bichos mexe muito, macaco acaba com o milho, raposa pega galinha, o porcão mexe por tudo"
}

De forma geral, a diversidade agrícola ou a agrobiodiversidade deve ser enaltecida como altíssima nas unidades produtivas visitadas, mostrando a potencialidade da agricultura familiar na APA na produção de itens alimentares para o autoconsumo e comércio. Outro ponto que merece destaque, é que a alta diversidade em algumas unidades produtivas com muitas espécies "domesticadas", tanto animais, quanto vegetais, são essenciais na rica e complexa relação direta com espécies selvagens. Foi fato comum ouvir dos agricultores a respeito de predação ou simplesmente das perdas nas plantações ou das criações por lebres, porcos-do-mato, capivara, sanhaços, quati, jaguatirica, onça-parda, raposa e cachorro-domato, que de certa forma se beneficiam da presença deste tipo de agricultura existente numa região dominada por pastagem e monocultura. Nos dias de hoje, a existência de pequenas propriedades rurais com alta diversidade agrícola, ao seu modo, tem colaborado para a manutenção de diversas espécies de vertebrados, se não no Estado de São Paulo como um todo, ao menos na paisagem agrícola da Bacia do Corumbataí.

De modo geral, as famílias estudadas seguem uma ampla variedade de estratégias para obtenção de renda na propriedade, algumas destas famílias escolhem estratégias que envolvem a pluriatividade e como consequência parecem obter melhores condições e motivações para permanecerem na terra. Segundo uma classificação adotada por Guanziroli e Cardim (2000) os agricultores familiares podem ser classificados em três condições: 1consolidados, aqueles considerados diferenciados no setor por buscarem assistência técnica e de crédito, com boa capacidade de análise e gerenciamento; 2- em transição, produtores de menor conhecimento que os consolidados e com menor assistência técnica e crediário, e menor análise de gerenciamento; e 3- periféricos ou de subsistência, aqueles que não possuem viabilidade econômica e tem dificuldades no gerenciamento da propriedade. A partir desta generalização foi possível caracterizar em três tipos os agricultores familiares na APA:

- Agricultores familiares marginalizados e menos competitivos, dependentes de uma política de assistência e que provavelmente deixem de existir, acentuando ainda mais a desertificação do espaço rural: 
Eu já mandei 300 litros de leite por dia, isso tem seis meses, eu tinha ordenhadeira, tinha balão...mas não tem condições, os grandes produtores de leite na região acabaram com os pequenos...não compensa com o preço, agora nas águas melhora, mas na seca a gente não consegue, porque tem que gastar com ração...no começo há uns 5 anos, era bom...ai eu gastei minhas economia e não melhora nada...num tem assistência. (J.A.)

Uma das causa de abandono dos agricultores foi a ida para a cidade trabalhar para indústria de cestas-básicas...o sujeito vende o sítio ou arrenda e vai morar na cidade pra trabalhar pro outros...por um lado foi bom ir pra cidade...só que tirou o cara do sitinho...tem outra coisa, no sitio não tem mão de obra mais, ninguém quer mais morar no sítio, a cidade tem atrativo, por exemplo a empresa de "cesta básica" emprega muita gente, com salário e cesta básica, fica melhor que viver apertado no sítio. (J.A.)

Antes era melhor, hoje tem muito gasto com as coisas, até a terra era melhor, esses veneno mata-mato, piorou a terra. $\mathrm{O}$ sítio piorou muito, o imposto é caro, nós que temos propriedade não temos 'ajutório', esses sem terra tem mais ajuda do que a gente, aqui ninguém vem ajudar, mas pra eles tem um monte de coisa, e eles não aproveita, aqui ninguém vem. (J.R.S.)

- Agricultores familiares que se identificam como tais, menos capitalizados, menos tecnificados, mas capazes de pensar na agricultura como em termos de sua manutenção no campo e se aproximam dos modelos de agricultura de subsistência e pluriativa:

Hoje o pequeno produtor é subsistência, você pode ver com qualquer outro produtor, ao menos que ele tiver fonte de renda de outra coisa, aposentadoria alta, ou outros negócios, mas hoje a agricultura familiar é subsistência. Ninguém mais ganha dinheiro para fazer império, isso pode esquecer. Aqui eu falo é uma propriedade de subsistência, porque você vê, você planta, cheiro-verde, tem uma couve pro gasto, você cria um porquinho, então 'oce' tem aqui uma agricultura familiar mesmo. (G.C.)

Eu quero mexer com turismo, tenho a pista de motocross, faço uns encontros com forró... assim quero ter as coisas pra vender pra eles...quero fazer uma horta orgânica...hoje eu tenho gado de corte...crio uns carneiro e crio umas galinhas também, mas as jaguatirica andou comendo umas ai...eu planto eucalipto, arrendo o pasto...agora vou entrar na Cati-leite, eu fui numa reunião e eles me falaram disso na agricultura familiar, me interessei em mexer com ordenha agora. Eu não quero plantar cana, ela é um futuro nesse sistema, mas ela acaba com o solo. (A.)

- Agricultores familiares que se identificam como tais e são competitivos, mais bem tecnificado, com capacidade de adaptação ao ambiente e com maior autonomia em relação ao mercado e em vias de crescimento:

Nos últimos anos eu acho que eu ampliei, eu cresci, e vou crescer mais, o frango hoje ta bom, eu tenho hoje 3 granja, então pra mim melhorou, pq antes não dava nada. Uma coisa que eu queria investir era no coco-da--bahia, eu to com idéia de plantar, eu já plantei maracujá e não virou nada, só prejuízo, mas a terra parada eu decidi plantar um pouco de eucalipto. Eu tô cortando o eucalipto de 5 anos, porque eu preciso pagar o banco...eu vendi por 40 reais o metro em pé (lenha), isso pra mim tá bom, vendendo a 40 tá bom, se ficar isso ai, eu vou plantar mais, dá lucro. (C.C.B.) 
Eu acho que melhorou por causa dos empréstimos, eu fiz e já paguei, agora vou fazer outro, porque vou melhorar a granja...ai sobra tempo para eu mexer com o mel e eu ganho mais. É um investimento alto, mas o juros é baixo com 2 anos de carência, e hoje tem mais facilidade para mexer na terra por causa do financiamento, isso melhorou. (D.A.B)

As características gerais dos agricultores familiares da APA Corumbataí em relação às questões de uso, produção e renda, sugerem baixa tecnificação, baixo capital, nenhuma formação de rede social, pouca ou quase nenhuma assistência técnica e fortes relações com as cidades onde estão inseridos e centros maiores como São Carlos e Rio Claro, onde vendem seus produtos. De modo geral, os dados apresentados aqui indicam uma grande diversidade de situações no desenvolvimento da agricultura familiar na APA do Corumbataí, mas vão claramente além, comprovando a ideia de que boa parte destes agricultores pode deixar de existir na região, já que não há apoio técnico ou extensionista e nem mecanismo articuladores que fortaleçam sua permanência no meio rural. Esta caracterização está longe de ser esgotada, neste sentido, a APA Corumbataí é um locus de estudo privilegiado tendo em vista que agricultura familiar na APA é rica e merece atenção de pesquisas mais robustas por parte de estudiosos do assunto.

\subsubsection{Caracterização sócio-ambiental}

As questões ambientais neste estudo remetem ao estado atual dos recursos hídricos nas unidades produtivas investigadas, uma vez que $81 \%$ das propriedades visitadas possuem nascentes. Algumas destas nascentes se unem para formar pequenos corpos de água, e outras são os próprios córregos que irão desaguar diretamente nos rios Cabeça, Passa-Cinco, ou no próprio Corumbataí (Figura 6). Os recursos hídricos nas unidades produtivas têm a função de fornecer água, tanto para o consumo, quanto para produção animal e vegetal. 


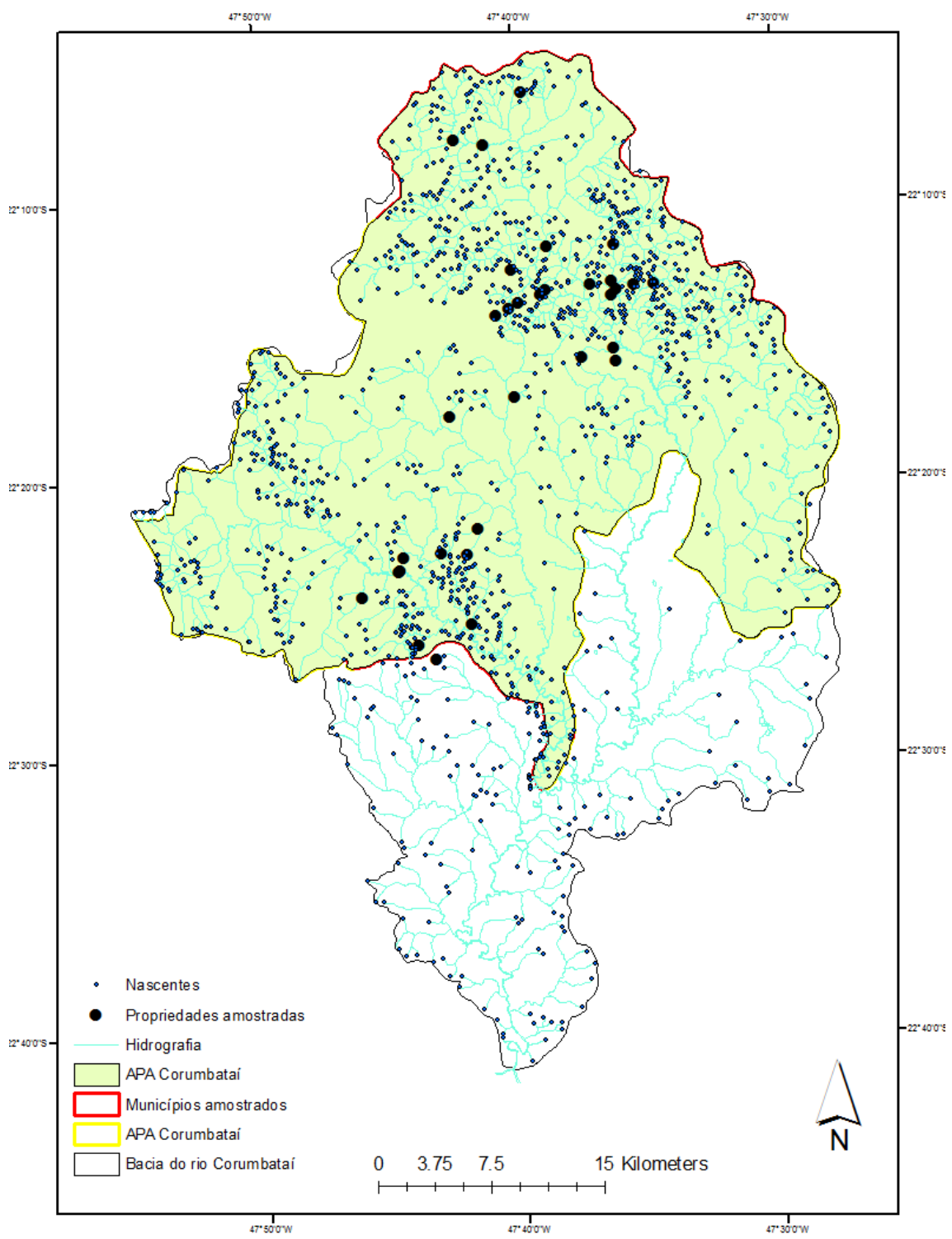

Figura 6 - Unidades produtivas visitadas e sua relação com a hidrografia

Com a crescente demanda para conservação dos recursos hídricos da região estudada, os dados aqui apresentados representam o estado atual desses recursos nas unidades produtivas visitadas. De forma geral, as informações apontam para elevada sensibilidade destes ambientes hídricos nas propriedades. A questão da qualidade ambiental dos recursos hídricos nas unidades produtivas foi avaliada de maneira subjetiva (observação em campo). Conforme descrito anteriormente referente às questões hídricas nas unidades visitadas, verificamos a qualidade das nascentes, observando se eram cercadas, presença de vegetação ciliar, áreas de reserva legal, áreas de preservação permanente com vegetação nativa ou exótica, além da própria relação do público alvo sobre estas questões (Tabela 5). 
Tabela 5 - Informações gerais a respeito dos recursos hídricos nas propriedades amostradas

\begin{tabular}{|c|c|c|}
\hline Variáveis observadas & $\begin{array}{l}\text { Números } \\
\text { absolutos }\end{array}$ & $\begin{array}{c}\text { Porcentagem } \\
\text { correspondente }\end{array}$ \\
\hline Total de entrevistas & 33 & $100 \%$ \\
\hline Total de nascentes & 76 & $100 \%$ \\
\hline Propriedades com nascentes & 27 & $81 \%$ \\
\hline Propriedade com corpo d’água (rios ou córregos) & 29 & $88 \%$ \\
\hline Mata ciliar presente na propriedade & 15 & $45 \%$ \\
\hline APP presente & 30 & $91 \%$ \\
\hline APP cercada & 9 & $27 \%$ \\
\hline Vegetação exótica na APP & 11 & $33 \%$ \\
\hline Vegetação nativa na APP & 11 & $33 \%$ \\
\hline Vegetação nativa e exótica na APP & 8 & $24 \%$ \\
\hline Sem vegetação na APP (solo exposto) & 3 & $9 \%$ \\
\hline Sabem o que é APP & 24 & $72 \%$ \\
\hline Sabem o que é RL & 26 & $79 \%$ \\
\hline Fragmento de floresta nativa na propriedade & 28 & $85 \%$ \\
\hline Usa água de dentro da propriedade & 25 & $76 \%$ \\
\hline Usa água de fora da propriedade & 5 & $15 \%$ \\
\hline Usa água de fora e de dentro da propriedade & 3 & $9 \%$ \\
\hline Relação com a água (nascentes, rio, córrego) - não sabem & 6 & $18 \%$ \\
\hline Relação com a água (nascentes, rio, córrego) - sempre igual & 14 & $42 \%$ \\
\hline Relação com a água (nascentes, rio, córrego) - melhorou & 3 & $9 \%$ \\
\hline Relação com a água (nascentes, rio, córrego) - piorou & 10 & $33 \%$ \\
\hline Erosão na propriedade & 16 & $48 \%$ \\
\hline Sabem sobre APA & 0 & $0 \%$ \\
\hline Sabem sobre PCJ & 7 & $21 \%$ \\
\hline Sabem sobre PSA & 8 & $24 \%$ \\
\hline Sabem sobre Código Florestal & 0 & $0 \%$ \\
\hline
\end{tabular}

No universo da pesquisa levantamos a existência de 76 nascentes na área de estudo, sendo possível avaliar in loco $70 \%$ delas, geralmente aquelas mais próximas das sedes das unidades produtivas. Muitas destas checagens em campo ocorreram com a presença do entrevistado. Nas 33 unidades produtivas, apenas quatro não tem relação direta com cursos d'água ou nascentes, e recebem água das unidades vizinhas numa espécie de política de boa vizinhança, que é chamada de "servidão", quando o detentor de uma ou mais nascentes fornece água para a unidade vizinha. Em vinte e sete unidades produtivas há ao menos uma nascente, e em apenas uma delas existem sete nascentes, dois córregos e um rio, o Corumbataí. Quando questionados sobre a realização de alguma prática conservacionista em detrimento ao recurso hídrico, seja o rio, córrego ou nascente, apenas sete entrevistados dizem 
adotar alguma atitude em relação a isto, citando, na maioria das vezes curva de nível e controle de erosão. Segundo os informantes, em 17 unidades produtivas visitadas existem erosão do solo e assoreamento dos cursos d'água. Valente e Vettorazzi (2003) já apontaram para a perda da capacidade produtiva por erosão dos solos comprometendo a hidrologia da Bacia.

Conforme vimos anteriormente, as unidades produtivas foram separadas entre padrões de uso da terra como, agricultura, pecuária ou mista, com características sociais e econômicas similares, mas que podem ter impactos ecológicos diferentes. Ao observamos a existência e o estado das áreas de preservação permanente (APP), podemos dizer seguramente que apenas nove estão totalmente cercadas e com exclusividade de vegetação nativa, as demais compreendem vegetação nativa e exótica, principalmente braquiária e não estão cercadas. Entre os entrevistados, sete não souberam responder aos questionamentos sobre APP:

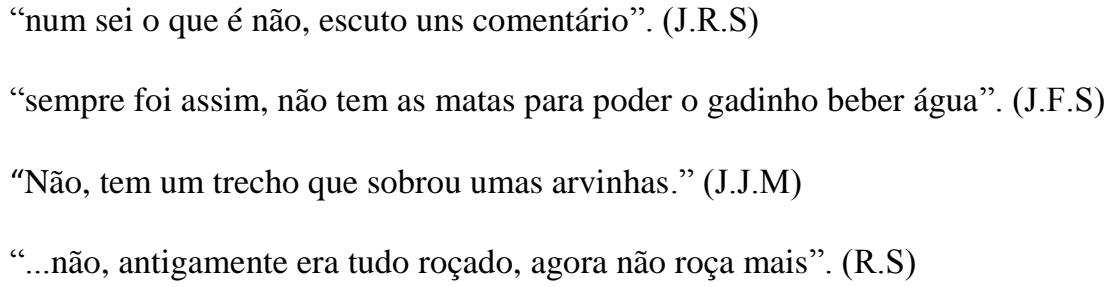

Entre aqueles que sabem o que é, e a importância das APP's, foi possível obter os seguintes depoimentos:

Sei o que é, acho bom, conserva a nascente, antigamente tirava tudo, agora tem que deixar, a lei é a lei, mas é importante deixar por que vai desbastando e vai criando erosão. (N.N)

...e esse negócio de cercar beira de rio não tem jeito, como é que eu vou fazer pro meu gado atravessar e ir beber, se tiver que fazer ponte quem vai fazer, boi não travessa pinguela...o gado meu atravessa o rio porque eu tenho pasto dos dois lados. (S.C.B)

"Sim, quero fazer no meu, eu sou a favor da vegetação na beira do rio, os outro são contra...eu quero plantar umas frutíferas, que dê fruta” (J.M.N)

"Sim, eu acho certo...todo mundo tinha que preservar, você vê as usinas, elas planta até dentro do rio".(J.A)

Muitas vezes os entrevistados não tinham relação direta com os corpos d'água maiores dentro da APA, como os rios Passa-Cinco, Cabeça e o Corumbataí. No entanto, quando estes rios maiores passavam por suas propriedades foram realizados questionamentos sobre a qualidade/sanidade dos rios: 
...antes do rio ser dragado existia muito peixe, muito curumbatá, tinha pra “daná”...só perdeu o Corumbataí na parte de criar peixe, porque acabou as lagoas que formava as várzea. (G.C)

...piorou depois do areeiro, acabou com os peixes, já faz uns 30 anos que o rio vem acabando, depois da dragagem, pra endireitar o rio lá em Ferraz...o que aconteceu é que agora os barrancos são mais largos e mais fundo, e vai continuar aumentando, vai assoreando. (J.M)

A qualidade do rio piorou, o loteamento joga tudo esgoto dentro do rio, até uns cinco anos atrás pra quem gostava de pescar era só vim com a varinha pegava um monte, tenta pega um lambari hoje. (J.B)

...o Passa-Cinco fracassou, antes era melhor, acho que é a cana e a terra encheu o rio, assoreia, as curva de nível são mal feitas. (J.R.S)

“...água tá tudo mais ou menos como era, água sempre foi do mesmo jeito com mato e sem mato". (O.B)

...piorou, piorou muito esse rio mesmo corria quase que o dobro, porque essas nascentes minhas eu preservei, eu plantei árvore...se eu não tivesse feito isso eu minha água que tá aqui não tinha mais. (J.D)

Os entrevistados afirmam que nas unidades produtivas investigadas existe ao menos uma área com fragmento florestal nativo, sendo frequentemente pequeno e basicamente formado por floresta secundária (capoeira abandonada). Nas entrevistas muitos souberam responder sobre Reserva Legal na propriedade e também averbação da área:

Já ouviu falar, mas não tem averbada, tem um mato aqui de mais ou menos 2 hectares...estamos esperando pra ver como fica a legislação, se vai somar a app. (C.D.G)

...ouvi falar e não tenho eu não teria que ter porque sou pequeno, mas se vier a lei a gente é obrigado a fazer. Inclusive eu vi um debate que a mata ciliar devia ser englobado na reserva legal, ai eu deixo...esse negócio do meio ambiente tá complicado pro pequeno, pensando no planeta tinha que ser, mas para o sistema econômico do pequeno tá complicado. (C.H.G)

sim, tenho aquele matinho e lá em baixo também tenho um pouquinho e plantei 60 mudas de árvore em volta da represinha, eu sou de acordo, se tiver que averbar sou a favor. (D.P.A)

A pequena propriedade não tem como, eu tenho uma quarta de terra, que pode ser averbado, tenho até palmito plantado, mas é tudo formado em eucalipto no resto, é uma mata que eu não mexo, aqui eu tenho meio alqueire com mato e palmito nativo. (D.A.B)

...já estamos indo atrás para averbar, mas pra nossa propriedade que é pequena, se tirar os $20 \%$, mais as app, beira dos rios, topografia ruim, acaba diminuindo muito a área do proprietário. (A.B)

Eu tenho um capão de mato ai, eu tenho muito mais que os vinte por cento, mas não ta averbado...governo devia valorizar, quem tem, não vim aqui me multar, porque essa matinha minha ai, não forma nem em dez e nem em vinte anos, vai ver o que é mato, tem pau grosso. (J.M) 
Eu tenho uma boa parte, mas não tá averbada, pro pequeno produtor é muito, já tenho pouco se eu deixar 20 por cento, ai sobra pouca terra. (N.N)

Já ouvi falar e não tenho, acho justo que tem que preservar, mas no meu caso eu não posso perde 2,5 alqueire para trás de uma terra boa, de um terreno plano, vou ter que largar e plantar árvore se podia plantar alimento. (J.B)

...sim, eu declarei essa reserva no ITR, se você andar na beira do rio aqui a melhor conservação é aqui no meu...do meu lado eu tenho, mas que adianta, o vizinho não tem nada. (J.R.S)

Eu tenho mais que $20 \%$ e já tá averbada para reserva legal, mas eu não sei se pode ser, porque tem um negócio de $45 \%$ de declive e não vale mais, eu não sei dessas coisas direito. Com esses topo de morro e com as minas e o córrego, eu tenho mais, os brejo eu protejo nem mexo, poderia ter uns porco, mas nem mexo. (J.D)

Entre os entrevistados não há quem saiba o que é, ou mesmo que reside dentro de uma unidade de conservação ambiental na categoria APA. Poucos souberam responder aos questionamentos a respeito de políticas públicas como Pagamento por Serviços Ambientais PSA, sendo que, na maioria das vezes se reportavam a esta questão falando que viram alguma coisa em Minas Gerais. Da mesma forma, apenas sete dos entrevistados já tiveram contato ou sabem a respeito dos serviços prestados pelo consórcio CBH-PCJ na Bacia:

Sim, mas o pessoal do PCJ vem aqui, e não faz nada, ó a situação do rio... ninguém faz nada, eles nunca fizeram nada, ninguém explica nada, vieram aqui e me multaram, e sempre usei... eu não tenho informação. (J.M)

Eles nem sabem me falar de onde eu tenho que medir os trinta metro, cada um fala uma coisa. Eu não to recusando preservar o rio Corumbataí, mas todo mundo tem que preservar...ali na Jundú, na mineração, os caras lava aquela areia, e a água é uma sujeira desgraçada, mata peixe, ninguém fala nada. (J.M)

PSA já ouvi, uma lei em Minas, eu acho que isso ta certo, porque se perde a terra, e não pode produzir nada, agora para receber seria bom, preservar, se receber a gente deixa formar tudo em capoeira.(N.N)

"PSA...já ouvi falar, mas não sei o que é, nem para que serve". (J.B)

PSA, não sei, mas o PCJ já ouvi, falar, e isso tá complicando para nós, onde vai os esgoto, não adianta querer plantar árvore no sítio e não cuida do esgoto da cidade. (S.C.B)

O pessoal do consórcio da Bacia do Piracicaba vai me mandar 10257 mudas para plantar ali no córrego e ao lado dos tanques, isso ai é pra conservar as minas. (A.)

"PSA não...teve um rapaz que veio aqui uma vez do comitê da Bacia mas nunca mais voltou". (M.S)

PSA não....esses da Bacia do Piracicaba, eles tem que vim aqui ver que eu tenho bastante água, eles falam que vem aqui plantar, nós não somo obrigado dar água pra Piracicaba, se eles quiserem eles podem plantar, eu não vou plantar, eu não tô acabando com a água, eu tenho 5 nascente, a gente com o negócio de proteger a água nós tem prejuízo por que não pode plantar perto da água, o gado não pode 
beber, se eu for cercar tudo os meu rio vai um mundo de arrame um mundo de madeira, acho que eu tenho uns $4 \mathrm{~km}$ de rio, mais os córrego, mas as cabeceira, fica caro isso, se acha que vão fazer, é muita despesa. Eu produzo água. (O.B)

Sim, veio um pessoal aqui ano passado, e eu fui numa reunião em na prefeitura, mas ninguém voltou mais, pediram para separar documentos, falaram, mas eu não sei de mais nada. (J.D)

Os entrevistados atribuem funções ao Comitê PCJ que não são atribuições da instância gestora. Contudo, por julgarem a instituição desta forma ou por não conhecerem seu papel, acabam não se aproximando, comprometendo assim o modelo de governança descentralizada e participativa proposto. Os resultados apontam que a maioria das propriedades está longe de cumprir sua função ambiental, pois não compartilham integralmente todas as características necessárias e legais na relação com os recursos hídricos. Sabe-se, que os recursos hídricos que não compartilham das características preconizadas nas leis ambientais do Brasil tendem a ser susceptíveis ao esgotamento e à degradação. Da mesma forma, como sugerido anteriormente, a relação da agricultura familiar na APA com os recursos hídricos é meritória de estudos, bem como, sua inclusão nas propostas conservacionistas.

\subsubsection{Discussão}

Os resultados sugerem que os habitantes da APA Corumbataí apresentam características sociais, econômicas e ecológicas que se relacionam e influenciam nos processos de conservação da natureza e dos recursos hídricos. Dessa forma as contribuições nessa discussão serão norteadas no sentido de mostrar primeiro, quem são os agricultores familiares, em seguida contextualizar como eles se relacionam com os recursos hídricos, e finalizar com uma concepção original que aponta para importância dos agricultores familiares na conservação ambiental.

Para Lamarche (1998), a exploração familiar corresponde a uma unidade de produção agrícola, onde a propriedade e os trabalhos estão intimamente ligados à família. Na APA, os produtores rurais, mulheres, filhos, genros, noras e agregados perfazem um total de 74 pessoas envolvidas diretamente com as atividades da propriedade para geração de renda ou autoconsumo, caracterizando o tipo de exploração nas unidades produtivas como tipicamente familiar. Este cenário, observado em uma das regiões mais desenvolvidas do estado de São Paulo, é similar ao encontrado em diferentes regiões do país, onde a população rural tem a propriedade como sua principal fonte de trabalho e renda (MOREIRA, 2008, HURTIENNE, 1999, GUANZIROLI et al., 2012, SCHNEIDER, 2001). 
Lamarche (1993) sugere diferentes modelos teóricos de funcionamento dos estabelecimentos rurais, definidos a partir de lógicas de pequenos produtores familiares e grau de dependência, onde as estratégias podem ser muito familiar, medianamente familiar e pouco familiar. Os modelos concebidos seriam: 1- empresa: pouco familiar e fortemente dependente; 2- empresa familiar: distingue-se do modelo anterior pelo papel primordial da família, 3- agricultura de subsistência: funcionam mais no modelo de sobrevivência e, 4agricultura familiar moderna: menor papel da família e maior autonomia. Lamarche (1993), ainda classifica os agricultores segundo suas estratégias fundiárias como os empreendedores, os satisfeitos, os resignados e os frustrados.

$\mathrm{Na}$ APA Corumbataí retratamos três tipos de agricultores familiares e por analogia aos modelos propostos, sugere-se a existência de:

- Agricultores familiares que se identificam como tais e são competitivos, mais bem tecnificados, com capacidade de adaptação ao ambiente e com maior autonomia em relação ao mercado e em vias de crescimento. Neste grupo aparecem as unidades produtivas onde a exploração da terra diretamente pelo proprietário não é a única possível, entre estes estão os que arrendam terra para cultura canavieira e/ou possuem granjas integradas com cooperativas ou firmas privada. Esse tipo de produtor revela características que Lamarche (1998) chama de modelo empresa, do sistema dependente, onde a dependência se exerce tanto no plano tecnológico quanto no financeiro. São produtores satisfeitos e empreendedores.

- Agricultores familiares que se identificam como tais, menos capitalizados, menos tecnificados, mas capazes de pensar a agricultura em termos de sua manutenção no campo e se aproximam aos modelos de agricultura de subsistência e pluriativa. Essas características colocam esses produtores como muito familiares, satisfeitos, mão-de-obra principalmente familiar e o futuro da unidade de produção é pensada em termos de reprodução e continuidade do modelo, portanto, empresa familiar proposta por Lamarche (1998).

- Agricultores familiares marginalizados e menos competitivos, dependentes de uma politica de assistência e que provavelmente deixem de existir, acentuando ainda mais a desertificação do espaço rural. Com estrutura fundiária pequena, tipo de uso e ocupação da terra inapropriados, sendo a maioria nas atividades de pecuária bovina, colocam esses agricultores da APA como medianamente familiares e nas categorias cunhadas por Lamarche (1998) como resignados ou frustrados. Grosso modo, não se encaixam nos modelos de agricultura de subsistência, já que estes estão entre aqueles que classificamos anteriormente com baixa diversidade agrícola. 
De forma geral, Graziano da Silva (1997), já havia descrito as estruturas agrárias e a produção de subsistência na agricultura brasileira, e que nos estabelecimentos com até 50 hectares estavam concentrados a agricultura para o abastecimento interno do país, principalmente de produtos alimentares. Segundo Altieri (2004) na América Latina cerca de 60 milhões de hectares (38\%) de terras agricultáveis são utilizadas pela agricultura familiar, e no Brasil 50\% da produção de alimentos é destinada exclusivamente para segurança alimentar das famílias produtoras. De fato, neste estudo foi possível constatar que esta ainda é uma realidade na APA, onde encontramos alta diversidade de alimentos e produtos produzidos para o comércio, desde os vendidos in natura até os processados. Por sua vez, Lamarche (1998, p.28) tratou estes estabelecimentos de "minifúndios improdutivos", econômica e socialmente inviáveis, que incorporam a agricultura de base familiar no país, mas que, no entanto é uma realidade, e o potencial deste grupo, frequentemente é desperdiçado.

No caso estudado, através de assistência técnica e extensão universitária, esse desperdício ou essa realidade poderia ser diferente ao incluir a questão ambiental e dos serviços ecossistêmicos da propriedade rural, de tal modo, que os estabelecimentos menores passariam a ter conotação de minifúndios produtivos. Neste caso, Verdade (2004), quando trata da questão da conservação em paisagens agrícolas, sugere que na estrutura da CATI deveria haver em seu quadro técnico, além de agrônomos e veterinários, também técnicos das ciências naturais como, por exemplo, biólogos ou gestores ambientais que por sua vez auxiliariam na solução de problemas ligados à biodiversidade e recursos hídricos, proporcionando inclusive práticas de produção mais sustentáveis e com geração de renda. Além disso, a estrutura acadêmica regional deveria por sua vez, fomentar a extensão universitária, um dos pilares da estrutura do ensino superior. Na Bacia do Corumbataí especificamente na Serra de São Pedro, um exemplo de extensão rural vem sendo desenvolvido e obtendo resultados positivos com a participação dos produtores rurais na preservação de matas ciliares com diversidade produtiva e conversão agroecológica dos estabelecimentos (DE LUCAS et al., 2010). A ausência de extensão rural, de caráter sócioambiental, é identificada como uma dos principais lacunas e entraves para o desenvolvimento socioeconômico e ambiental da população rural (BRONDIZIO; MORAN, 2008, ALVES et al, 2006). Neste sentido, há necessidade de uma proposta de estruturação por parte dos gestores da APA, gestores da Bacia, CATI e municípios para atender a demanda destes agricultores, no que tange a oferta e produção de alimentos e melhoria dos serviços ambientais. Há na política federal um plano nacional para promoção dos produtos das sociobiodiversidade (PNBSB) que visa promover a conservação e o uso sustentável da 
biodiversidade, garantindo alternativas de geração de renda para as comunidade rurais. Posterior a isso, pode-se pensar propostas de certificação mista de serviços ambientais, contribuindo com a conservação da biodiversidade e a permanência dos agricultores no campo.

O presente estudo trata tão somente das relações do agricultor familiar da APA Corumbataí com o meio natural, mas de certa maneira perpassa pela forma que o agricultor busca no seu modo de vida, meios de obter suas necessidades básicas. Nesse sentido, Candido (2001, p.36), aponta que é na busca para obtenção das necessidades básicas, que há a incorporação do homem com a natureza, o que demonstra um caráter de sequência ininterrupta e de continuidade que existe nas relações deste grupo com o meio. Por esse motivo, o homem e o meio aparecem numa solidariedade indissolvível. Dessa forma, o meio natural aparece para o caipira como um celeiro, que é utilizado indiferentemente, de tal forma que as atividades homem/meio natural, são por sua vez uma continuidade, do que Candido (2001, p.222) chama de "um interajuste ecológico, a bem dizer, dois pólos de uma mesma realidade”. Esta colocação continua fazer sentido nos dias de hoje e principalmente nesta pesquisa, quando tentamos relacionar Agricultura Familiar e Conservação Ambiental. Para alguns autores a agricultura familiar é diversificada em seus processos de interação e uso do meio, tendo assim maior proximidade com a sustentabilidade (estabilidade, resiliência e equidade ambiental) (VEIGA, 1996, MOREIRA, 2008).

De tal modo, um ponto importante a ser considerado nesta discussão, diz respeito à diversidade agrícola nas unidades produtivas visitadas, tanto de produtos de origem vegetal, em sua maioria, quanto animal, como bovinos, caprinos, ovinos e aves. Ainda que o nível e a qualidade dessa produtividade parecem afetar de forma significativa os recursos naturais, comprometendo a capacidade suporte natural das unidades produtivas, bem como sua continuidade na BHC, ela se aproxima das discussões em voga na literatura referentes à agricultura ecologicamente sustentável proposta por Veiga (2003). Além disso, se aproxima do que o autor se refere ao termo "sociobiodiversidade" ao remeter-se à temática da agricultura "ecologicamente sustentável” (VEIGA, 2003) em contraposição aos conflitos da agricultura convencional de larga escala. Nesse caso a sociobiodiversidade agrega as relações entre bens e serviços gerados a partir dos recursos naturais voltados à formação de cadeias produtivas de interesse das comunidades tradicionais e de agricultores familiares (MDA, 2011). É nesse sentido que a produção agrícola nas unidades investigadas e inserem na temática da sociobiodiversidade, já que agrega as relações entre bens e serviços gerados a partir do uso comum dos recursos naturais. 
Almeida (1997), já coloca que esta importante relação é a ideia de desenvolvimento rural sustentável, ideia esta defendida atualmente por muitos pesquisadores, e que seria capaz de enfrentar com novas soluções a crise social e ambiental. $\mathrm{O}$ autor sugere a necessidade da concepção de desenvolvimento que tenha nas prioridades sociais sua razão-primeira, da mesma forma, no presente estudo observamos que estas ações são urgentes e necessárias na região de estudo se quiserem manter os agricultores familiares na terra. Neste caso, na BHC por serem pequenas, as unidades produtivas investigadas neste estudo, aparentemente tem um papel crucial na conservação, isso porque suportam e detém mais biodiversidade do que as áreas com pastagens e cana-de-açúcar, além de causarem menos impactos nas áreas de Áreas de Preservação Permanente e Reserva Legal. Nesse caso, os agricultores familiares podem ser considerados como verdadeiros guardiões da biodiversidade nas paisagens agrícolas.

Independente da região do país, a biodiversidade agrícola nas unidades produtivas tem favorecido a geração de serviços ambientais, pois possuem um maior numero de sistemas naturais auxiliares na recuperação do ecossistema como um todo (GUILHOTO et al., 2004). Outros autores têm apontado que alguns agricultores são capazes de criar técnicas sustentáveis de produção e gestão do meio (ALMEIDA, 1988; DIEGUES, 1996; GALIZONI, 2000; COLCHESTER, 2000), considerando, portanto que a agricultura familiar pode assegurar um relacionamento mais amigável com o meio ambiente, especialmente no que diz respeito ao uso de recursos naturais (OLIVEIRA; ALTAFIN, 2008). De certa forma, estas mesmas relações estão presentes na APA Corumbataí, já que, nas unidades produtivas visitadas, principalmente naquelas que adotam sistemas de produção mista e agrícola, foi possível constatar alta agrobiodiversidade. Defende-se assim, a ideia que áreas da agricultura familiar, como produtora de alimentos e atreladas à temática da sociobiodiversidade, passem a ser entendidas como áreas prioritárias para conservação em paisagens agrícolas, por servir de reservatório de biodiversidade nestas paisagens. Em nove propriedade obteve-se listagens livres de espécies agrícolas a média de 114 itens alimentares e silvestres de interesse humano, itens estes que beneficiam tanto a alimentação e venda, como, a biodiversidade de vertebrados da região, principalmente aves e mamíferos silvestres. Portanto, não incorporar este grupo de agricultores nas práticas conservacionista seria realmente um desperdício.

Alguns autores como Abramovay (2003), Altieri (2004), Bonnal e Maluf (2009), Campanhola e Silva (2000), Gehlen (2004) e Veiga (2001), que abordam desenvolvimento e gestão dos recursos naturais nas áreas rurais, ou sobre a ótica das "novas" ruralidades, chegam apontar estratégias de construção de politicas ambientais e de desenvolvimento rural associado. No entanto acreditamos que, políticas públicas eficientes dispensariam políticas 
sociais e ambientais compensatórias, uma vez que as políticas rurais, como por exemplo, as políticas do PRONAF, priorizam apenas a garantia da subsistência e manutenção, excluindoos do progresso social. Ou seja, as políticas específicas para a agricultura familiar não oferecem igualdade de chances nas oportunidades, e tem racionalidades centradas em outros valores éticos, principalmente os relacionados à reprodução socioeconômica e ás relações com o meio natural. Da mesma forma, as políticas ambientais não se fazem cumprir, e as vezes quando se cumpre, tende a prejudicar o agricultor familiar, que muitas vezes não as conhecem e são multados, onerando ainda mais o pequeno produtor.

A análise da caracterização dos agricultores familiares da APA Corumbataí revelou que este grupo ainda vem se mantendo, produzindo alimento, se reproduzindo socialmente e interagindo com o meio natural. No entanto, distantes de quaisquer políticas públicas, sejam elas rurais ou ambientais. É neste sentido que trazemos a colaboração de Martins (2005), quando coloca que, com a participação e o fortalecimento das minorias locais nas esferas de "controle social do uso dos recursos naturais", é possível desenvolver áreas rurais no país. No mesmo sentido, Comin et al. (2009), sugerem que maiores esforços devem ser direcionados no que se refere ao envolvimento da população rural com disseminação das informações da atual situação da Bacia. Sugere ainda a urgência na integração entre comunidade local, pesquisadores e governança se o objetivo for a conservação da biodiversidade. Do mesmo modo, Martins (2007), ao analisar a política das águas no estado de São Paulo, interpretando os instrumentos de regulação ambiental na Bacia do Alto Paranapanema, sugere como política pública o entendimento da história social do lugar, de suas disputas materiais e cognitivas. Segundo Youné e Garay (2006, p. 57), é a partir da correta compreensão da complexidade destas questões sócio-ambientais e, principalmente considerando as interações humanas, que a implementação de políticas públicas de cunho ambiental torna-se possível.

Kageyama (2003), diz que no Brasil, a preocupação com as famílias do rural de baixa qualificação é limitada à produção de bens públicos (serviços ambientais) e a áreas de preservação ambiental. No entanto, aponta que a preocupação central da política europeia para o meio rural tem-se voltado menos para subsidiar os agricultores e mais para assegurar a conservação do ambiente, a produção de bens públicos correlatos (paisagem, espaço, hidrografia) e a prosperidade da população rural como um todo. Nessa linha, Martins (2005), afirma que, do ponto de vista institucional, é fundamental que haja articulação entre as políticas ambientais e politicas agrícolas e agrárias na regulação dos usos do solo e da água. Dessa forma é que podemos dizer que o conhecimento "ambiental" produzido pela comunidade científica, quando não incorpora o conhecimento local, torna-se demasiadamente 
estreito para poder fornecer subsídios suficientes para ações de conservação (COMIN; GHELER-COSTA; GARAVELLO, 2011; LIU et al., 2007).

Após expormos a compreensão e o entendimento de quem são os Agricultores Familiares da APA Corumbataí, seguimos para o segundo tema que atravessa o conjunto da área pesquisada, e diz respeito à relação desses agricultores familiares com os recursos hídricos. Durante o trabalho de campo observamos um número significativo de nascentes, rios e córregos, e verificamos que $91 \%$ possuem ás áreas de preservação permanente - APP. Dentre essas, $33 \%$ possuem vegetação nativa típica e com função de mata ciliar; $33 \%$ com vegetação exótica, como cana e capim; $24 \%$ com vegetação nativa e exótica, como capim e árvores isoladas; e 9\% sem vegetação (solo exposto), basicamente áreas assoreadas e de uso para o gado. Referente ao termo APP, $72 \%$ do público investigado conhecem o termo e referem-se a ele como "aquela área em volta das águas", no entanto poucos souberam responder sobre suas funções ecológicas e hidrológicas, normalmente referindo-se à presença de assoreamento. Percebe-se que na APA estudada as terras marginais aos cursos de água, que deveriam estar ocupadas por vegetação nativa confundem-se com áreas de atividade de lavoura ou pastagens. Este comportamento referente às APPs é um fator cultural na formação das comunidades agrícolas do Brasil (MARTINI; TRENTINI, 2011, MOREIRA, 2008), pois em sua maioria enxergam toda a área da unidade produtiva com possibilidade de utilização.

Do ponto de vista técnico/científico sabemos que a presença e manutenção das APPs, além da questão legal, deve-se ao seu relevante papel na proteção dos recursos hídricos e na composição de redes de corredores de vegetação nativa para a fauna e a flora, interligando os fragmentos, favorecendo desta forma o fluxo gênico na paisagem (GHELER-COSTA et al., 2012; RIBEIRO et al., 2009; RODRIGUES; BONONI, 2008).

Os dados coletados no presente estudo revelam que $85 \%$ das unidades visitadas detêm em sua área fragmentos florestais nativos em diferentes estágios de conservação. Para o público investigado a permanência destes fragmentos é uma obrigação legal; no entanto, a maioria não é averbada. Em todo o estado de São Paulo restam apenas 16\% de vegetação nativa distribuída em fragmentos florestais, em sua maioria, menores que 50 ha (RIBEIRO et al., 2009). Desta forma, a presença de fragmentos florestais mesmo que pequenos e/ou isolados, agrega favoravelmente possibilidades para adequação ambiental das unidades produtivas visitadas, bem como, para quaisquer propostas de cunho conservacionista para região, como por exemplo, corredores ecológicos. De acordo com o novo Código Florestal Brasileiro aos imóveis da agricultura familiar permite-se computar, na manutenção da reserva legal, árvores frutíferas, ornamentais ou industriais, além de poderem cultivar culturas 
temporárias. Para tanto programas de apoio técnico e financeiro deverão ser criados para estimular esses agricultores a preservar voluntariamente, proteger espécies da flora ameaçadas de extinção e recuperar áreas degradadas. Neste ponto, observa-se mais uma vez a ineficiência dos órgãos gestores, sejam eles municipais, estaduais ou institucionais, e chamamos a atenção que as ações relacionadas a manutenção e restauração das APPs nessas localidades merecem ser privilegiadas antes dos latifúndios sucroalcooleiro e pecuarista dominantes na região. Que por sua vez, estes últimos detém melhores condições e obrigação de conservar, seja por praticas agrícolas adequadas, seja pela busca de selos e certificações ambientais.

Atrelado ao exposto acima, por se tratar de uma unidade de conservação, o Sistema Nacional de Unidade de Conservação da Natureza (SNUC lei 9.985/2000), já prevê em seu artigo quarto, parágrafo $\mathrm{V}$, a promoção da utilização dos princípios e práticas de conservação da natureza no processo do desenvolvimento; no parágrafo VIII, determina proteger e recuperar os recursos hídricos; no XI valorar econômica e socialmente a diversidade biológica; no XIII, proteger os recursos naturais necessários à subsistência das populações humanas, respeitando e valorizando seu conhecimento e sua cultura, promovendo-as social e economicamente. Ainda segundo o SNUC, a categoria APA, além de fazer cumprir as determinações no SNUC, tem como objetivos básicos: proteger a diversidade biológica; disciplinar o progresso de ocupação; e assegurar a sustentabilidade do uso dos recursos naturais. Novamente ressalta-se ser necessário um plano de manejo e um conselho gestor que garanta dentre outras coisas, a qualidade de vida e bem-estar das populações humanas. O que preconiza o SNUC e o Código Florestal não se cumpre na APA, principalmente em relação aos recursos hídricos, suas áreas de preservação permanente e reserva legal.

De modo geral, o público investigado não é esclarecido da sua participação no processo de gestão e conservação destes recursos e, além disso, a maioria ignora a existência e os trabalhos do Comitê de Bacia Hidrográfica dos Rios Piracicaba, Capivari e Jundiaí (CBH PCJ), do Programa Estadual de Microbacias I e II da CATI (Coordenadoria de Assistência Técnica e Integral) e, sem exceção, não sabem que residem dentro de uma unidade de conservação do tipo APA reconhecida pelo SNUC. Neste estudo observamos, ouvimos e podemos afirmar que os "rurícolas" podem desconhecer um tipo de conservação, mais técnica e institucional, ou mesmo desconhecer sobre as organizações gestoras e regulamentadoras. Mas entendem a conservação do seu modo, como revelam alguns depoimentos anteriores sobre as alterações na qualidade da água, ou mesmo sobre a ictiofauna, quando o rio seria mais piscoso ou mesmo sobre a mortandade de peixes pela poluição. Freixedas (2012) sinaliza que existem diferentes ideias na relação sobre água, Bacia hidrográfica e área de 
preservação permanente entre proprietários rurais, técnicos ambientais e pesquisadores do tema e, que isso inferiria na conservação de recursos hídricos. A respeito dos diferentes olhares técnicos/científicos e dos agricultores, concordamos com Santos (2006), quando diz "o comportamento humano ao contrário dos fenômenos naturais não pode ser descrito, muito menos explicado com base nas suas características exteriores e objetivas, já que o mesmo ato externo pode corresponder a sentidos de ações muito diferentes”. Segundo Martins (2006), os agricultores possuem sim uma identidade de percepção e apropriação dos recursos, com acesso e práticas de manejo dos ecossistemas. E ainda assim, mesmo que distantes da função ecológica, a sua maneira os agricultores familiares investigados respeitam a APP e mantém as Reservas Legais.

Galjart (1979) coloca que o rurícola: "não sabe fazer outra coisa além daquela que tem feito até agora; sabe o que poderia fazer, mas é incapaz de fazê-lo, quer por razões financeiras ou por outras razões; sabe o que deveria fazer, e obviamente poderia fazê-lo, mas não quer fazer, certos valores e atitudes o retém, ou de outra forma, ele prefere seguir outro valor". Analisando esta colocação, por sua vez similar ao encontrado em nossa pesquisa, sugerimos que a população rural investigada é pouco informada sobre as questões ambientais, bem como, que as transformações dos usos da terra na Bacia vêm afetando tanto a sua identidade local, como as relações a respeito dos elementos naturais da paisagem agrícola, fazendo com que a população permaneça alheia às ações de conservação (COMIN et al., 2009). Foram comuns no presente estudo, relatos dos entrevistados a respeito do descumprimento da legislação ambiental por parte dos canavieiros, mineradores, que agem de forma mais agressiva em relação aos recursos hídricos. Para Martins (2007), “a territorialização das políticas públicas para a sustentabilidade em áreas rurais requer, dentre outros, a atenção para os arranjos das relações de poder que tencionam sobre as possibilidades de transformação da própria localidade".

Se, por um lado a população estudada permanece alheia às questões de conservação, por outro, tanto os gestores, como os pesquisadores não percebem que é a compreensão das diferentes percepções e representações sociais do ambiente a base para soluções dos problemas ambientais na APA do Corumbataí. Portanto, na conservação da biodiversidade em paisagens agrícolas, o agricultor familiar é elemento primordial, conforme concebido anteriormente como "espécie-guarda-chuva" em relação aos serviços ecossistêmicos relacionados à água ou mesmo da biodiversidade. Segundo Martins (2006), a construção local de estratégias de gestão dos recursos no território tende a refletir a conjuntura sócio-política da própria localidade. Dessa forma o autor sugere que sociedade local não está dissociada das 
estruturas locais de dominação política e que os sistemas de ideias, saberes, conhecimentos, percepções e da capacidade de inovação podem servir de alicerce para a construção de estratégias de governança dos recursos do território. Nesse sentido, tais populações devem ser vistas como um caminho para ajudar a conservação. Segundo Gliessman (2000), o processo de transição de paisagens alteradas para agroecossistemas mais sustentáveis é complexo e exige um redesenho dos componentes dos agroecossistemas, para que estes funcionem com base em um novo conjunto de processos sociais e ecológicos. É nesse sentido que trataremos a seguir, a questão da multifuncionalidade ambiental da agricultura familiar na APA Corumbataí.

A temática da multifuncionalidade da agricultura surge na França no século passado, e rompe com a lógica exclusivamente econômica por não se limitar à produção agrícola ou alimentar e focalizar os serviços ou as funções que a agricultura exerce como, por exemplo, a conservação do meio-ambiente (CARNEIRO, 2006). Nesta perspectiva, a multifuncionalidade da agricultura começa a ser associada à produção de bens públicos, em sua maioria com caráter não-mercantil. Nesse caso, a multifuncionalidade na agricultura não está apenas relacionada à sua função produtivista ou mercantil. Está mais relacionada às suas funções sociais e ambientais.

Maluf et al. (2009) dizem que a aplicação da multifuncionalidade para além das formas de agricultura familiar pode ser problemática. Mas se a noção de multifuncionalidade da agricultura familiar for voltada para as políticas públicas, pode promover modelos de produção mais equitativos, ambientalmente corretos e valorizando a sóciobiodiversidade em seus biomas (MALUF et. al, 2009, p. 10). É nesse sentido que a multifuncionalidade da agricultura parece se contrapor ao processo de individualização do homem, o que significa reaproximar a sociedade da natureza. Dessa maneira, o resultado de externalidades positivas geradas por determinados sistemas produtivos agropecuários beneficiariam a sociedade em geral (MARQUES; ALLES, 2008, p. 5).

Neste estudo as considerações sobre a multifuncionalidade da agricultura familiar na Bacia podem representar uma tentativa de reconhecer as unidades produtivas não apenas como produtoras de bens agrícolas ou sociais, mas também ligada a suas funções ambientais. Segundo Wanderley (2003, p. 09) ao romper com a hegemonia exclusiva da "função" econômica da propriedade rural, o enfoque multifuncional da unidade produtiva pode propiciar o entendimento do agricultor em suas complexas relações com a natureza. Sendo assim, neste estudo, a ênfase dada à multifuncionalidade da agricultura familiar e suas relações com o ambiente pode fortalecer a conservação dos recursos naturais. Em trabalho 
recente Martini e Trentini (2011), trazem que o conceito de multifuncionalidade da agricultura, quando aplicados aos recursos hídricos repercutem de forma positiva na sociedade, considerando ser indesatável a produção agrícola e a produção água. Rodrigues et al,. 2002, estudando agricultores na APA de Guaraqueçaba - PR, a questão central da conservação dos recursos naturais e principalmente hídricos está no desafio de implementar formas de gestão que garantam a continuidade dos serviços agrícolas no que tange a suas funções econômicas, sociais e ambientais. Para Benatti (2003), a propriedade agrícola tem a incumbência constitucional de produzir alimentos, matérias-primas e de proteger os bens ambientais. Portanto, a função social e ambiental da propriedade, se aproxima da multifuncionalidade ambiental da propriedade agrícola, efetivada quando os serviços ambientais do ecossistema estão assegurados e o desenvolvimento econômico das atividades agrárias mantém um grau satisfatório das funções ecológicas.

Portanto, o que este trabalho sugere é que, a partir dos dados obtidos, seja possível desenvolver um campo teórico sobre a multifuncionalidade ambiental da agricultura familiar em paisagens agrícolas, como forma de entendimento da dinâmica da população rural em relação à conservação da natureza.

Para sensibilizar e defender essa proposta recorreremos a Ferraz et al. (2009), que, por meio de indicadores de sensibilidade ambiental selecionaram 58 microbacias na Bacia do Corumbataí e sugerem que existe a necessidade de um reflorestamento criterioso nestas áreas. Partindo dos dados obtidos neste estudo, foi realizada uma relação com a proposta feita por Ferraz et al. (2009), onde constatamos que as propriedades visitadas estão inseridas ou próximas às microbacias selecionadas pelos autores supracitados como áreas prioritárias para restauração florestal (Figura 7). 


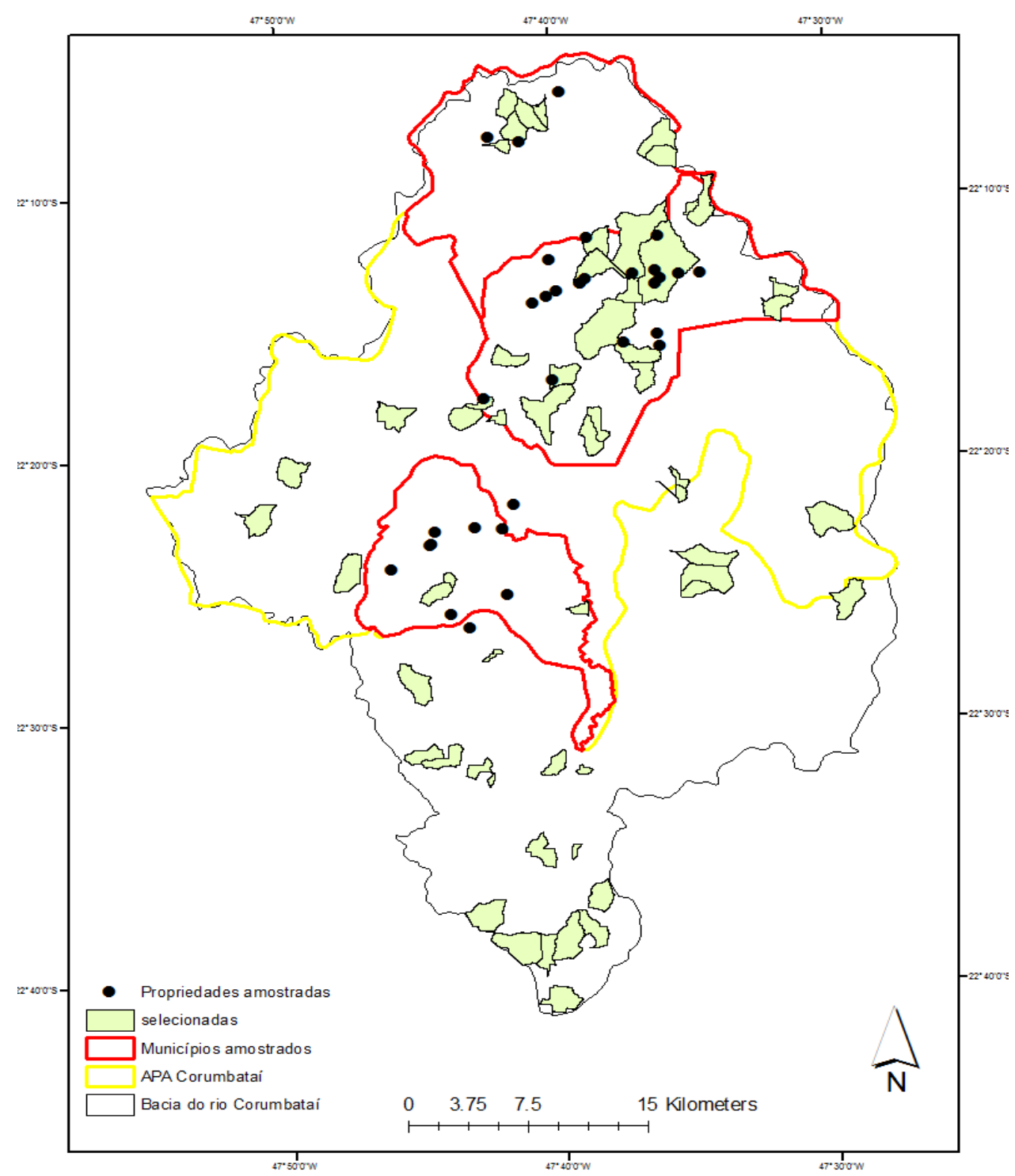

Figura 7 - Distribuição dos pontos de coleta sobrepostos ás microbacias consideradas prioritárias para restauração florestal proposto por Ferraz et al. (2009) (Figura adaptada)

A figura acima revela ao menos duas constatações: primeiro que as ações antrópicas, de modo geral, são responsáveis pela degradação ambiental; segundo que, por serem unidades pequenas, os agricultores familiares têm papel crucial nos processos de conservação ambiental. Algumas escolas de pensamento colocam a população humana como modificadora e degradadora do ambiente, outras defendem que pequenas sociedades são conservadoras do ambiente e ao mesmo tempo criadoras de biodiversidade (Samith; Wishine, 2000). Desse modo, sessenta por cento das unidades investigadas estão sobrepostas às áreas prioritárias e o restante delas está conectada através de nascentes e córregos, o que as torna da mesma forma 
prioritárias em quaisquer proposta de recuperação ou restauração da estrutura florestal do tipo mata-ciliar.

Partindo desta correlação e das características da multifuncionalidade da agricultura familiar e suas relações com o ambiente, este trabalho sugere a possibilidade de desenvolver um campo teórico sobre a multifuncionalidade ambiental da agricultura familiar em paisagens agrícolas. Algumas proposituras para que essa relação seja positiva podem vir de forma que os agricultores familiares participem dos processos e projetos de conservação, como por exemplo, restauração florestal ou adequação ambiental, nas unidades produtoras e mantenedoras de serviços ecossistêmicos. Ferraz et al. (2009), justificam a necessidade de um reflorestamento criterioso na região, já que a ausência da formação florestal tem gerado um desequilíbrio do regime hídrico, causando problemas na abastecimento de cidades como Piracicaba e Rio Claro. Segundo Brancalion et al. (2012), a produção de alimentos e restauração florestal não devem ser vistas como competidoras por áreas, mas um caminho para ajudar a aumentar a produção de alimento, melhorando a qualidade de vida e promovendo um retorno econômico ao proprietário da terra. Ferraz et al. (2009) comentam ainda que, devido às limitações dos recursos, é necessário que sejam realizados estudos de seleção de áreas, para que o ganho ambiental seja o máximo. Neste sentido, no caso da APA, nos projetos de restauração, a escolha das áreas deve priorizar os agricultores familiares residentes nas unidades produtivas, gerando assim contribuições na produção de alimento, madeira, produtos não madeireiros e serviços ecossistêmicos.

Atualmente, tramitam no congresso nacional propostas de Pagamentos por Serviços Ambientais que, por sua vez foi bastante lembrado pelos entrevistados e muitos se declararam favoráveis a esse instrumento. Outra proposta vem do Pacto da Mata Atlântica, que projeta a restauração de sete milhões de hectares de pastos degradados. Estudos apontam que, dez anos depois da implantação de modelos de restauração, as áreas restauradas tornam-se mais lucrativas que pastagens para gado (BRANCALION et al., 2012). Além disso, há outras formas de fomentar, contribuir e inserir os agricultores nas práticas conservacionistas, tal como as propostas agroecológicas e os sistemas agroflorestais, métodos técnico-científico reconhecidos e capazes de impulsionar uma mudança substancial e significativa no meio rural da APA (ALTIERI, 2001; CAPORAL, 2009).

É nesse sentido que entendemos como o diálogo interdisciplinar com a incorporação das dimensões humanas pode ser útil à conservação. No caso estudado, estamos propondo que no espaço rural da APA Corumbataí, a restauração ou recuperação das funções ambientais devem ser priorizadas nas propriedades pequenas que comportam a agricultura familiar, 
possibilitando uma aproximação do meio rural com o meio ambiente. Desse modo, a agricultura familiar, por não ser voltada para o mercado, é menos agressiva ao meio ambiente. Por si só, isso justifica que a base de recuperação, restauração ou conservação dos recursos ambientais na APA e na Bacia tem por obrigação o correr primeiramente em unidades produtivas da agricultura familiar residente. Com isso, as atividades rurais em termos de multifuncionalidade ambiental levariam a uma valorização das unidades produtivas do ponto de vista conservacionista. É isso que coloca a agricultura familiar da APA no contexto da conservação ambiental e das novas ruralidades.

Fitzgerald e Stronza (2009), afirmam que a compreensão socioambiental promove habilidades para responder à variedade de interesses sociais, científicos e políticos na conservação da natureza. A partir desta colocação e do ponto de vista técnico/científico da conservação da biodiversidade, no caso estudado, o público investigado desconhece a importância da sua parte na conservação dos recursos hídricos. Do mesmo modo, é relevante sua participação na produção, qualidade e manutenção as funções hidrológicas nas unidades produtivas, colocando-o no papel de produtor e conservador de água.

Os resultados que acabamos de discutir nos permitem refutar a hipótese testada que a relação entre as formas de uso da terra dos pequenos proprietários da APA Corumbataí com o ambiente não levam em conta a conservação dos recursos hídricos nem as áreas de preservação permanente e de reserva legal. Assim a melhor forma de enxergar essa relação seria que as práticas agrícolas e as formas de vida dos agricultores familiares da região são favoráveis à conservação da biodiversidade, já que esses agricultores podem ter um importante papel na conservação ambiental por manterem APPs e fragmentos de RL. Isto fica claro e evidente quando sobrepomos os dados do presente estudo e as áreas prioritárias para restauração florestal (FERRAZ, et al., 2009), mostrando particularmente inclusive a integração de métodos com os resultados deste estudo e com aos utilizados em sistemas de informação geográfica e sensoriamento remoto. Para Moram e Ostrom (2005) é esta correlação entre métodos que contribui para os desafios da gestão e ao mesmo tempo soluções dos problemas ambientais.

Os resultados sugerem que os fatores sociais, ambientais, políticos e históricos do uso e ocupação do solo afetaram o ambiente total, e nesses ambientes a agricultura familiar se adaptou e, portanto não devem ser deixadas em segundo plano (LISBOA, 2008). Assim, tão importante quanto o modelo proposto de "olhar para o todo" que fala de maneira subjacente às comunidades rurais na questão ambiental, é pertinentemente nessa discussão um novo 
modelo sob a proposta de olhar para o "outro" sob as perspectivas de conservação das paisagens agrícolas no estado de São Paulo.

Estudar o meio ambiente e meio rural é uma temática que ainda requer amadurecimento na Bacia. O que foi exposto neste estudo vem somar aos muitos esforços desenvolvidos na pesquisa mundial e que se encontram numa fase de transição de visão sistêmica dos problemas ambientais. No entanto, foi demonstrado que área estudada, os agricultores, familiares ou patronais, são partes integrantes do ecossistema e ao considerar este fato, novas oportunidades para o fortalecimento tanto da conservação ambiental, como das pesquisas em paisagens agrícolas, poderão emergir.

\subsection{Considerações Finais}

Devemos considerar inicialmente que os pensamentos sociológico rural e biológico conservacionista devem incorporar as dimensões humanas ao mundo natural, adotando a multifuncionalidade ambiental da paisagem agrícola como forma de aproximação das políticas desenvolvimentistas e conservacionistas na Bacia do Corumbataí.

A partir deste estudo, demonstramos que na paisagem agrícola estudada, os agricultores familiares investigados respeitam a APP e mantém as Reservas Legais, ou seja o morador, a seu modo, tem relação direta com a conservação. É este o princípio em que podemos nos basear na funcionalidade da paisagem agrícola ou da multifuncionalidade ambiental conforme sugerido neste estudo. Segundo Cullen Jr. (2000), o tipo de vizinhança e uso da terra podem afetar profundamente a diversidade biológica, os processos ecológicos e a conservação. Por isso, se ninguém tentar entender como se dá esta relação, ou mesmo entender como é possível envolvê-lo na conservação, qualquer proposta ou pesquisa ou política conservacionista está fadada ao fracasso.

Ao trazer a agricultura familiar para a esfera da conservação ambiental reconhecemos que na paisagem agrícola socialmente ocupada, este grupo tem ligações claras com os serviços ecossistêmicos e sua conservação. Se por um lado, pesquisas sobre conservação ambiental em paisagem agrícola e as políticas ambientais sobre a gestão dos recursos naturais privilegiam a preservação e recuperação de vegetação nativa, seja por suas funções ecológicas ou ainda, pela manutenção da estabilidade dos ciclos hidrológicos e biogeoquímicos por estes darem as condições necessárias para a agricultura. Por outro, e da mesma forma, as pesquisas e as políticas públicas ambientais deverão encontrar mecanismos eficientes de inclusão da 
agricultura familiar nas questões de conservação em paisagens agrícolas, uma vez que este grupo representa 66\% dos estabelecimentos rurais do estado de São Paulo.

Tanto os órgãos municipais ambientais e agrícolas, como os gestores da APA e da CBH-PCJ devem olhar para o agricultor familiar residente na região e fomentar sem nenhum ônus todos os mecanismos necessários para a adequação ambiental da propriedade rural, considerando-o como produtor de água. Deverá ainda promover e incorporar mecanismos de aproveitamento econômico por meio de exploração de espécies madeireiras, medicinais, frutíferas nativas e melíferas que, de certo modo, proporcionarão o desenvolvimento econômico e a manutenção do homem no campo. No entanto, para que isso ocorra é necessária à efetiva presença do Estado no meio rural por meio de um serviço eficiente de extensão rural. Da mesma forma, os pesquisadores que atuam na Bacia devem promover a extensão universitária, fazendo com que os resultados das pesquisas cheguem até a população, divulgando esses resultados de forma clara e acessível. Uma alternativa é a promoção de eventos para que se discuta de diferentes perspectivas, a situação socioambiental local, e deve ser promovido por aqueles que realizam pesquisas nestas áreas, na tentativa de gerar propostas integradas para gestão e práticas da conservação. Estes encontros teriam como resultado documentos norteadores de políticas públicas locais, aproximando assim, a pesquisa, a população, a governança e os propósitos comuns para conservação socioambiental, bem como, o fortalecimento da agricultura familiar na APA.

As Áreas de Proteção Ambiental são espaços ideais para pesquisas de cunho conservacionista ou mesmo aqueles que atuam na temática da "sustentabilidade" ou de desenvolvimento sustentável. Estas áreas favorecem a implantação de pesquisas de longa duração, específicas ou interdisciplinares, por apresentarem no mesmo espaço propósitos de estudos entre sociedade e natureza. Neste estudo, a discussão sobre participação dos agricultores familiares na conservação ambiental ganhou corpo e parece que não deve ser tratada como questão de pouco interesse. Essa nova temática deve passar a ser objeto de pesquisa se a preocupação com o ambiente for objetivo da conservação na APA e seus recursos, principalmente os hídricos. 


\section{Referências}

ABRAMOVAY, R. O futuro das regiões rurais. Porto Alegre: Editora da UFRGS, 2003. $150 \mathrm{p}$.

ALBUQUERQUE, U.P. introdução a etnobotânica. Recife: Bagaço, 2002. 87 p.

ALMEIDA, A. W. B. de. Terra de preto, terra de santo, terra de índio: uso comum e conflito. Humanidades: Rio de Janeiro, p.15, 1988.

ALMEIDA, J. Da ideologia do progresso à ideia de desenvolvimento (rural) sustentável. Educação Agrícola Superior, Brasília, v. 15, n. Especial, p. 51-85, 1997.

ALTIERI, M.A. Agroecologia: a dinâmica produtiva da agricultura sustentável. 3. ed. Porto Alegre: UFRGS, 2001. 110p. (Síntese Universitária, 54).

ALTIERI, M.A. Linking ecologists and traditional farmers in the search for sustainable agriculture. Front. Ecol. Environ., v. 2, n. 1, p. 35-42, 2004.

ALVES, E., SILVA e SOUZA, G., BRANDÃO, A. S.P. A situação do produtor com menos de 100 hectares. Revista de Política Agrícola. n.4, p. 27-36, 2006.

AMOROZO, M. C. M. Abordagem etnobotânica na pesquisa de plantas medicinais. In L.C.Di Staci (org). Plantas Medicinais: arte e ciência-um guia de estudo interdisciplinar. São Paulo, Editora da Universidade Estadual Paulista. 1996 713p.

ANTONIAZZI, L.B. Oferta de serviços ambientais na agricultura. 2008. 91p. Dissertação (Mestrado em Economia Aplicada) - Escola Superior de agricultura "Luiz de Queiroz", Universidade de São Paulo, Piracicaba, 2008.

BALÉE, W. The research program of historical ecology. Annual Review of Anthropology, Palo Alto, v. 35, p 75-98, 2006.

BARTHÉLÉMY, D. La multifonctionnalité agricole comme relation entre fonctions marchandes et non marcahndes. Les Cahiers de la multifonctionnalité, v. 2, p. 95-99, 2003.

BEGON, M.; TOWNSEND, C.R.; HARPER, J.L. Ecologia de indivíduos a ecossistemas. 4. ed. Porto Alegre: Artmed Editora,2007. 686p.

BENATTI, J.H. (2003). Direito de Propriedade e Proteção Ambiental no Brasil: apropriação e uso dos recursos naturais no imóvel rural. Tese de Doutorado. NAEA/UFPA. Belém/PA.

BERKES, F., COLDING, J. , FOLKE, C. Navigating Social-Ecological Systems: Building Resilience for Complexity and Change. Cambridge Univ. Press: Cambridge, UK, 2003. 393 p.

BERNARDI, B. Introdução aos estudos etno-antropológicos. Ed. Milão: 1974. 450p.

BLUMENTAL, D.,JANNINK, J. L. A classification of collaborative management methods. Conservation Biology, V. 4, n.2, p.13 2000. 
BONNAL, P. ; PIRAUX M, ; FUSILLIER J.L.; GUILLUY D. Approche de la multifonctionnalité de l'agriculture à la Réunion: les modèles agricoles, la relation agriculture-emploi et la perception des CTE par les acteurs locaux. MAAPAR et CIRAD: Paris, 2003. 68p.

BONNAL, P., MALUF, R. S. Políticas de desenvolvimento territorial e multifuncionalidade da agricultura familiar no Brasil. Política e Sociedade, v. 14, p. 211-250, 2009.

BRANCALION, P.H.S.; VIANI, R.A.G.; STRASSBURG, B.B.N.; RODRIGUES, R.R. Finding the money for tropical forest restoration. Unasylva, New York, v. 63, p. 41-50, 2012.

CAMPANHOLA, C.; SILVA, J.G. O Novo Rural Brasileiro: uma análise nacional e regional. Jaguariúna: Embrapa Meio Ambiente, 2000. 190p.

CANDIDO, A. Os parceiros do Rio Bonito: estudo sobre o caipira paulista e a transformação dos seus meios de vida. 34.ed. São Paulo: Duas Cidades, 2001. 376p.

CAPORAL, F.R. Agroecologia: uma nova ciência para apoiar a transição a agriculturas mais sustentáveis. Brasília: Imprenta, 2009. 30p.

CARMASSI, A.L.; RONDINELI, G.; FERREIRA, F.C.; BRAGA, F.M.S. Composition and structure of assemblage from Passa Cinco stream, Corumbatai river sub-basin, SP, Brazil. Brazilian Journal of Biology, São Carlos, v. 72, n. 1, p. 87-96, 2012.

CARMO, R.B.A. A Questão Agrária e o Perfil da Agricultura Brasileira. Disponível em: http://www.cria.org.br/gip/gipaf/itens/pub/sober. Acesso em: 10 maio 2010.

CARNEIRO, M.J. Pluriatividade da agricultura no Brasil: uma reflexão crítica. In:

SCHNEIDER, S. (Coord.). A diversidade da agricultura familiar. Porto Alegre: Editora da UFRGS, 2006. p. 165-185.( Série Estudos Rurais).

CARNEIRO, M.J.; GUEDES-BRUNI, R.; LEITE, S. Conhecimento científico e políticas públicas: mobilização e apropriação do saber em medidas de conservação da Mata Atlântica. Estudos Sociedade e Agricultura, Rio de Janeiro, v.17, n. 2, p. 254-303, 2009.

CAZELLA, A. A., MATTEI , L. Multifuncionalidade agrícola e pluriatividade das famílias de agricultores : novas bases interpretativas para repensar o desenvolvimento rural, in IV Congresso SBS-IESA, Santa Catarina, maio de 2002, 22p.

CHAMBERS, R. The origens and practice of participatory rural appraisal. Word Development, v. 22, t. 953-969. 1994.

COLCHESTER, M. Resgatando a natureza: comunidades tradicionais e áreas protegidas. In DIEGUES, A.C. (org.) Etnoconservação: novos rumos para a proteção da natureza nos trópicos. Hucitec: São Paulo, 2000.

COMIN, F.H; GARAVELLO, M.E.P.E; GHELER-COSTA, C. Meio Rural da Bacia Hidrográfica do Corumbataí: interdisciplinaridade, uso e conservação. In: SEMINÁRIO 
INTERNACIONAL RURALIDADES, TRABALHO E MEIO AMBIENTE,1., 2011, São

Carlos. Anais... São Carlos: Editora da UFSCar, 2011. p. 33.

COMIN, F.H; GHELER-COSTA, C; VERDADE, L; GARAVELLO, M.E.P.E. Relações e conflitos na conservação ambiental da bacia do Rio Passa-Cinco - São Paulo - Brasil.

OLAM Ciência e Tecnologia, Rio Claro, v. 9, n. 2, p. 254-258, 2009.

COMPANHIA DE TECNOLOGIA DE SANEAMENTO DO MEIO AMBIENTE - CETESB. Relatório de Qualidade das águas interiores no Estado de São Paulo 2008. São Paulo, 2009. Disponível em: HTTP://www.cetesb.sp.gov.br/Agua/Rios/publicacoes.asp. html Acesso em: 10 maio 2010.

CONVENÇÃO SOBRE DIVERSIDADE BIOLÓGICA - CDB. Ministério do Meio Ambiente - MMA. Texto sobre a Convenção sobre Diversidade Biológica. Decreto Federal 2519/1998. Disponível em: www.mma.gov.br/estruturas/sbf_dpg/_arquivos/cdbport.pdf. Acesso em: 10 maio 2010.

CULLEN JUNIOR, L.; BODMER, R.E. ; PADUA, C.V. Effects of hunting in habitat fragments of the Atlantic Forests, Brazil. Biological Conservation, Boston, v. 95, p. 49-56, 2000.

DE LUCAS, A.; MORUZZI MARQUES, P.E. ; SARMENTO, G. Trajetórias da agricultura familiar e o papel da extensão rural: estudo do caso do alto da serra de São Pedro/SP. In: CONGRESO LATINOAMERICANO DE SOCIOLOGÍA RURAL, 8., 2010, Ipojuca/PE. Anales... América Latina: realinhamentos políticos y proyectos en disputa, 2010.p?????

DEAN, W. Rio Claro: um sistema brasileiro de grande lavoura - 1820-1920. Rio de Janeiro: Paz e Terra, 1977. 205p.

DIEGUES, A.C. O mito moderno da natureza intocada. Hucitec: São Paulo, 1996.

DINIZ-FILHO, J.A.F.; BINI, L.M.; OLIVEIRA, G.; BARRETO, B.S.; SILVA, M.M.F.P.; TERRIBILE, L.C. Macroecologia, biogeografia e áreas prioritárias para conservação no cerrado. Oecologia Brasiliensis, Rio de Janeiro, v. 13, n. 3, p. 470-497, 2009.

DOTTA, G .; V ERDADE, L.M. Felids in an agricultural landscape in São Paulo Brazil. Cat News, London, v. 51 ,2009.

DOTTA, G. ; VERDADE, L.M. Trophic categories in a mammal assemblage: diversity in an agricultural landscape. Biota Neotropica, São Pailo, v.7, n. 2, p. 287-292, 2007.

DOTTA, G.; VERDADE, L.M. Medium to large-sized mammals in agricultural landscapes of South-eastern Brazil. Mammalia, Paris, v. 75, p. 345-352, 2011.

DOUGLAS, M. Purity and Danger. London: Routledge and Kegan Paul, 1969.

EXTREMA. Lei Municipal $\mathrm{n}^{\mathrm{o}}$ 2.100, de 21 de dezembro de 2005. "Cria o Projeto Conservador das Águas, autoriza o executivo a prestar apoio financeiro aos proprietários rurais e da outras providencias". Prefeitura Municipal de Extrema, Minas Gerais, 2p. Disponível em: 
http://www.ana.gov.br/Produagua/LinkClick.aspx?fileticket=NJ5kOf5ilHw\%3D\&tabid=698 $\underline{\& \operatorname{mid}=1510}$

FAO Multiples fonctions de l'agriculture et des terres: l'analyse. FAO, Maastricht, 1999.

FERRAZ, S.F.D.; PAULA, F.R.; VETTORAZZI, C.A. Incorporation sustainability indicators on site selection for Forest restoration in the Corumbatai River basin. Revista Árvore, Viçosa, v. 33, n. 5, p. 937-947, 2009.

FERREIRA, L.C. Dimensões Humanas da Biodiversidade: mudanças socais e conflitos em torno de áreas protegidas no Vale do Ribeira, SP, Brasil. Ambiente e Sociedade, Campinas, v. 7, p. 47-86, 2004.

FISCHLER, C. "Food, Self and Identity" In: Social Sciences Information, V. 27, n.2. p. 92275. 1988.

FITZGERALD, L.A; STRONZA, L.A. Applied Biodiversity Science: bridging Ecology, Culture, and Governance for Effective Conservation. Interciencia, Caracas, v. 34, n.8, p. 99$110,2009$.

FRANÇA, C.G.; DEL GROSSI, M.E.; MARQUES, V.P.M.A. O Censo Agropecuário 2006 e a agricultura familiar no Brasil. Brasília: MDA, 2009. Disponível em:

<http://www.mineiropt.com.br/arquivosestudo/arq4b10179787f8b.pdf> Acesso em: 22 dez. 2009.

FREIXEDAS, V. Reflexões sobre conservação e diálogo. In: FALEIROS, K.; PASTOR, C. G. De olho na bacia: material didático de educação ambiental para a Bacia do Ribeirão Piracicamirim. Piracicaba: Instituto Terra Mater, 2012. 104p.

FUINI, L.L. Estudo do mercado de trabalho em arranjo produtivo local (APL): território e produção de cerâmica em Santa Gertrudes, SP. Sociedade e Natureza, v. 20, p.75-85, 2008.

GALIZONI, F.M. A terra construída. Dissertação (mestrado), FFLCH-USP, 2000.

GALJART, B. Difusão cultural, modernização e desenvolvimento. In: SZMRECSAMYI, T.; QUEDA, O. (Org.). Vida rural e mudança social. 3. ed. São Paulo: Ed. Nacional, 1979. p. 57-65.

GARAY, I,G; BECKER, B,K. As Dimensões Humanas da Biodiversidade. O desafio das novas relações sociedade-natureza no século XXI. Petrópolis: Vozes, 2006. 483p.

GARCIA, L.B.R. Ocupação e desenvolvimento econômico em função da paisagem da bacia do Rio Corumbataí: séculos XVII a XX: atlas ambiental da bacia do Rio Corumbataí (2000). Disponível em: <http://www.re.unesp.br/igce/cealp. html>. Acesso em: 16 jul. 2005.

GEERTZ, C. O saber local: novos ensaios em antropologia interpretativa. Petrópolis: Vozes, 2000. 366p.

GEHLEN, I. Políticas públicas e desenvolvimento social rural. São Paulo em Perspectiva, v.18, n.2, p. 95-103, 2004. 
GHELER-COSTA, C.; VETTORAZZI, C.A.; PARDINI, R.; VERDADE, L.M. The distribution and abundance of small mammals in agroecosystems od southeastern Brazil. Mammalia, Paris, v.76, p.185 - 191, 2012.

GLIESSMAN, S.R. Agroecologia: processos ecológicos em agricultura sustentável. 2. ed. Porto Alegre: Editora da Universidade, 2000. 653p.

GOMES, G.A. Práticas, preceitos e problemas associados à escassez da água no vale do Jequitinhonha, Minas Gerais. Anais / XII Encontro Nacional de Estudos Populacionais da ABEP. Caxambu, 2000.

GONÇALVES, J.S.; SOUZA, S.A.M. Agricultura familiar: limites do conceito e evolução do crédito. Instituto de Economia Agrícola. Disponível em:

$<$ http://www.iea.sp.gov.br/out/verTexto.php?codTexto=2521>. Acesso em: 25 jul.2005.

GRAZIANO SILVA, J. O novo rural brasileiro. Revista Nova Economia, Belo Horizonte, v.7, n. 5, 90p. 1997

GUANZIROLI, C. E.; BUAINAIM, A. M. ; DISABBATO, A. . Dez Anos de Evolução da Agricultura Familiar no Brasil: (1996 e 2006). Revista de Economia e Sociologia Rural (Impresso), v. 50, p. 351-370, 2012.

GUANZIROLI, C.; CARDIM, S.E. (Coord.). Novo retrato da agricultura familiar: O Brasil redescoberto. Brasília: Projeto de Cooperação Técnica FAO/INCRA, 2000. 74 p. Disponível em: http://www.incra.gov.br/fao/pub3.html. Acesso em: 23 mar. 2005.

GUILHOTO, J. J. M.; SILVEIRA, F. G.; AZZONI, C. PIB das cadeias produtivas da agricultura familiar. São Paulo: FIPE/NEAD/MDA, 2004.

HOMMA, A. K. O. Eixo Tecnológico da Ecorregião Norte: Agricultura familiar na Amazônia- a modernização da agricultura etinerante. In: SOUSA, I. S. F. (Org.) Agricultura familiar na dinâmica da pesquisa agropecuária. Brasília, DF.: Embrapa Informação Tecnológica, 2006.

HURTIENNE, T. Agricultura familiar na Amazônia Oriental uma comparação dos resultados da pesquisa socioeconômica sobre fronteiras agrárias sob condições históricas e agroecológicas diversas. Novos Cadernos, v. 2, n. 1, p. 75-94, 1999.

IMPRENSSA OFICIAL DO ESTADO DE SÃO PAULO (IMESP). São Paulo, v. 115, n. 129, 2005. Disponível em: http://www.imprenssaoficial.com.br.html. Acesso em: 12 jul.2005.

INSTITUO DE PESQUISAS E ESTUDO FLORESTAIS - IPEF. Plano Diretor: Conservação dos recursos hídricos por meio da recuperação e da conservação da cobertura florestal da bacia do Rio Corumbataí. Piracicaba: Vitor's Design, 2001. p300

INSTITUTO BRASILEIRO DE GEOGRAFIA E ESTATÍSTICA (IBGE). Censo Demográfico Brasileiro 2010. Disponível em: http://www.censo2010.ibge.gov.br. html. Acesso em: 10 ago. 2011. 
INSTITUTO DE ECONOMIA AGRÍCOLA - IEA. Banco de dados Projeto LUPA 1996/97 e 2007/08. Disponível em: http://www.iea.sp.gov.br/out/banco/menu.php.html Acesso em: 04 out. 2009.

INSTITUTO NACIONAL DE COLONIZAÇÃO E REFORMA AGRÁRIA (INCRA). Sistema Nacional de Cadastro Rural. 2007. Disponível em:< www.incra.gov.br/index.php/estrutura-fundiaria/indices-cadastrais.html Acesso em: 20 set. 2009.

INSTITUTO NACIONAL DE COLONIZAÇÃO E REFORMA AGRÁRIA (INCRA/FAO). Guia metodológico - análise-diagnóstico de sistemas agrários. Brasília: Incra/FAO, 2010. Disponível em: http://www.redeagroecologia.cnptia.embrapa.br/biblioteca/manuais-eguia.html Acesso em: 05 jan.2010

JACCOUD, M.; MAYER, R. A observação direta e a pesquisa qualitative. In: POUPART, J. et al. A Pesquisa Qualitativa. Enfoques epistemológicos e metodológicos. Petrópolis: Vozes, 2008. 464p.

JACOBSON, S.K.; McDUFF, M.D. Training idiot savants: the lack of human dimensions in conservation biology. Conservation Biology, Boston,v. 12, n. 2, p. 263-267, 1998.

JARDIM, G.M.; ARMAS, E.D.; MONTEIRO, R.T.R. Ecotoxicological assessment of water and sediment of the Corumbataí River, SP, Brazil. Brazilian Journal of Biology, v.68, n.1, p.51-59, 2008.

JOLY, C.A. ; RODRIGUES, R.R. ; METZGER, J.P. ; HADDAD, C.F.B. ; VERDADE, L.M. ; OLIVEIRA, M.C. ; BOLZANI, V.S. Biodiversity Conservation Research, Training, and Policy in So Paulo. Science, Washington, v. 328, p. 1358-1359, 2010.

KAGEYAMA, A. Os rurais e os Agrícolas de São Paulo no Censo de 2000. Cadernos de Ciências \& Tecnologias, Brasília, v. 20, n. 3, p. 413-451, set/dez. 2003.

KREBS, C.J. Ecology: The Experimental Analysis of Distribution and Abundance. $5^{\text {th }}$ ed. California: Benjamin Cummings, 2001. 801 p.

LAMARCHE, H. A agricultura familiar: Comparação internacional. Uma realidade multiforme. Campinas: Editora da UNICAMP, 1993. 336p.

LAURENT, C. Activité agricole, multifonctionnalité et Pluriactivité. In: Pour. n. 64, p. 41, dec. 1999.

LISBOA, M.A. A politica dos coronéis e a difusão do ensino primário em Angatuba/SP (1870-1930). 2008. 408p. Tese (Doutorado em Educação) - Faculdade de Educação, Universidade de Campinas, Campinas, 2008.

LIU, J. et al. Complexity of Coupled Human and Natural Systems. Science, v. 317, p. 15131516. 2007. 
MALUF, R. A multifuncionalidade da agricultura na realidade rural brasileira. In:

CARNEIRO, M. J.; MALUF, R. (Org.). Para além da produção: multifuncionalidade e agricultura familiar. Rio de Janeiro: Mauad, 2003. p. 135-152.

MALUF, R. S. O enfoque da multifuncionalidade da agricultura: aspectos analíticos e questões de pesquisa in Lima, D.M. e Wilkinson, J. (orgs.). Inovação nas tradições da agricultura familiar. Brasília, CNPq/Paralelo 15, 2002, 301-328.

MALUF, R.S.; CAZELLA, A.A.; BONNAL, P. (Coord.). Agricultura Familiar:

Multifuncionalidade e desenvolvimento territorial no Brasil. Rio de Janeiro: Mauad, 2009. 304p.

MAMED-COSTA, A.C.; PERONI, L.F.; GASPAR, D.A.; GOBBI, N. Diagnóstico da mastofauna da bacia do Corumbataí, Estado de São Paulo, Brasil. Brazilian Journal of Ecology, São Paulo, n. 1/2, p. 29 - 35, 2000.

MARINO, E. Jr. Análise integrada dos efeitos do uso da terra em fragmentos florestais da bacia do rio Corumbataí. 2006. 111 p. Tese (Doutorado em Ecologia de Agroecossistemas) Escola Superior de Agricultura "Luiz de Queiroz", Universidade de São Paulo, Piracicaba, 2006.

MARQUES, P.E.M.; ALLES, J.M. Debate sobre as funções sócio-ambientais da propriedade fundiária e a noção da Multifuncionalidade da Agricultura. In: CONGRESSO DA SOCIEDADE BRASILEIRA DE ECONOMIA, ADMINISTRAÇÃO E SOCIOLOGIA RURAL, 46., 2008, Rio Branco. Disponível em:

http://www.sober.org.br/palestra/9/367.pdf.html. Acesso em: 19 set. 2011.

MARTINELLI, L.A., FILOSO, S. Expansion of sugarcane ethanol production in Brazil: Environmental and Social Challenges. Ecological Applications, Washington, v. 18, p. 885898, 2008.

MARTINI, L.C.P, TRENTINI, E.C. Agricultura em zonas ripárias do sul do Brasil: conflitos de uso da terra e impactos nos recursos hídricos. Revista Sociedade e Estado, v. 26, n. 3, p. 613-630, 2011.

MARTINS, R.C. Representações sociais, instituições e conflitos na gestão de águas em territórios rurais. Sociologias, Curitiba, v. 8, n. 5, p. 288 - 325, 2006.

MARTINS, R.C. Ruralidade e regulação ambiental: notas para um debate políticoinstitucional. Revista de Economia e Sociologia Rural, Brasília, v. 43, n. 2, p. 249-266, 2005 .

MINISTÉRIO DO DESENVOLVIMENTO AGRÁRIO - MDA. Programa Nacional de Agricultura Familiar. Disponível em:

http://www.mda.gov.br/portal/saf/programas/pronaf.html Acesso em: 04 out. 2009.

MORAIS, E.B.; TAUK-TRONISIELO, S.M.; VENTORINI, S.E. Impacto de atividades agropecuárias na qualidade das águas do rio Cabeça, na bacia do Rio Corumbataí, SP. Holos Environment, Rio Claro, v. 12, n. 1, p. 125-163, 2012. 
MORAN, E.F. Meio ambiente e ciências sociais: interações homem-ambiente e sustemtabilidae. São Paulo: Editora SENA, 2011. 307p.

MORAN, E.F.; PACKER, A; BRONDIZIO, E.S.; TUCKER, J. Restoration of Vegetation Cover in the Eastern Amazon. Ecological Economics, v.18, p. 41-54, 1996.

NOBRE, M.F. O zoneamento ecológico-econômico como instrumento de planejamento e gestão ambiental: uma proposta para a bacia hidrográfica do rio Corumbataí. 2008. 249p. Tese (Doutorado em Geociências) - Instituto de Geociências e Ciências Exatas, Universidade Estadual Paulista "Júlio de Mesquita Filho", Rio Claro, 2008.

OLIVEIRA, L.R., ALTAFIN, I.G. PROAMBIENTE: uma política de pagamento de serviços ambientais no Brasil. In: XLVI Congresso da Sociedade Brasileira de Economia, Administração e Sociologia Rural, 2008. Anais eletrônicos. Rio Branco, AC. 21p. Disponível em: www.ageconsearch.umn.edu

PALMA-SILVA, G.M.; TAUK-TORNISIELO, S.M.; PIÃO, A.C. Capacidade de autodepuração de um trecho do rio Corumbataí, SP, Brasil. Holos Environment, Rio Claro,v.7, n.2, p.139-153, 2007.

PERFECTO, I.; VANDERMEER, J.; WRIGHT, A. Nature's Matrix: Linking Agriculture, Conservation and Food Sovereignty. London: Earthscan, 2009. 242p.

PORTUGAL, Duque Alberto. O desafio da agricultura familiar. 2004. Disponível em < http://www.embrapa.br/imprensa/artigos/2002/artigo.2004-12-07.2590963189/ >. Acesso em 20 de nov. 20010.

RIBEIRO, E.M.; GALIZONI, F.M.; DANIEL, L.O.; AYRES, E.C.B.; ROCHA, L.C.D.;

RIBEIRO, M.C.; METZGER, J.P.; MARTENSEN, A.C.; PONZONI, F.J.; HIROTA, M.M. The Brazilian Atlantic Forest: How much is left, and how is the remaining forest distributed? Implications for conservation. Biological Conservation, Boston, v. 142, p. 1141-1153, 2009.

RODRIGUES, A., TOMMASINO, H., FOLADORI, G., GREGORCZUK, A. É correto pensar a sustentabilidade em nível local? Uma análise metodológica de um estudo de caso em uma Área de Proteção Ambiental no litoral sul do Brasil. Ambiente \& Sociedade, v. 5, n. 2, p. 109-127, 2002.

RODRIGUES, R.R.; BONONI, V.L.R. (Org.). Diretrizes para a conservação e restauração da biodiversidade no Estado de São Paulo.São Paulo: Imprensa Oficial do Estado de São Paulo, 2008. 238p.

RODRÍGUEZ, J. M., SÁENZ, A. Pago por servicios ambientales en Costa Rica: Un instrumento financiero para aumentar la competitividad Del sector forestal. Revista Forestal CentroAmericana, v. 3, p.68-71, 2002.

RODRÍGUEZ, J.M.; SÁENZ, A. Pago por servicios ambientales en Costa Rica - Un instrumento financiero para aumentar la competitividad del sector forestal. Revista Florestal CentroAmericana, p. 68-71, 2002. 
ROSA, H.; KANDEL, S.; SOTO, M.A.C.; GATJENS, V.R.; QUIRÓS, M.M.; BONILLA, O.S.; DIMAS, L. Gestión Local y Participación en torno al Pago por Servicios Ambientales: Estudios de Caso en Costa Rica. Artigo elaborado durante o projeto "Pago por Servicios Ambientales: Estudios de caso en Costa Rica", coordenado pelo PRISMA e patrocinado pela Fundação Ford, 2003, 72p.

SABOURIN, E. Multifuncionalidade da agricultura e manejo de recursos naturais: alternativas a partir do caso do semi-árido brasileiro. Tempo da Ciência, v.15, p. 9-27, 2008. SAHLINS, M. Culture and pratical reason. Chicago: The University of Chigago Press, 1976.

SAMITH, E.A.; WISHINE, M. Conservation and subsistence in small scale societies. Annual Review of Anthropology, Palo Alto, v. 29, p. 493-524, 2000.

SANTOS, B.S. Um discurso sobre as ciências. São Paulo: Cortez, 2006. 92p.

SÃO PAULO. Decreto Estadual n 20960 de 08 de junho de 1983. Diário Oficial, v. 96, n. $002,1983$.

SCHNEIDER, Sergio. A pluriatividade como estratégia de reprodução social da agricultura familiar no Sul do Brasil. Estudos Sociedade e Agricultura, Rio de Janeiro, v. 16, p. 164$184,2001$.

SEADE - FUNDAÇÃO SISTEMA ESTADUAL DE ANÁLISE DE DADOS. Secretaria de Planejamento e Desenvolvimento Regional. Dados estimados do Estado de São Paulo. 2010. Disponível em: http://www.seade.gov.br.html. Acesso em: 30 jun. 2011.

SILVA, D.L.; CUNHA, C.M.L. Análise morfométrica da bacia do córrego do Lajeado (SP). Caminhos de Geografia, Uberlândia, v.9, n.26, p.153-172, 2008.

SILVA, O.H. Agricultura Familiar: comparação internacional. Revista de Sociologia e Política, Curitiba, n.12 p. 161-216, 1999.

SILVEIRA, H.L.F.; VETTORAZZI, C.A.; VALENTE, R.O. Avaliação Multicriterial no mapeamento de risco de incêndios florestais, em ambiente SIG na Bacia do Rio Corumbataí, São Paulo. Revista Árvore, Viçosa, v. 32, n. 2, p. 259 - 268, 2008.

SOULÉ, M. What is conservation biology? BioScience, Washington, v. 35, p. 727-734, 1985.

THOMAS, K. O homem e o mundo natural. Companhia das Letras, 2010, 504p.

VALENTE, R.O.A. Análise da estrutura da paisagem na bacia do Rio Corumbataí, SP. 2001. 201p. Dissertação (Mestrado em Recursos Florestais) - Escola Superior de Agricultura "Luiz de Queiroz”, Universidade de São Paulo, Piracicaba, 2001.

VALENTE, R.O.A; VETTORAZZI, C.A. Mapeamento de uso e cobertura do solo na bacia do rio Corumbataí, SP. Circular Técnica IPEF, Piracicaba, n. 196, p. 10, 2003.

VEIGA, J. E. Agricultura familiar e sustentabilidade. Cadernos de Ciência \& Tecnologia, Brasília, v.13, n.3, p.383-404, 1996. 
VEIGA, J.E. Cidades imaginárias: o Brasil é menos urbano do que se imagina. 2. ed. Campinas: Ed. Autores Associados, 2003. 112p.

VEIGA, J.E. O Brasil rural precisa de uma estratégia de desenvolvimento. Brasília: NEAD, 2001.p 108 ( Texto para Discussão,01).

VERDADE, L.M. A exploração da fauna silvestre no Brasil: jacarés, sistemas e recursos humanos. Biota Neotropica, São Paulo, v. 4, n. 2, p. 5-17, 2004.

VIEIRA, P.F. Gestão dos Recursos Comuns para o Ecodesenvolvimento. In: VIEIRA, P,F; BERKES, F.; SEIXAS, C.S. (Ed.) Gestão Integrativa e participativa de recursos naturais: conceitos, métodos e experiências. Florianópolis: Secco/APED, 2005. 415p.

VIERTLER, R. B. Contribuições da antropologia para pesquisa em etnobioloiga. In: KUBO, R. R. (org.) Atualidades em Etnobiologia e Etnoecologia. Recife: NUPEA/SBEE, 2006, $284 p$.

WANDERLEY, M.N. Prefácio. In: CARNEIRO, M.J.; MALUF, R. (Org.) Para além da produção: multifuncionalidade e agricultura familiar. Rio de Janeiro: Mauad, 2003. p. 9-16.

YOUNÉS, T. Ciência da Biodiversidade: questões e desafios. In: Conservação da Biodiversidqde em Ecossistemas Tropicais. Petrópolis: Vozes, 2001. 427p.

YOUNÉS, T.; GARAY, I. As Dimensões Humanas da Biodiversidade. O desafio das novas relações sociedade-natureza no século XXI. Petrópolis: Vozes, 2006. 483p.

ZUQUETTE, L.V.; PALMA, J.B.; PEJON, O.J. Methodology to assess ground water pollution conditions (current and pré-disposition) in the São Carlos and Ribeirão Preto regions, Brazil. Bulletin Engineering Geology and the Environment, Nottinghan, v. 68, p. 11-136, 2009. 


\title{
4 PERSPECTIVAS INTERDISCIPLINARES PARA CONSERVAÇÃO DE PAISAGENS AGRÍCOLAS NO ESTADO DE SÃO PAULO
}

\section{Resumo}

A temática interdisciplinar no Brasil é recente, ainda em construção e requer um contínuo processo de amadurecimento intelectual. A proposta deste estudo é refletir sobre o modelo de conservação ambiental em paisagens agrícolas partindo de um modelo de pesquisa de conteúdo interdisciplinar, considerando-o como essencial para compreender o futuro dessa linha da pesquisa em paisagens agrícolas. O estudo trás algumas considerações de posicionamento crítico no sentido epistemológico da palavra para o entendimento do objeto sociedade/natureza ou ambiente/sociedade com vista à conservação da biodiversidade. $\mathrm{O}$ presente estudo, com base no processo interdisciplinar, trás a tona o diálogo de saberes partindo dos fundamentos teóricos da produção de conhecimento disciplinar. Ou seja, foi além dos enfoques unicamente disciplinares e articulou um diálogo cooperativo entre as ciências sociais e naturais. Por fim lança alguns desafios para o que chamamos de aliança cultural interdisciplinar e sugere que haja uma interligação de conhecimentos, de saberes, de práticas e ações extensionista para conservação ambiental na Bacia do Corumbataí.

Palavras-chave: Interdisciplinaridade; Paisagem agrícola; Conservação

\begin{abstract}
The interdisciplinary theme in Brazil is recent, still under construction and requires a continuous process of intellectual maturation. The purpose of this study is to reflect on the model of environmental conservation in agricultural landscapes starting from a model of interdisciplinary research content, considering it as essential to understanding the future of this line of research in agricultural landscapes. The study brings some considerations of critical position in the epistemological sense of the word for understanding the object society / nature or environment / society for conservation of biodiversity. This study, based on interdisciplinary process, sheds some light on the dialogue of knowledge building on the theoretical foundations of disciplinary knowledge production. That is, it is beyond merely disciplinary approaches and it articulated a cooperative dialogue between the social and natural sciences. Finally, it launches some challenges to what we call cultural interdisciplinary alliance and suggests that there is an interconnection of knowledge, practice and extension activities for environmental conservation in the basin of Corumbataí.
\end{abstract}

Keywords: Interdiciplinarity; Agricultural landscape; Conservation 


\subsection{Introdução}

Este estudo faz parte do projeto Temático Biota/FAPESP "Mudanças Sócioambientais no Estado de São e Perspectiva para Conservação" e foi desenvolvido junto ao Programa de Pós-Graduação em Ecologia Aplicada (ESALQ/CENA/USP), que tem como proposta a pesquisa, extensão e o ensino científico na área interdisciplinar de ecologia. Neste estudo, a interdisciplinaridade surgiu como aporte científico necessário para a pesquisa de caráter socioambiental na paisagem agrícola da Bacia do Corumbataí, onde, por meio de princípios da construção do conhecimento sobre a relação ambiente e sociedade, ou sociedade e natureza, perseguiu seus objetivos.

Nos capítulos anteriores observamos que nos últimos 30 anos a Bacia do Corumbataí passou do sistema agrário familiar arcaico ao vazio demográfico, da produção de commodities ao reconhecimento científico da necessidade de conservação dos recursos hídricos. Os resultados apresentados apontam que há na Bacia do Corumbataí uma forte evolução da pesquisa de caráter ecológico e conservacionista e, que nos frágeis espaços rurais da APA Corumbataí seus habitantes apresentam características sociais, econômicas e ecológicas que se relacionam e influenciam nos processos de conservação da natureza. Portanto, ao identificar por meio deste estudo de caso a incorporação das dimensões humanas e os desafios desta relação na conservação ambiental, este estudo assumiu o modelo técnico-científico interdisciplinar como uma tendência dos estudos de pesquisas conservacionistas em paisagens agrícolas. Assim, o presente estudo aliou as ciências da natureza com as ciências da sociedade, sugerindo que seja este um dos objetivos que a pesquisa interdisciplinar de caráter conservacionista em paisagens agrícolas tenda a exigir.

Após apresentados, discutidos e analisados os aspectos e os entendimentos a respeito do meio ambiente agrário, agricultura familiar, conservação e recursos hídricos em uma Bacia hidrográfica, buscamos entendimentos sobre a questão da interdisciplinaridade. Para nos orientar a respeito da interdisciplinaridade alguns questionamentos são feitos: Os problemas ambientais em paisagens agrícolas podem ser investigados mediante pesquisas interdisciplinares? O fato de reunir pesquisadores de diferentes áreas do conhecimento faz um projeto ser interdisciplinar? O processo interdisciplinar é um método de trabalho? Para irmos um pouco mais a fundo nestes questionamentos, vamos recorrer, entre outros, às colaborações de Almeida et al. (2004), Fazenda (2008), Garay e Becker (2006), Japiassu (2006), Leff (2001, 2002), Moran (2011), Pombo (2008) e Raynault e Zanoni (2011), e dessa forma propor 
que a conservação em paisagens agrícolas necessita da articulação, colaboração e da interação de diferentes áreas do conhecimento.

$\mathrm{Na}$ tentativa de responder às questões colocadas anteriormente e longe de esgotar essa discussão, recorremos tão somente aos exemplos obtidos neste estudo e na experiência empírica constatada durante sua execução, mesmo porque, a temática interdisciplinar no Brasil é recente, ainda em construção e requer um contínuo processo de amadurecimento intelectual. O objetivo deste capítulo é discutir e apresentar o modelo de conservação em paisagens agrícolas partindo de uma proposta de caráter interdisciplinar. Inicialmente traz algumas considerações de posicionamento crítico no sentido epistemológico da palavra, posteriormente aborda os domínios das pesquisas, os campos de conhecimento e a prática interdisciplinar. Desta forma, propomos refletir sobre o modelo de conservação ambiental em paisagens agrícolas partindo de um modelo de pesquisa de conteúdo interdisciplinar, considerando-o como essencial para compreender o futuro dessa linha da pesquisa e da própria Bacia do Corumbataí.

\subsection{Desenvolvimento}

\subsubsection{Situação da interdisciplinaridade}

Embora não tenhamos encontrado em nossa revisão uma definição clara, objetiva e comumente aceita sobre o que é interdisciplinaridade, percebemos que se trata de um conceito de utilização ampla e aplicado em muitos contextos. Para melhor compreendermos seu significado nos domínios da pesquisa científica de cunho interdisciplinar, recorremos a algumas definições que, de certa forma, são complementares, mas desafia a possibilidade de se estabelecer um conceito único.

A interdisciplinaridade pode ser entendida como uma anomalia do processo geral da pesquisa científica, e atualmente, na produção do conhecimento (LEIS, 2005). Para Raynaut e Zanoni (2011), as mudanças pelas quais a evolução do conhecimento científico varia de amplitude e de ritmo faz com que a interdisciplinaridade se caracterize por estar em permanente reconstrução. Por sua vez, sobre a experiência específica de um programa de pós-graduação em construção Almeida et al. (2004), colocam que a interdisciplinaridade é o princípio da exploração máxima das possibilidades de cada disciplina científica e da compreensão de seus limites, mas é antes de tudo, o princípio da diversidade e da criatividade. Na mesma linha, Fazenda (2008) diz ser a interdisciplinaridade uma nova atitude diante da questão do conhecimento, de abertura à compreensão de aspectos ocultos ao ato de aprender 
e, essa compreensão requer criatividade. Já a interdicisplinaridade proposta no saber ambiental (LEFF, 2001) tratou de associar os processos naturais e sociais, de visão holística e de forma integradora. Neste sentido, Kern et al. (2011), colocam que a interdisciplinaridade é a convergência de duas ou mais áreas do conhecimento, não pertencentes à mesma classe, que contribui para o avanço das fronteiras da ciências.

Pelo que foi colocado acima, falar sobre interdisciplinaridade é uma tarefa ingrata e ao mesmo tempo curiosa. Ainda que o termo possa ser considerado estável, ele por ser etéreo, vago, mutável de acordo com cada situação. Revisando, a coletânea 'Interdisciplinaridade em Ciência, Tecnologia \& Inovação’ (PHILIPPI Jr.; SILVA NETO, 2011), percebemos que são incontáveis e imensuráveis as definições, bem como, as bases epistemológicas que os vários autores se pautaram para definir ou se posicionarem sobre o termo. Pombo (2008), diz que a palavra tem sido usada, abusada e banalizada e, que de certa forma, entrou no vocabulário da investigação científica e dos novos modelos de comunicação entre pares. Coloca ainda que trata-se de um fenômeno da ciência contemporânea relativa às diversas experiências de reordenamentos disciplinares, e assinaladas como práticas de cruzamentos e práticas de importação, pautadas no reconhecimento da necessidade de transcender suas fronteiras. Nesse caso, Japiassu (2006, p.27), apresenta a interdisciplinaridade não apenas como uma categoria do conhecimento, mas de ação e, segundo o autor, precisa ser entendida e principalmente praticada.

De certo modo, notamos que a complexidade da pesquisa interdisciplinar impossibilita a existência de um único conceito que a defina, ou mesmo que haja um conceito unificado. No entanto, essa linha de pesquisa traz importantes colaborações no sentido de construir um conjunto de princípios filosóficos sobre a interdisciplinaridade, mas está longe de ser uma doutrina.

Várias distinções podem ser feitas quando se fala de interdisciplinaridade, assim, apontamos o que nos parece ser à colaboração deste trabalho, o qual foi concebido desde o início como interdisciplinar. Podemos dizer que o caminho percorrido desde o início neste estudo sobre sociedade e natureza foi inspirado na trajetória de Thomaz S. Khum (1962, 1978), que, ao transitar entre as ciências sociais, humanas e naturais , viveu a experiência da interdisciplinaridade de modo intenso, aproximando as ciências das humanidades. E ainda, na afirmação de Santos (2006, p. 33), quando diz, que, "na medida do possível, no estudo da sociedade todos os princípios epistemológicos e metodológicos que tratam da natureza, foi durante muito temo marginal, mas hoje é perseguido". Nesse caso, o estudo constitui-se, portanto, conforme preconiza Santos (2006), em reivindicar uma propositura epistemológica e 
metodológica própria, com base na especificidade do ser humano e sua relação com a natureza. Isso reforça a ideia que a interdisciplinaridade vem se revelando sistematicamente como campo de articulação de conhecimentos, tanto individuais, como é o caso deste estudo, como coletivos, entre programas e projetos de pesquisa.

As contribuições neste estudo, onde os temas principais foram a conservação ambiental e a agricultura familiar, suas variações estão centradas nas disciplinas ecologia/biologia e sociologia/história/antropologia. Assim, ao tentar entender as relações da sociedade na conservação da Bacia hidrográfica a partir da proposta interdisciplinar, obtevese pela compatibilidade do método proposto os resultados da pesquisa interdisciplinar, o qual dificilmente seria alcançado por conta de uma única disciplina. Para Rayanaut (2004), essa compatibilidade e variação metodológica podem e devem ser entendidas como processo interdisciplinar, que é sempre um processo firmado no diálogo entre disciplinas, firmemente estabelecido na sua identidade teórica e metodológica, mas também conscientes de seus limites e do caráter parcial do recorte da realidade sobre a qual operam. Foram, portanto, as variações disciplinares que ajudaram a entender melhor o objeto de estudo proposto e apresentado anteriormente, tendo, como pano de fundo, a base e a luz do método interdisciplinar que, por sua vez, permitiu as diversas construções apresentadas. De tal modo, a interdisciplinaridade como método precisa ser entendida no seu conceito teórico, mas como sugere Japiassu (2006) e Pombo (2008), também precisa ser praticada na forma que todo conhecimento teórico exige seu complemento prático. Por fim, podemos dizer com segurança, que a interdisciplinaridade é uma revolução cultural em andamento ou a própria evolução do pensamento científico, e se aplica bem à situação que experimentamos aqui.

\subsubsection{Situação da ciência: diferentes áreas do conhecimento e o projeto interdisciplinar}

Para melhor compreendermos os domínios da pesquisa de cunho interdisciplinar, vamos adotar uma postura em face da natureza complexa dos problemas com os quais temos nos deparado. A ilustração abaixo (Figura 1) representa uma aliança, chamada aqui de “aliança cultural interdisciplinar", entendendo que a cultura é o que representa e alia a capacidade de troca entre os saberes locais, científicos e também entre as disciplinas para que de fato ocorra a interdisciplinaridade. 


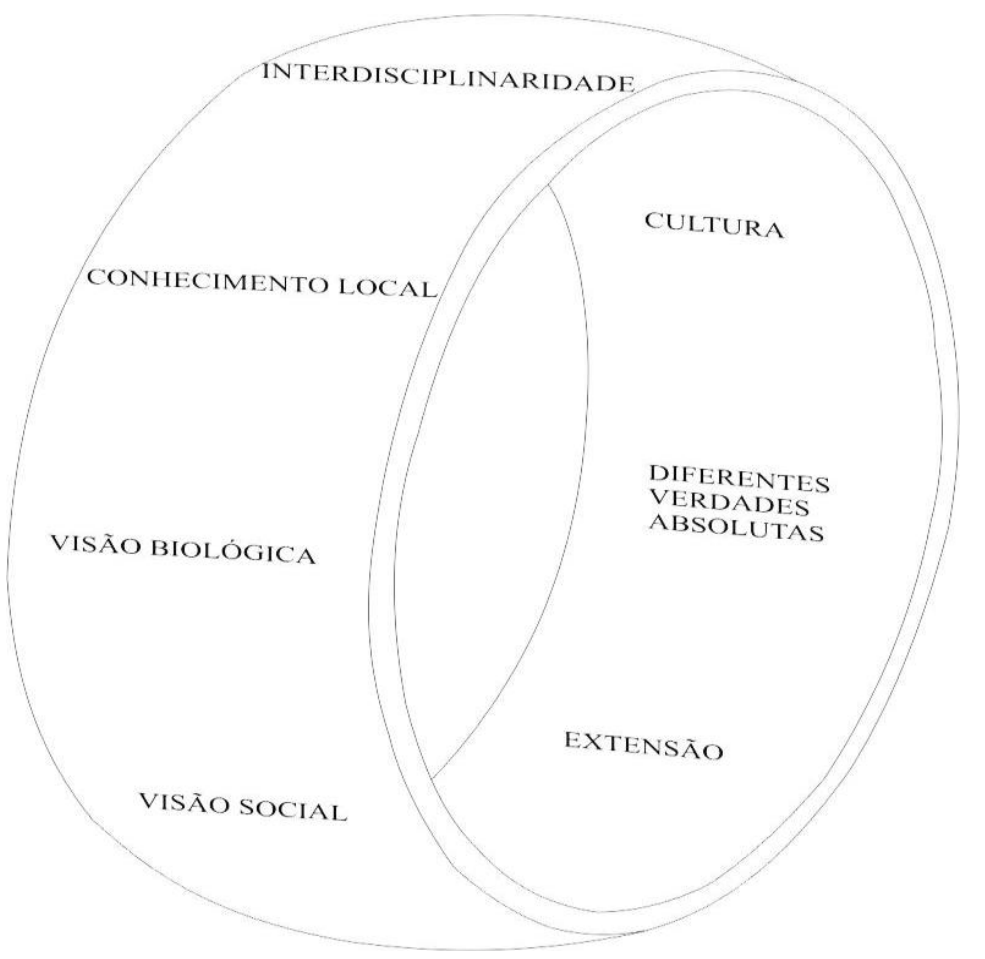

Figura 1 - Aliança Cultural Interdisciplinar

Muitas vezes os pesquisadores que trabalham com determinados temas híbridos como, por exemplo, biotecnologia, educação ambiental, nanotecnologia, ecologia histórica, etnoecologia, sociobiologia, ecologia evolutiva humana, engenharias de materiais, modelagem ambiental e sensoriamento remoto, áreas já consolidadas no mundo inteiro, dependem da articulação dos conhecimentos científicos de outras áreas, mas todos possuem uma base sólida da disciplina de onde veio.

Neste estudo, para o entendimento do objeto sociedade/natureza ou ambiente/sociedade com vista à conservação da biodiversidade, foram necessárias algumas junções do que preconizam os ecólogos da conservação e os cientistas sociais, no que se referem aos seus objetos, seus métodos, seus paradigmas, tendências e interfaces com a conservação de recursos comuns. Drew e Henne (2006) colocam que ao aproximar estes dois campos, com suas perspectivas holísticas sobre os valores e a força do conhecimento local, é possível obter resultados que auxiliem os projetos de conservação, obtendo inclusive, uma distribuição de benefícios mútuos e mais equitativos.

Para Moran (2011), o pesquisador disciplinar em ciências sociais tem uma curva de aprendizagem considerável antes de poder realizar contribuições importantes para o entendimento do problema ambiental e, o mesmo ocorre com os cientistas naturais antes de 
serem capazes de trabalhar sem percalços com os cientistas sociais e as dimensões humanas. Segundo Seixas (2005), para o entendimento e alinhamento destas questões sugere a pesquisa participativa, pois esta mobiliza diversas abordagens e técnicas que podem ser utilizadas, por exemplo, na gestão de recursos naturais. Já Berkes (2005), traz que os sistemas de recursos naturais e sistemas sociais interagem sob diferentes regimes de apropriação, mas que não existem soluções simples para os problemas relacionados à apropriação dos recursos. Portanto, no desafio de estudos de interações homem-ambiente referentes aos problemas ambientais contemporâneos, tanto a ciências sociais quanto as naturais tem sua cota de contribuição neste processo, oferecendo recursos narrativos para o campo interdisciplinar. Segundo Drew e Henne (2006), ainda é recente e pequeno o corpo de literatura que apresenta estudos de caso onde as ciências sociais e naturais têm trabalhado juntas e experimentado cada uma o seu conhecimento básico para produzir um sucesso sintético e renovador com projetos de base interdisciplinar. No Brasil um bom exemplo de sucesso é o Projeto TAMAR, que aliou a conservação de tartarugas e o envolvimento dos pescadores caiçaras por meio do entendimento das relações entre sociedade e natureza e, percebeu-se que conservação da espécie interessava também as pessoas envolvidas.

Entendendo a interdisciplinaridade como articulação das ciências, algumas considerações devem ser feitas, a primeira delas é que a formação disciplinar é absolutamente indispensável, não sendo possível fazer a interdisciplinaridade sem a alta competência disciplinar. Isso significa dizer que não existem possibilidades de obter bons resultado com base na interdisciplinaridade sem que se tenha um pouco de domínio efetivo dos campos disciplinares no qual se opera (POMBO, 2008). Portanto, podemos perguntar: O que o pesquisador interdisciplinar difere do disciplinar? Qual é a identidade dos projetos interdisciplinares? Como tais questões são contempladas na pesquisa interdisciplinares?

As respostas para estes questionamentos, a nosso ver, é que na "moda" da interdisciplinaridade o modelo de aliança proposto é capaz de revelar que homem, natureza, ecologia, ambiente e planeta podem ser entendidos como ponto de partida e ao mesmo tempo ponto de chegada. Como dito anteriormente, a interdisciplinaridade está intimamente relacionada com a cultura, porque todas as escolas disciplinares de pensamento no mundo estão a serviço da ciência e da construção do conhecimento. Portanto, é necessário partir da disciplinaridade para chegar à interdisciplinaridade. Embora não queiramos minimizar a eminente discussão, sugerimos que os problemas ambientais em paisagens agrícolas sejam conduzidos por pesquisas com objetivos comuns, onde o pesquisador tenha identidade 
cultural, filosófica e pratique a interdisciplinaridade gerando amplos benefícios, a partir de resultados coletivos da pesquisa interdisciplinar.

\subsubsection{Situação do conhecimento: problemas ambientais em paisagens agrícolas mediante pesquisas interdisciplinares}

Nas últimas décadas, vários campos do conhecimento vêm atuando com a temática interdisciplinar: a história, agricultura, medicina, ecologia e ciências sociais podem ser citadas como exemplos. Dadas às necessidades e complexidades na produção do conhecimento, gradualmente, a interdisciplinaridade tem se tornado uma força motriz em grandes centros de pesquisa no país, principalmente em centros públicos que tratam de questões relevantes de grandes áreas, como por exemplo, a conservação da biodiversidade. Segundo Leff (2001), vários programas de formação ambiental, surgidos nos anos 80 sob a temática do meio ambiente, adotaram a interdisciplinaridade como propósito explicito, contribuindo com avanços teóricos e epistemológicos no terreno da pesquisa.

No Brasil, a pesquisa acadêmica de caráter interdisciplinar é recente, tendo a Comissão Multidisciplinar, criada pela Coordenação de Aperfeiçoamento de Pessoal de Nível Superior - CAPES, em 1999, e a Associação Nacional de Pesquisa e Pós-Graduação em Ambiente e Sociedade -ANPPAS em 2001 (ALMEIDA et al., 2004). Atualmente, a CAPES dedica uma área especifica para programas de pós-graduação de caráter interdisciplinar no processo de desenvolvimento da ciência e da tecnologia no país. Segundo Raynaut e Zanoni (2011), o país está desempenhando um papel pioneiro no esforço de renovação de produção e transmissão de saberes, principalmente através de colaborações inéditas entre pesquisadores de diferentes disciplinas. Na CAPES, foi a partir de 2000, que as áreas interdisciplinares passaram a ter os primeiros programas, e hoje é a maior área de programas de pós-graduação brasileira, seguido pela área das ciências agrárias. Isto significa que no Brasil, os programas de pós-graduação estão formando gradualmente pesquisadores e profissionais com o perfil interdisciplinar (PHILLIPPI Jr; SILVA NETO, 2011).

No Programa de Pós-Graduação em Ecologia Aplicada - PPGI-EA (ESALQ/CENA/USP), entre 2008 e 2012, um grupo de pesquisadores, de diferentes formações, reuniram-se em torno do projeto de pesquisa "Mudanças sócio-ambientais no estado de são Paulo e perspectiva para conservação" (Biota/Fapesp). Cabe ressaltar que a ideia do projeto temático foi concebida anos antes, como necessidade de maior entendimento da situação ambiental na paisagem agrícola com vistas à conservação (DOTTA; VERDADE, 
2007, 2009, 2011; GHELER-COSTA et al., 2012). No projeto supracitado a principal inovação no campo ambiental era propor um diálogo entre pesquisadores de diferentes áreas e apresentar uma perspectiva histórica na abordagem ambiental, além de assumir o caráter socioambiental integrado por diferentes abordagens (ALMEIDA Jr et al., 2011). O projeto envolveu diversos aspectos correlacionados, entre eles, o ecológico, o sociológico, o artístico, o antropológico, o histórico, o midiático e o biológico, destacando-se como um projeto que envolveu diferentes modalidades de pesquisa e pesquisadores. A seu modo, uma proposta com essa magnitude consistia naturalmente como um conjunto de estudos de caráter interdisciplinar, que em torno de uma estrutura comum abordava entre outros, a problemática ambiental, social, política e entendimentos para conservação numa região geográfica comum a todos, a Bacia Hidrográfica do Rio Corumbataí, no estado de São Paulo.

A equipe original do projeto era constituída de especialistas em Agronomia, Ecologia, Geografia, Antropologia, Sensoriamento Remoto, Sociologia e Mídia, todos parte do corpo docente ou de pesquisa do PPGI-EA, além dos pós-graduando. Segundo Almeida Jr et al. (2011) as diferenças, as lacunas e as distâncias foram fatores determinantes para instituir um processo de diálogo visando uma maior integração e coerência entre as atividades de pesquisas desenvolvidas. Durante a construção do projeto, mesmo que extrapolando os campos disciplinares, tinha-se a clareza da individualização dos métodos empregados em cada área do conhecimento, bem como, referentes às suas metodologias qualitativas ou quantitativas (Almeida Jr et al. 2011).

No entanto, especificamente na linha temática ambiente e sociedade, pouco se evoluiu para efetiva co-participação em torno de objetivos comuns, mesmo onde as propostas de pesquisas se aproximavam em termos de objeto, elas se distanciavam em termos de sujeito. Isto ocorreu provavelmente pelas divergências entre os objetivos das pesquisas relacionadas a cada área de conhecimento. Valho-me aqui, de uma colocação feita por Almeida et al., (2004), com a qual concordo por se aproximar do vivenciado durante a realização deste estudo: "os pesquisadores sentem dificuldades em integrar-se em um projeto dessa natureza, ora por não terem ainda os objetivos científicos bem definidos, ora por recusarem-se a flexibilizar suas certezas e garantias de estabilidades construídas em seu subcampo de pesquisa ou de conhecimento específico". Outra análise que se acrescenta a esta última é referente ao distanciamento entre os alunos pesquisadores de pós-graduação da linha temática ambiente e sociedade, que não participaram de forma efetiva e participativa durante a execução do projeto temático. 
Entre os estudos realizados na linha temática ambiente/sociedade/ruralidade na Bacia do Corumbataí estão os trabalhos acadêmicos de Sakaguti Jr. (2010), que investigou os significados das paisagens pela lente das representações simbólicas e representações sociais, refletiu sobre a complexidade nos processos de transformações do espaço rural e apontou como principais problemas ambientais a escassez de água, erosão, queimadas e danos provocados por javalis; Fraccaro (2011) identificou categorias e padrões da percepção ambiental da população rural pelo referencial teórico da ecologia humana, propondo que, a forma com que o produtor rural percebe o ambiente é construída por questões econômicas e históricas, propondo que as políticas públicas ambientais só serão eficientes quando as questões humanas e sociais forem vistas como partes integrantes dos problemas ambientais; Silva (2011), avaliando a integração dos saberes da população rural em relação aos recursos naturais, conclui que a gestão ambiental local não é considerada pela gestão ambiental pública, e o estudo de Oliveira (2012), que através da observação participante e interpretações de Nobert Elias, conceito de habitus de Bourdie, e na teoria das sociedades de risco de Ulrich Beck, constatou que no discurso dos membros do conselho gestor da APA Corumbataí existe uma grande preocupação com a preservação dos recursos naturais, e que a agricultura familiar tem o perfil mais adequado para o desenvolvimento rural na APA.

É necessário antes de qualquer discussão, reconhecer que estudos individuais realizados dentro da proposta do projeto temático realizado na Bacia do Corumbataí, com a temática sociedade/natureza/gestão/ruralidades, são interdisciplinares e complementares ao presente estudo. No sentido construtivo, nota-se que, individualmente, os estudos abordam questões similares, cada um na sua ótica, com sua base teórica e metodológica e todos com olhar comum para a Bacia e seus problemas sócio-ambientais. Nota-se ainda que, individualmente, os estudos se aproximam nas suas conclusões e, quando analisados coletivamente, apontam para necessidade da inserção da população rural na conservação ambiental. Portanto, como no presente estudo, sugerem que é na participação da comunidade rural que está a melhor perspectiva para a conservação da paisagem agrícola. No entanto, os estudos conduzidos junto ao projeto temático, na linha temática ambiente e sociedade, cada um com sua metodologia, produziram conhecimentos interdisciplinares em relação à área de estudo, mas houve pouca comunicação, bem como pouca interação entre os pesquisadores e participantes do projeto. Fica claro que os projetos interdisciplinares, como uma necessidade da ciência moderna, devem avançar em certas áreas do conhecimento, sendo necessário que várias especialidades caminhem juntas, pois sozinhas dificilmente chegarão a algum lugar. 
De certa forma, o que foi exposto de modo algum compromete a proposta do projeto temático original, muito menos dos estudos individuais, ao contrário, mostra que é possível que a articulação disciplinar, posta sobre uma proposta interdisciplinar, gere conhecimentos e proposituras sobre a conservação ambiental em paisagens agrícolas. Entretanto, a atuação interdisciplinar permite, possibilita e muitas vezes pede a revisão de valores morais e éticos, inovando na formação humanista dos pesquisadores. Da mesma forma, é necessário interromper a consciência individual para que haja cooperação e construção coletiva nas áreas do conhecimento (POMBO, 2008).

\subsubsection{Situação de hoje: o processo interdisciplinar é um método de trabalho}

Muitas vezes o entendimento da construção interdisciplinar passa pela ideia de um estudo que agrega diferentes áreas do conhecimento, em torno de um ou mais temas, mas que cada área de conhecimento preserva e utiliza a sua metodologia e sua independência. Há que se chamar atenção desde já que, atuar na área interdisciplinar não é tarefa fácil, porque saímos de uma região de conforto disciplinar onde se tem maior domínio para adentrar em um campo muitas vezes desconhecido do seu rigor epistemológico.

A interdisciplinaridade como método, sugere que é preciso entender como as disciplinas podem se relacionar, para que juntas permitam o estabelecimento de diálogos com as variações inicialmente disciplinares. Segundo Pombo (2006) não há necessidade explícita da presença de muitas disciplinas para atuação interdisciplinar, pelo contrário, muitas vezes isso é contra producente. De acordo com Moran (2011), o caráter interdisciplinar da pesquisa pode ajudar a entender os fatores das perdas da biodiversidade em paisagens agrícolas, e este se encontra no campo da ciência da sustentabilidade, ou pesquisa das dimensões humanas das mudanças globais. Foram, portanto, as variações das disciplinas centradas na ecologia e sociologia que nos permitiram entender e estudar o fenômeno da conservação ambiental a partir da compreensão da agricultura familiar.

O presente estudo com base no processo interdisciplinar ressaltou o diálogo de saberes proposto por Leff (2002), e buscou nos fundamentos teóricos da produção de conhecimento disciplinar supostas relações com a conservação ambiental por meio de metodologias alternativas, ou seja, foi além dos enfoques unicamente disciplinares, e articulou um diálogo cooperativo entre as ciências sociais e naturais. Esse diálogo permitiu observar que as práticas sociais nas dinâmicas ambientais são fundamentalmente possíveis a partir de um método interdisciplinar. De certa forma, alguns cuidados relacionados aos métodos interdisciplinares 
devem estar sempre claros e evidentes: questionamento das bases ou aspectos teóricos e conceituais que determinarão a problemática a ser investigada; a identificação do problema; das hipóteses e resultados esperados.

Especificamente para este estudo sabíamos que os métodos da sociologia e da ecologia são completamente diferentes, sendo o primeiro descrito como indutivo, pautado na observação e análise qualitativa; e o segundo mais dedutivo e quantitativo. Todavia, foi neste sentido que o diálogo científico abordado neste estudo foi construído metodologicamente como interdisciplinar, analisando os aspectos e os entendimentos das pesquisas tidas como disciplinares na Bacia do Corumbataí. Por sua vez, este estudo envolveu o meio agrário, agricultura familiar, conservação ambiental e social e os recursos hídricos na mesma Bacia hidrográfica, e propõe que na pesquisa interdisciplinar, a conservação não é somente ecológica, e sim, composta por várias disciplinas. Portanto, a interdisciplinaridade na forma que foi abordada neste estudo pode ser tratada como um método de convergência científica que deve ser transmitido dentro da própria ciência.

\subsection{Considerações Finais}

Hoje sabemos que o processo interdisciplinar é um método de trabalho de convergência e transferência de conceitos, técnicas, práticas e requer visão holística principalmente no seu sentido cultural. Alguns desafios são lançados aqui para o que chamamos de aliança cultural interdisciplinar, sugerindo que haja uma interligação de conhecimentos e de saberes para conservação ambiental na Bacia do Corumbataí. Portanto, como perspectiva interdisciplinar para conservação de paisagens agrícolas sugere-se:

- Ampliar as bases conceituais através do conhecimento gerado em outras universidades, outros institutos e outros programas de pós-graduação por meio de uma rede de cooperação regional;

- Consolidar e compartilhar bases de dados com linguagem acessível e de livre acesso para população em geral, inclusive o setor empresarial;

- Interagir de forma a compartilhar as relações de objetos de pesquisas distintos de diferentes áreas do conhecimento;

- Contribuir com os processos de discussão de projetos interdisciplinares, um consenso científico na busca de respostas para objetivos comuns;

- Instrumentalizar os projetos comuns com leituras da mesma natureza e organização de grupos de pesquisas; 
- Participar e promover eventos científicos de caráter interdisciplinar, uma vez que os problemas da pesquisa interdisciplinar requerem (enfrentamentos teóricos e metodológicos construtivos).

Por fim, a conservação na paisagem agrícola e a gestão dos recursos hídricos necessitam do entendimento de como a sociedade participará das propostas de gestão e nas tomadas de decisão. O problema pode ser de governança, ou seja, o estado é ausente e não oferece um serviço eficiente e de extensão rural. Da mesma forma, Japiassu (2006, p.27), coloca que a interdisciplinaridade é uma categoria de ação e precisa ser praticada no sentido da extensão da pesquisa científica.

\section{Referências}

ALMEIDA Jr, A.R.; MOLINA, S.M.G.; MARTINANI, L.A.; BALLESTER, M.V. R.; GARAVELLO, M.E.P.E.; VERDADE, L.M.; VICTORIA. R.L. Interação interdisciplinar: a experiência da Pós-Graduação em Ecologia Aplicada da USP. In: PHILIPPI JR., A.; SILVA NETO, A.J. Interdisciplinaridade em Ciência e Tecnologia. Barueri: Manole, 2011. p. 298324.

ALMEIDA, J.; GERHARDT, T.E.; MIGUEL, L.A.; NETTO, C.G.A.M.; VERDUM, R.; BECK, F.L.; ZANONI, M. Pesquisa interdisciplinar na pós-graduação: (des)caminhos de uma experiência em andamento. Revista Brasileira de Pós-Graduação, São Paulo, v.1, n.2, p. 116-140, 2004.

BERKES, F. Sistemas sociais, sistemas ecológicos e direitos de apropriação de recursos naturais. In: VIEIRA, P.F.; BERKES, F.; SEIXAS, C.S. Gestão integrada e participativa de recursos naturais: conceitos, métodos e experiências. Florianópolis: Secco/APED, 2005. p.47-72.

DREW, J.A.; HENNE, A.P. Conservation biology and traditional ecological knowledge: Integrating academic disciplines for better conservation practice. Ecology and Society, Nova Scotia, v.1, n. 2, p. 34, 2006.

DOTTA, G. ;VERDADE, L.M. Trophic categories in a mammal assemblage: diversity in an agricultural landscape. Biota Neotropica, São Paulo, v.7, n. 2, p. 287-292, 2007.

DOTTA, G .; V ERDADE, L.M. Felids in an agricultural landscape in São Paulo Brazil. Cat News, London, v. 51, p24-27, 2009.

DOTTA, G.; VERDADE, L.M. Medium to large-sized mammals in agricultural landscapes of South-eastern Brazil. Mammalia, Paris, v. 75, p. 345-352, 2011.

FAZENDA, I.C.A. (Org.). O que é Interdisciplinaridade? São Paulo: Cortez, 2008. 199p. 
FRACCARO, L.C.Z. Percepção ambiental e uso de recursos naturais: a população rural de Ipeúna , SP. 2011. 125p. Dissertação (Mestrado em Ecologia Aplicada) - Escola Superior de Agricultura Luiz de Queiroz, Universidade de São Paulo, 2011.

GARAY, I.G.; BECKER, B.K. As Dimensões Humanas da Biodiversidade. O desafio das novas relações sociedade-natureza no século XXI. Petrópolis: Vozes, 2006. 483p.

JAPIASSU, H. O sonho transdisciplinar e as razoes da filosofia. Rio de Janeiro: IMAGO, 2006. 237p.

KUHN, T. A teoria das revoluções científicas. Chicago: University of Chicago Press, 1970. $262 p$.

LEFF, E. Epistemologia ambiental. 3. ed. São Paulo: Cortez, 2002. 240p.

LEFF, E. Saber Ambiental: sustentabilidade, racionalidade, complexidade, poder. Petrópolis: Vozes, 2001. 494p.

LEIS, H.R. Sobre o conceito de interdisciplinaridade. Cadernos de Pesquisa

Interdisciplinar em Ciências Humanas, Florianópolis, n. 73, ago. 2005. Disponível em: <http://www.cfh.ufsc.br/ dich/TextoCaderno73.pdf $>$. Acesso em: 26 nov.2012.

MORAN, F.E. Meio Ambiente e Ciências Sociais: interações homem-ambiente e sustentabilidade. São Paulo: Senac, 2011. p. 307.

MORAN, E. F., OSTROM, E. Seeing the Forest and the Trees: Human Environment Interactions in Forest Ecosystems. MIT Press: Cambridge, MA, 2005.

OLIVEIRA, K.A. Estudo da percepção ambiental em torno das entidades gestoras e dos sujeitos envolvidos com políticas e programas de interesse público para o desenvolvimento rural sustentável da bacia do rio Corumbataí com políticas e programas de interesse público para o desenvolvimento rural sustentável da Bacia do Rio Corumbataí. 2012. 99p. Dissertação (Mestrado em Ecologia Aplicada) - Escola Superior de Agricultura “Luiz de Queiroz”, Universidade de São Paulo, Piracicaba, 2012.

PHILIPPI JR., A.; SILVA NETO, A.J. Interdisciplinaridade em Ciência e Tecnologia. Barueri: Manole, 2011. 998p.

POMBO, O. Práticas Interdisciplinares. Sociologias, Porto Alegre, v. 8, n. 15, p. 208-249, jan/jun 2006.

POMBO, O. Epistemologia da interdisciplinaridade. Revista do Centro de Educação e Letras da UNIOESTE, Foz do Iguaçú, v. 10, n. 1, p. 9-40, 2008.

RAYNAULT, C.; ZANONI, M. Reflexões sobre princípios de uma prática interdisciplinar na pesquisa e no ensino superior. In: PHILIPPI JR., A.; SILVA NETO, A.J.

Interdisciplinaridade em Ciência e Tecnologia. Barueri: Manole, 2011. p. 143- 208.

RAYNAUT, C. Meio ambiente e desenvolvimento: construindo um novo campo do saber a partir da perspectiva interdisiciplinar. In: LIMA, M.V.; MENDONÇA, F. (Org.). 
Desenvolvimento e Meio Ambiente - interdisicplinaridade, meio ambiente e desenvolvimento: desafios e avanços do ensino e da pesquisa. Curitiba: editora UFPR, 2004. 192p.

SAKAGUTI,JR, M.M. Significados das paisagens da microbacia do Ribeirão dos Sinos, Ipeúna, SP. 2010. 201p. Dissertação (Mestrado em Ecologia Aplicada) - Escola Superior de Agricultura “Luiz de Queiroz”, Universidade de São Paulo, Piracicaba, 2010.

SANTOS, B.S. Um discurso sobre as ciências. São Paulo: Cortez, 2006. 92p.

SEIXAS, C.S. Abordagens e técnicas de pesquisa participativa em gestão de recursos naturais. In: VIEIRA, P.F.; BERKES, F.; SEIXAS, C.S. (Org.). Gestão Integrada e Participativa de Recursos Naturais. Florianópolis: APED Editora, 2005. p. 73-105.

SILVA, M.P. Integração de saberes na gestão dos recursos naturais : caso do município de Ipeúna, SP. 2011. 195p. Dissertação (Mestrado em Ecologia Aplicada) - Escola Superior de Agricultura "Luiz de Queiroz", Universidade de São Paulo, Piracicaba, 2010. 


\section{ANEXOS}


ANEXO A - Sistematização de produção científica realizada na bacia do Corumbataí (BDTD- Biblioteca Brasileira de teses e dissertações; BUSP - Biblioteca Digital da Universidade de São Paulo; BUNESP - Biblioteca digital da Universidade Estadual Paulista; BUNICAMP - Biblioteca da

Universidade de Campinas; BUFSCar - Biblioteca digital da Universidade Federal de São Carlos; BEMBRAPA - Biblioteca digital da Empresa Brasileira de Pesquisa Agropecuária; Banco de dados de periódicos da Coordenação de Aperfeiçoamento de Pessoal de Nível Superior; Banco de dados Web of Science; Banco de dados SCIELO, Banco de dados SCOPUS) (continua)

continua)

\begin{tabular}{|c|c|c|c|c|c|c|c|c|c|c|}
\hline Palavras-chave & BDTD & BUSP & BUNESP & BUNICAMP & BUFSCar & BEMBRAPA & Periódicos CAPES & Webof Science & SCIELO & SCOPUS \\
\hline Vegetação nativa & 4 & 5 & 1 & 1 & 0 & 3 & 13 & 3 & 6 & 5 \\
\hline Eucalipto & 2 & 3 & 0 & 0 & 0 & 1 & 6 & 0 & 1 & 1 \\
\hline Cana de açúcar & 8 & 16 & 3 & 1 & 0 & 7 & 15 & 2 & 1 & 2 \\
\hline Pastagem & 5 & 7 & 1 & 0 & 0 & 2 & 7 & 0 & 0 & 0 \\
\hline Agrotóxico & 2 & 1 & 0 & 0 & 0 & 0 & 12 & 2 & 1 & 2 \\
\hline Poluição & 6 & 16 & 7 & 2 & 0 & 2 & 32 & 5 & 1 & 6 \\
\hline Fragmentação & 9 & 10 & 2 & 1 & 0 & 3 & 16 & 2 & 2 & 3 \\
\hline Biodiversidade & 9 & 14 & 1 & 1 & 0 & 1 & 15 & 1 & 0 & 5 \\
\hline Água & 29 & 47 & 30 & 3 & 0 & 10 & 108 & 19 & 14 & 33 \\
\hline Solo & 25 & 41 & 27 & 2 & 2 & 21 & 63 & 10 & 10 & 13 \\
\hline $\begin{array}{l}\text { Meio ambiente } \\
\text { Educação }\end{array}$ & 18 & 25 & 22 & 5 & 0 & 5 & 71 & 11 & 2 & 15 \\
\hline $\begin{array}{l}\text { ambiental } \\
\text { Agricultura }\end{array}$ & 4 & 10 & 7 & 0 & 0 & 0 & 6 & 0 & 0 & 0 \\
\hline familiar & 1 & 0 & 0 & 0 & 0 & 0 & 1 & 0 & 0 & 0 \\
\hline Gestão ambiental & 4 & 10 & 9 & 0 & 0 & 0 & 21 & 2 & 0 & 3 \\
\hline Sociologia & 0 & 5 & 0 & 0 & 0 & 0 & 0 & 0 & 0 & 0 \\
\hline Antropologia & 0 & 0 & 0 & 0 & 0 & 0 & 0 & 0 & 0 & 0 \\
\hline Sustentabilidade & 3 & 8 & 2 & 0 & 0 & 2 & 8 & 1 & 1 & 1 \\
\hline Meio rural & 6 & 12 & 3 & 0 & 0 & 0 & 11 & 1 & 2 & 5 \\
\hline Ruralidades & 0 & 0 & 0 & 0 & 0 & 0 & 0 & 0 & 0 & 0 \\
\hline Sociologia rural & 0 & 2 & 0 & 0 & 2 & 0 & 0 & 0 & 0 & 0 \\
\hline Agricultura & 33 & 16 & 2 & 3 & 0 & 8 & 19 & 2 & 0 & 4 \\
\hline
\end{tabular}


ANEXO A - Sistematização de produção científica realizada na bacia do Corumbataí (BDTD- Biblioteca Brasileira de teses e dissertações; BUSP Biblioteca Digital da Universidade de São Paulo; BUNESP - Biblioteca digital da Universidade Estadual Paulista; BUNICAMP -

Biblioteca da Universidade de Campinas; BUFSCar - Biblioteca digital da Universidade Federal de São Carlos; BEMBRAPA -

Biblioteca digital da Empresa Brasileira de Pesquisa Agropecuária; Banco de dados de periódicos da Coordenação de Aperfeiçoamento de Pessoal de Nível Superior; Banco de dados Web of Science; Banco de dados SCIELO, Banco de dados SCOPUS) (continuação)

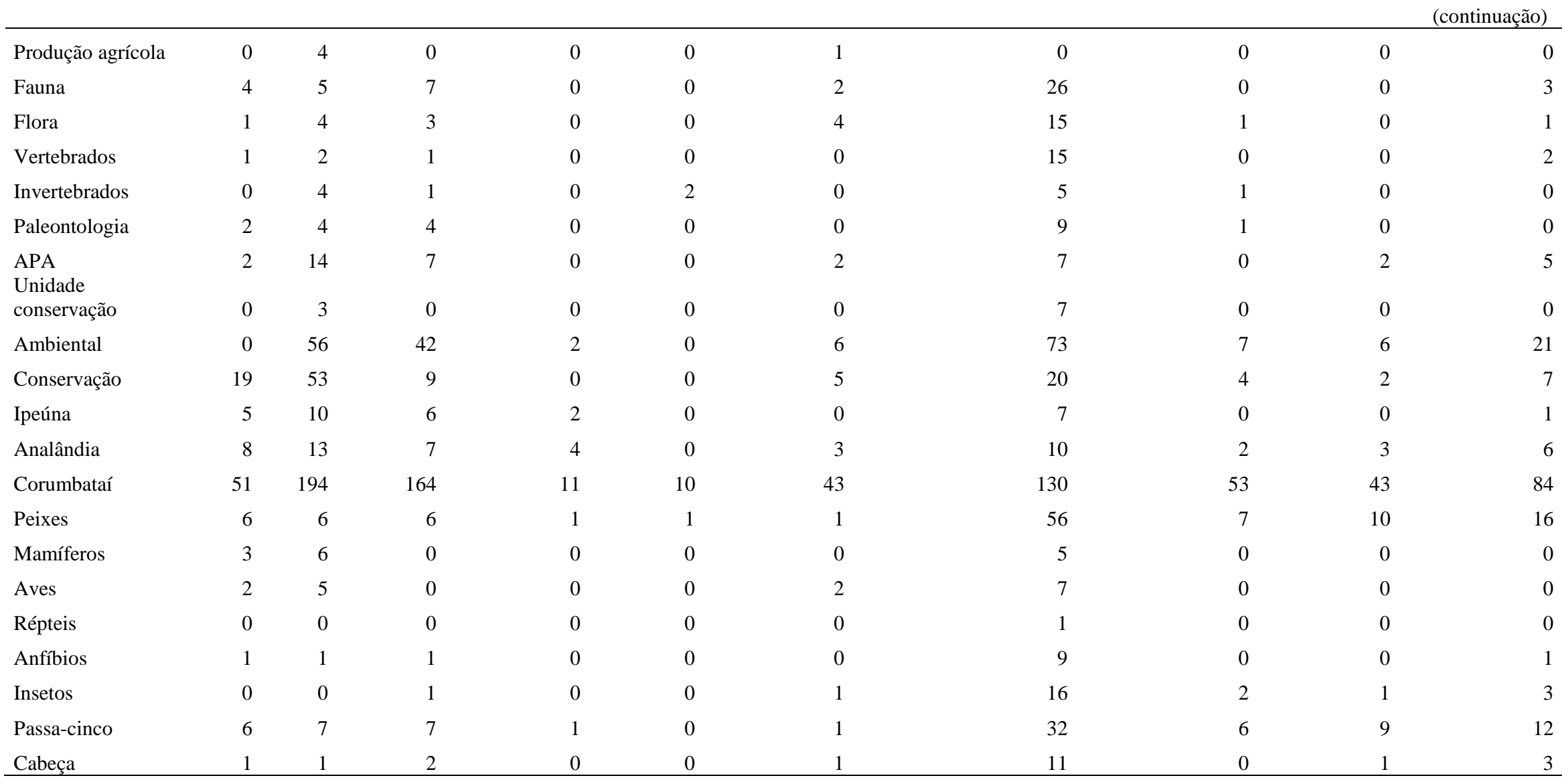


ANEXO B: Questionário proposto pelo autor (baseado no trabalho desenvolvido pelo INCRA/FAO (2010).

\section{$\underline{\text { Relações entre o meio rural e o meio ambiente perspectiva para a conservação }}$ da APA - Corumbataí -SP}

Data: / / Entrevista $\mathrm{n}^{\mathrm{o}}$ : Início: h__ m Término: $\mathrm{h} \_\mathrm{m}$

Coordenadas utm:

$\square$ Ipeúna $\square$ Corumbataí $\square$ Analândia Matriz:

Local: $\square$ faz. $\square$ sitio $\square$ chácara.: Tamanho: alq. ha

Nome:

Profissão/ocupação:

$\square$ Proprietário $\quad \square$ Arrendatário $\square$ Meeiro $\quad \square$ Empregado

1-Reside na propriedade: $\square \operatorname{sim} \square$ não $\square$ já morou? quanto tempo?

2- Casas de empregados: $\square$ sim quantas? 口não.

- Número de famílias na propriedade: quantas pessoas:

- Número de crianças na propriedade:

- Freqüentam escola: Onde?

3- Existem: Rios ; Córregos ;Nascentes ; Cachoeiras ; Lago

4- A água propriedade, de onde vem ? E como é utilizada?
$\square$ do córrego/rio
$\square$ nascente
$\square$ poço artesiano
$\square$ encanada
$\square$ outros
$\square$ consumo
口irrigação
$\square$ animais

5- Os locais com água, tem a mata ciliar $\square$ sim $\square$ não $\square$ em partes (+ ou -)

6- O senhor (a) sabe o que é APP? $\square \operatorname{sim} \square$ não

7- O Sr(a) sabe o que é Reserva legal e sua obrigatoriedade de averbação? O que pensa sobre? $\square$ sim $\square$ nãoR:

8- O senhor (a) ou alguém da família pesca? $\square$ sim $\square$ não onde? quais os peixes 
9- Nos últimos anos, houve alterações na qualidade da água do rio? E na quantidade de peixes?

$\square \operatorname{sim} \square$ não R:

10- Qual a sua escolaridade? Até que ano o senhor (a) estudou?
$\square \quad 1^{\circ}$.grau
$\square 2^{\circ}$.grau
$\square 3^{\circ}$.grau

11- Há quanto tempo a propriedade pertence à família? $\square-5 \quad \square 6 / 15 \quad \square 16 / 30 \square+30$ anos

12- Atualmente quais são os tipos de uso da terra na propriedade?

$\begin{array}{cccc}\text { alq/pasto } & \text { __alq/benfeitorias } & \text { _alq/floresta } & \text { _alq./cerrado } \\ \text { alq/cana } & \text { _alq/eucalipto } & \text { __alq/perenes } & \text { __alq/anuais }\end{array}$

13- As atividades desenvolvidas na propriedade representam quanto na renda da família?

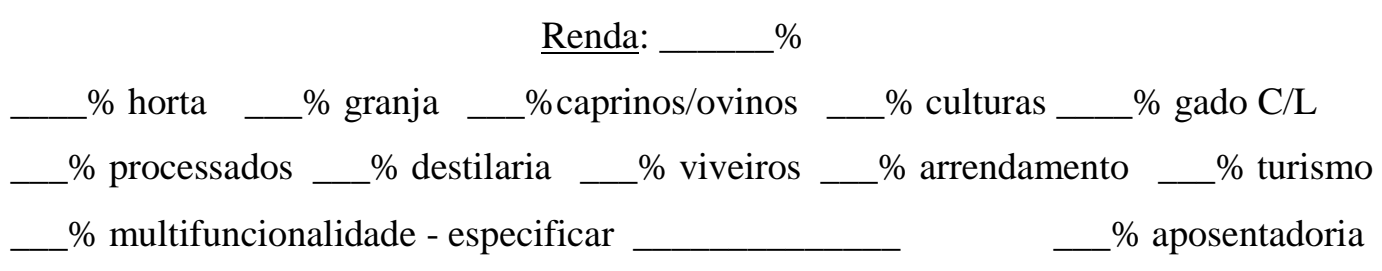

14- A renda somando todos os ingressos de todas as pessoas é :

$\square$ até $3 \square$ de 3 a $7 \square$ de 7 a $12 \quad \square$ mais de 12 salários mínimos

15- O que já foi produzido nessa terra?

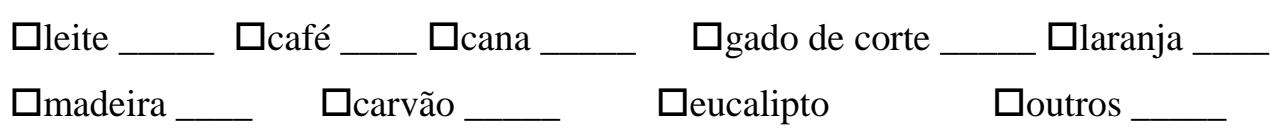

16 - Desde o tempo em que o senhor (a) mora aqui o que melhorou e piorou com as mudanças ocorridas nos usos da terra? Por quê? $\square$ social $\square$ ambiental $\square$ econômico

$\mathrm{R}:$

17- Qual o critério na escolha do produto a serem produzidos?

$\square$ facilidade de produção $\square$ gosto $\square$ costume/tradição $\square$ interesse comercial $\square$ condições ambientais

18- Quantas pessoas trabalham na propriedade atualmente?

___Registrados __ Temporários __Empreita __ Sociedade

19 - Insumos agrícolas na propriedade? 
$\square$ trator, $\square$ arado, $\square$ grade, $\square$ destilador, $\square$ usinagem, $\square$ leiteria, $\square$ outros.

20- Qual o destino da produção?

\section{$\square$ venda}

$\square$ in natura

$\square$ processado

$\square$ geléias,

compotas

$\square$ bebidas,

$\square$ pães

$\square$ embutidos,

$\square$ queijo.

\section{$\square$ consumo}

$\square$ in natura

$\square$ processado

$\square$ geléias, compotas

$\square$ bebidas, $\square$ pães

$\square$ embutidos

$\square$ queijo,

\section{$\square$ doação}

$\square$ famliar

$\square$ vizinho

$\square$ outros

Por que não vende?

$\square$ não compensa financeiramente

$\square$ não há comprador

$\square$ dificuldade em chegar até local de venda

A fonte de matéria-prima é produzido na propriedade $\%$ ou comprado $\%$

O quanto essas atividades incrementam na renda familiar? $\%$

\section{1- Quintais}

Área aproximada do quintal

Quem toma conta do quintal?

Quem resolve o que vai ser plantado e/ou criado?

Principais espécies vegetais- hortaliças ( ) ornamentais ( ) frutíferas ( ) medicinais

22 - Qual o local de aquisição dos alimentos?
$\square$ mercado
$\square$ feira
sítios vizinhos
hortas
ambulante

- Mantimentos

- Carne

- Legumes

- Frutas

- Hortaliças

- Embutidos

- Laticínios

- Pães e similares

23 - O senhor consome produtos semi-prontos? Quais? Com qual frequência?

$\square$ sim $\square$ não R:

24 - Qual é o gasto em média com alimentação por mês? R\$_ 
$\mathrm{R}:$

25- Acha que em sua casa se come bem? Por quê?

$\mathrm{R}:$

26 - Para o senhor (a) o que é uma boa alimentação?

$\mathrm{R}:$

27- A renda de sua família dá para comer como se gostaria?

$\mathrm{R}:$

28 - O que o senhor acha que não pode faltar em sua casa, para a alimentação?

$\mathrm{R}:$

29 - Você considera que sua alimentação melhorou ou piorou? Por quê?

$\mathrm{R}:$

30- Você já ouviu falar sobre os alimentos transgênicos?

$\mathrm{R}:$

31 - O senhor (a) já plantou ou plantaria cana ou outra cultura transgênica na sua propriedade?

$\mathrm{R}:$

32 - O Senhor (a) têm o conhecimento dos microcréditos? Já fez ou faz algum tipo de financiamento? $\square \operatorname{sim} \square$ não Por que? 
ANEXO C: Roteiro de entrevista proposto pelo autor.

\begin{tabular}{|c|c|c|}
\hline $\begin{array}{l}\text { Tópicos para } \\
\text { entrevista }\end{array}$ & Inundação & Instalações \\
\hline Local & Fogo & Equipamentos \\
\hline Área & Animais silvestres (conh.) & Próprios \\
\hline Propriedade & Seca (sazonalidade) & Coletivos \\
\hline Arrendamento & Inundação & Alugados \\
\hline Posse & Fogo & Credito (banco) \\
\hline Mão de obra & Animais silvestres (conh.) & Produtos \\
\hline Familiar & Rio & Sub-produtos \\
\hline Assalariada & Peixes & Processamento \\
\hline Produção Familar & História ecológica (uso) & Comercialização \\
\hline Patronal & Cultivo & Armazenagem \\
\hline Capitalista & No passado & Custos \\
\hline Impostos & Técnicas agrícolas & Autoconsumo \\
\hline Relevo & Insumos (vegetal/animal) & Aquisição \\
\hline Solo & Biológicos & Prioritários \\
\hline Disponibilidade de água & Químicos & Supérfluos \\
\hline Diversidade agrícola & Origem & Relação de trocas \\
\hline Entorno (vizinhança) & Próprio & Renda \\
\hline $\begin{array}{l}\text { Cobertura vegetal } \\
\text { natural (frag.) }\end{array}$ & Comprado & Produção e renda \\
\hline Legislação & Pastagem & Capitalizado \\
\hline APP & Rebanhos & Descapitalizado \\
\hline RL & Dejetos & Em Expansão \\
\hline PSA & Rotação Cultura & Em Transição \\
\hline Seca (sazonalidade) & Instalações & Em Declínio \\
\hline
\end{tabular}


ANEXO D: Tabela das variáveis sócio-ambientais (presença e ausência) da agricultura familiar na APA Corumbataí, elaborada pelo autor.

\begin{tabular}{|c|c|c|c|c|c|c|c|}
\hline Dados sobre Recursos Hídricos & Rio & Nascente & $\begin{array}{c}\text { Nasc. } \\
\text { Interm. }\end{array}$ & Córrego & $\begin{array}{l}\text { Córrego } \\
\text { interm. }\end{array}$ & Lago & $\begin{array}{l}\text { Poço } \\
\text { Art. }\end{array}$ \\
\hline \multicolumn{8}{|l|}{ Exclusivo na propriedade } \\
\hline \multicolumn{8}{|l|}{ Utilidade na prop. - saúde } \\
\hline \multicolumn{8}{|l|}{ Utilidade na prop. - irrigação } \\
\hline \multicolumn{8}{|l|}{ Utilidade na prop.-animais domésticos } \\
\hline \multicolumn{8}{|l|}{ Lançamento de dejetos humano/animal } \\
\hline \multicolumn{8}{|l|}{ Utilizado por vizinhos } \\
\hline \multicolumn{8}{|l|}{ Cultura anual APP } \\
\hline \multicolumn{8}{|l|}{ Cultura perene APP } \\
\hline \multicolumn{8}{|l|}{ Compr. por erosão } \\
\hline \multicolumn{8}{|l|}{ Mata ciliar presente } \\
\hline \multicolumn{8}{|l|}{ Mata ciliar ausente } \\
\hline \multicolumn{8}{|l|}{ Mata ciliar parcialmente presente } \\
\hline \multicolumn{8}{|l|}{ APP com cerca } \\
\hline \multicolumn{8}{|l|}{ APP sem cerca } \\
\hline \multicolumn{8}{|l|}{ Veg. Nativa APP } \\
\hline \multicolumn{8}{|l|}{ Veg. Exótica APP } \\
\hline \multicolumn{8}{|l|}{ Mata ciliar presente - jusante } \\
\hline \multicolumn{8}{|l|}{ Mata ciliar presente - montante } \\
\hline \multicolumn{8}{|l|}{ Estrada acesso na APP } \\
\hline \multicolumn{8}{|l|}{ Adota práticas conservacionistas } \\
\hline \multicolumn{8}{|l|}{ TOTAL } \\
\hline Dados sobre Agricultura Familiar & Sim & Não & Quantos & Pecuária & Agricultura & Mista & $\begin{array}{l}\text { Apoio } \\
\text { técnico }\end{array}$ \\
\hline \multicolumn{8}{|l|}{ Mão obra exclusiva familiar } \\
\hline Mão obra contratada CLT/Diarista & & & & & & & \\
\hline
\end{tabular}




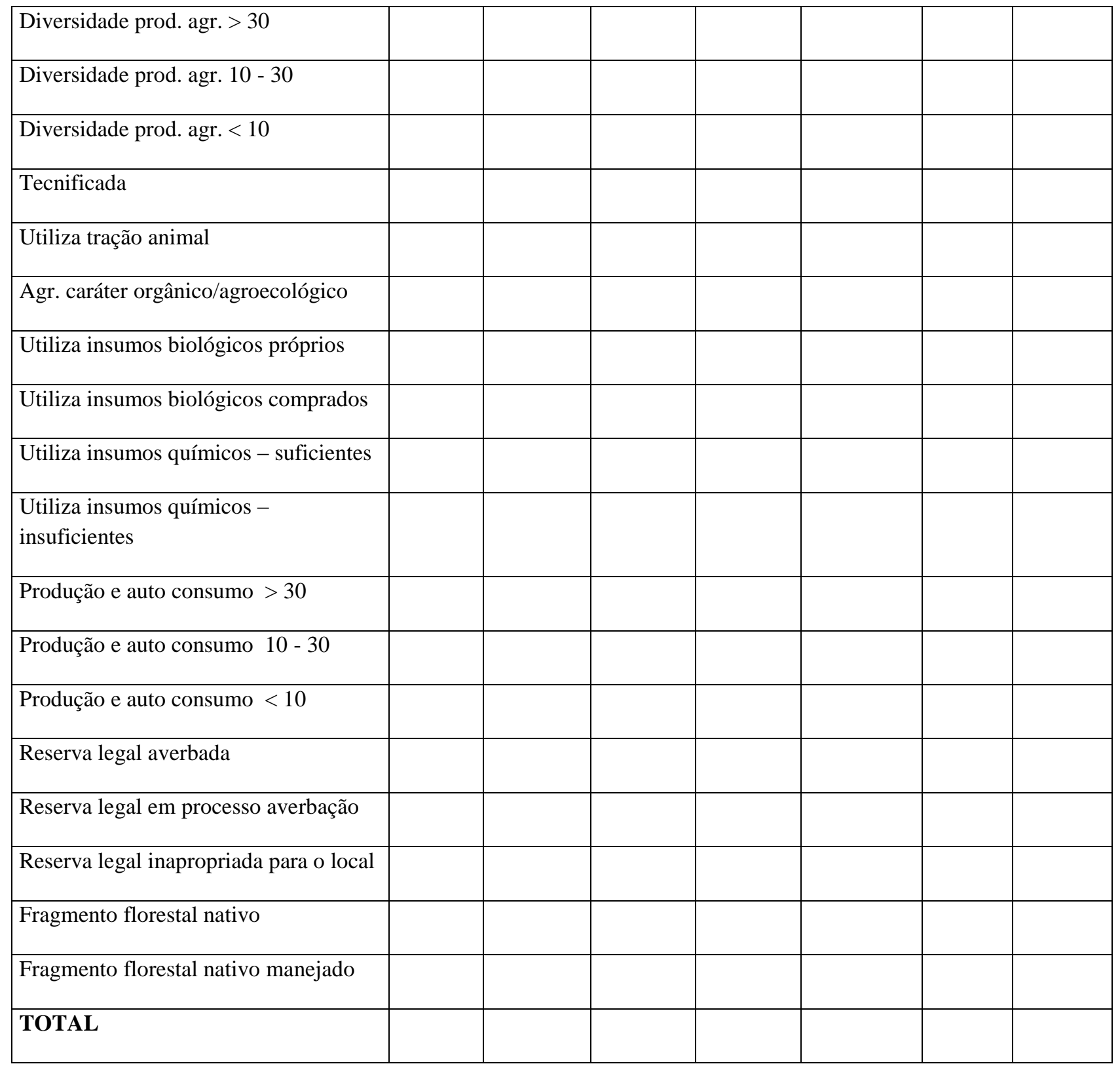

